\title{
ESTUdos SObre a redistribuição do enXOFre nO feIJOEIro (Dhaseolus oulgaris (L.) cV. Carioca)
}

$J \bigcirc \tilde{A} \bigcirc S \cup Z \cup K I$

Orientador: Luripedes Malavolta

Dissertação apresentada à Escola Superior de Agricultura "Luiz de Queiroz", da Universidade de São Paulo, para obtenção do título de Mestre em Solos e Nutrição de Plantas.

P I R A C I C A B A

Estado de São Paulo - Brasil

Setembro, 1980 
Grande è a ciência.

Grandes são os homens que a praticam.

Grande também deverá ser o amor e a humildade

presente em nossos corações, para cumprirmos

verdadeiramente a missão de todos nós.

Mas, grande realmente é DEUS, que se encontra acima

de tudo e de todos, e de cuja grandeza surgimos.

Que assim seja.

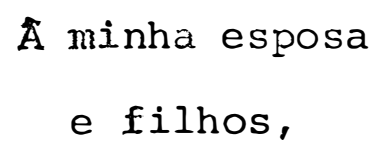

Dedico 


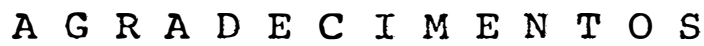

Ao Dr. Eurípedes Malavolta pela orientação segu ra e constante, durante o desenvolvimento do trabalho.

Ao Dr. Admar Cervellini, DD. Diretor do Centro de Enègla Nuclear na Agricultura, CENA - USP e, ao Dr. Aris teu Mendes Peixoto, DD. Diretor da E.S.A.. "Luiz de Queiroz"USP, Piracicaba, pela possibilidade oferecida.

Ao Dr. Ailto Antonio Casagrande e Dr. Wanderley José de Melo, DDs. Diretor e Vice-Diretor da Faculadade de Ciên cias Agrārias e Veterinārias "Campus" de Jaboticabal - UNESP, pelo apoio em todos os momentos.

Ao Dr. Virgỉlio Nascimento Filho e José Osório Bertoli pelas sugestões e colaboração nas operações de conta gens do material radioativo.

Ao Dr. André Louis Martin Neptune pela aquies cência e atenção dedicada durante as anālises de $\mathrm{S}-\mathrm{SO}_{4}{ }_{4}^{\prime}$ reali zada nos laboratórios da Seção de Fertilizantes e Fertìlidade do Solo AO CENA.

Ao colega Takashi Muraoka pelas sugestões e aten ção dedicada durante as análises de $\mathrm{S}-\mathrm{SO}_{4}=$

Aos docentes e demais funcionārios do Departa mento de Tecnologia da Faculdade de Ciências Agrärias e Vete rinārias "Campus" de Jaboticabal, nas pessoas de seu chefe 
Dr. Raul Roberto de Souza Faleiros e sub-chefe Drạ Maria Amá lia Brunini Kanesiro.

Ao colega Jorge Eimori pela colaboração nos tra balhos de estufa e laboratőrio.

Aos colegas Alfredo José F. Melo, Cleusa P. Ca bral, Domingos F. Filho, Godofredo C. Vitti, Isabel I. Eimo rí, Luiza H. I. Nakayama e demais funcionārios da seção de Nu彑 trição Mineral de Plantas do CENA, pela amizade e convỉvio.

A Sra. Luiza Maria Villanova pelo serviço de da tilografia.

Os mesmos agradecimentos são devides a todos que direta ou indiretamente contribuiram para o desenvolvimen to deste trabalho.

Um agradecimento especial é estendido à minha espôsa Vera Lūcia pelo apoio e dedicação sempre constantes.

Finalmente, acima de tudo, agradecimentos são devidos, principalmente, a Deus, por tudo quanto passamos e havernos ainda de passar, para a nossa evolução contỉnua atra vēs dos tempos. 
ESTUDOS SOBRE A REDISTRIBUIÇÃO DO ENXOFRE NO FEIJOEIRO (PhaseO lus vulgaris (L.I CV. Cariocal.

Autor:

Orientador:

Eng? Agro JOÃO SUZUKI Prof. Dr. EURIPEDES MALAVOLTA

RESUMO

Efetuou-se o estudo da redistribuição do $\mathrm{S}$ que fora absorvido pelo feijoeiro, em função do seu desenvolvimen to em soluções nutritivas completa e deficiente neste elemento.

Estas plantas, tiveram seu desenvolvimento ini cial em suas respectivas soluções nutritivas, todas contendo ${ }^{35} \mathrm{~s}$. Dentre estas, um grupo foi mantido nesta solução, para ab sorver ${ }^{35} \mathrm{~S}$, somente até a ëpoca de formação do ramo principal (estādio $\mathrm{E}_{\mathcal{I}}=24$ dias): outro grupo, atê a fase de máximo flo rescimento $\left(E_{2}=52\right.$ dias $)$ e finalmente um terceiro grupo, que se desenvolveu até o final do ciclo em solução radioativa $\left(E_{3}=\right.$ $=84$ diasl.

Em cada estādio, plantas internas foram colhidas para análises, determinando-se enxofre total e sulfato nas suas diferentes partes, bem como a respectiva radioatividade.

Em todos os tratamentos constatou-se a ocorrên cia da redistribuição do enxofre, cuja percentagem em relação ao total absorvido previamente, se apresentou maior em plantas 
deficientes, todavia, a quantidade total redistribuida foi maior para as plantas do tratamento completo. As folhas se apresentaram como os principais órgãos envolvidos na redistri buição do enxofre.

Ainda, os dados obtidos sugerem ser o s-sulfato, a forma utilizada para tais redistribuições. 
STUDIES ON THE REDISTRIBUTION OF SULPHUR IN THE BEAN PLANT (Phaseolus vulgaris L., var. Carioca)

Author:

Engo Agro JOÃo SUZUKI
Adviser :

Prof. Dr, EURIPEDES MALAVOLTA

SUMMARY

This paper deals with the results of an experi mental designed to study the redistribution of radioactive sul phur previously taken up the bean plant grown in full strenght and sulphur deficient nutrient solution.

AIl plants initially received labelled $\left({ }^{35}\right)$ in the substrate. Afterwards a group of plants was kept in the presence of the tracer until the main stem developed (stage $\mathbb{I}_{1}$ $=24$ daysl; a second group received radioactive sulphur until the period of full blooming $\left(E_{2}=52\right.$ days $)$; a third group, fi nally, was kept in the presence of radiosulphur till maturity of the pods $\left(E_{3}=84\right.$ days $)$.

In each stage plants were collected for analysis, total and sulphate sulphur being determined in their organs, as well as the corresponding radioactivity.

Redistribution of the labelled sulphur was obser ved in all cases. S-deficient plants showed a higher degree of redistribution on a percentage basis of the previously cumula 
ted; in absolute terms, however, the phenomenon was more mar ked in the non deficient plants. Leaves were the most important reservoir of sulphur for redistribution.

Evidence is presented which suggests that sul phate-s is the form used for redistribution. 
2. REVIST̃O DE IITERATURA $\ldots \ldots \ldots \ldots \ldots \ldots \ldots \ldots$

3. MAterial e metodos $\ldots \ldots \ldots \ldots \ldots \ldots \ldots \ldots \ldots \ldots$

3.1. Material $\ldots \ldots \ldots \ldots \ldots \ldots \ldots \ldots \ldots$

3.2. Mêtodos $\ldots \ldots \ldots \ldots \ldots \ldots \ldots \ldots \ldots \ldots . \ldots . \ldots 14$

3.2.1. Ensaio Preliminar ........... 14

3.2.2. Ensaio Definitivo $\ldots \ldots \ldots \ldots, 17$

4. RESULtADOS E DISCUSSÃO $\ldots \ldots \ldots \ldots \ldots \ldots \ldots . \ldots . \ldots . \ldots$

4.1. Ensaio Preliminar $\ldots \ldots \ldots \ldots \ldots \ldots . \ldots 24$

4.2. Ensaio Definitivo $\ldots \ldots \ldots \ldots \ldots \ldots . \ldots 28$

5. CONCLUSÕES $\ldots \ldots \ldots \ldots \ldots \ldots \ldots \ldots \ldots \ldots \ldots$

6. LITERATURA CITADA $\ldots \ldots \ldots \ldots \ldots \ldots \ldots \ldots \ldots$ 
1. INTRODUÇÃO

O enxofre è um elemento constituinte de um gran de número de compostos das plantas. Destacam-se entre estes, os aminoácidos, metionina e cistina, encontrados tanto na for ma livre como na constituição das proteỉnas vegetais e que re presentam elevada importância na nutrição JORDAN e ESMINGER (1958).

No Brasil, a fonte mais importante de proteinas vegetais para a alimentação de toda a população é considerada como sendo o feijão, e seu cultivo é generalizado por todo o territôrio nacional MALAVOLTA (1971). I'odavia, trata-se de uma cultura conduzida num sistema rudimentar de agricultura, apresentando sempre uma baixa produtividade, sendo atribuido como causa principal a falta de adubação adequada ALMEIDA et álii (1972). Devido à sua grande importância, inúmeras pesqui sas sobre a nutrição do feijoeiro tem sido efetuadas, princí palmente com respeito aos macronutrientes, contudo, sem obter resultados muito consistentes MALAVOLTA (1971). De certo mo 
do, tão importante quanto uma maior produtividade è 0 nỉvel da qualidade nutricional do feijão produzido, no qual, a pa ticipação do enxofre nas suas diversas formas torna-se bastan te evidente PORTER et alii (1974) e EPPENDORFER (1971).

Absorvido predominantemente pelas plantas na for ma de sulfato, o enxofre ê rapidamente incorporado na sua for ma reduzida e cuja importância, sob certos aspectos, apresen ta-se comparävel ao do nitrato absorvido WILSON (1962). Den tro da planta o enxofre é considerado como elemento de trans locação média, tendọ sido observado em inúmeros trabalhos uma tendência do mesmo em migrar para partes ainda em formação, principalmente na época de floração e desenvolvimento das se mentes que por sua vez acumula maior percentual de enxofre, GALLO e MYASAKA (1961). Nesta mesma época, ou seja, aos 40-50 dias após a semeadura observa-se uma queda brusca no teor percentual do enxofre foliar NETTO et alii (i97i). Embora, tal fato ocorra como função da diluição do elemento na planta por coincidir com um periodo de grande aumento de matëria se ca, por outro lado, deve-se considerar tambëm que esta ẻ uma ëpoca de maior absorção de enxofre pelo feijoeiro, sendo de 12,6 a 98,6\% do total entre 30-50 dias apōs a semeadura (HAAG et alii, 1967). Esta diminuição no teor foliar, torna-se mais evidente, quando a cultura é conduzida em nỉveis deficientes de enxofre GALLO e MYASAKA (1961). Tal fato, tambēm jā fora observado por WOOD (1942). Deste modo, torna-se bastante pro vảvel que uma parcela do enxofre existente nas partes mais jo 
vens, flores e sementes seja proveniente de folhas mais ve lhas. Se esta translocação ocorre, devem existir uma ou mais formas predominantes pelas quais o enxofre migra atravês de cêlulas e tecidos e para as diferentes partes dentro da plan ta. Assim, com o objetivo de tentar constatar a ocorrência des ta redistribuição e atê que ponto a mesma pode ser influencia da quando as plantas se desenvolvem em meio deficiente neste elemento, bem como a forma em que o mesmo se transloca, foi conduzido o presente ensaio. 
2. REVISÃO DE IITERATURA

o enxofre tem sido estudado desce a década de 1930, em sua ligação com o metabolismo vegetal KILYN (1953).

Este elemento ê absorvido pelas raizes quase ex clusivamente na forma de ion sulfato, embora tenha sido com provado tambèm a absorção na forma de aninoácidos metionina e cistina (BLAIR, 1971).

Uma outra forma de enxofre é absorvida pelas fo Ihas das plantas, como sendo na forma de $\mathrm{SO}_{2}$ aplicado por fu migação HARRISON et alii (1944) e THOMAS et alii (1944a). Ain da, segundo JORDAN e ENSMINGER (1958), o $\mathrm{SO}_{2}$ pode penetrar dí retamente atravēs dos estomatos abertos, mas, a quantidade absorvida por este meio não chega a ser suficiente para suprir as necessidades da maioria das plantas. Esta ủltima forma de enxofre quando fornecida em quantidades excessivas chega a provocar danos nas folhas, causado pelo acúmulo de sulfeto que atinge nível tóxico quando se aplica $\mathrm{SO}_{2}$ em alta concentração por curto espaço de tempo, ou então pelo acúmulo excessivo de 
sulfato, que ocorre quando se expõe a planta por longo tempo em concentração subletal de $\mathrm{SO}_{2}$ LINZON (1972) e ZIEGLER (1975). Em algumas culturas o enxofre também pode ser provido atravês de inseticidas e fungicidas JORDAN e ESMINGER (1958).

Absorvido pelas plantas, inicia-se rapidamente a redụção assimilatória do enxofre, tendo sido detectado enxo fre na forma $\left({ }^{35}\right.$ S orgânica) em folhas de diversas culturas que haviam absorvido radiosulfato, cujo tempo, varia entre 1-5 horas dependendo da cultura THOMAs et alii (1944b). Em al fafa tambểm foi observado grande rapidez na conversão de en xofre inorgânico a orgânico THOMAS et alii (1950).

$E$ de se notar que embora o metabolismo sulfata do apresente importância comparävel ao metabolismo dos outros elementos como N, P e C existe uma grande defazagem em termo de estâgio de conhecimento. THOMPSON (1967) atribui como cau sa provável a instabilidade dos compostos de enxofre, causada pela capacidade de existì em estados de valência variando desde o alto valor de $(+6 L$ à até $(-2)$, e que permite a ocor rência do $\mathrm{S}$ em amplas combinações, produzindo uma multiplici. dade de compostos e de fácil interconversão entre si, o que dificulta muito o estudo do seu metabolismo.

Por outro lado, inúmeros compostos sulfurados existem por toda a planta, e que desempenham funções em gran de parte jä definidas.

Assim, tem-se os aminoácidos sulfurados, cistí na, cisteîna e metionina que contēm os grupos dissulfetos (S- 
-S), Sulfidril $(\mathrm{S}-\mathrm{H})$ e tioeter $\left(\mathrm{S}-\mathrm{CH}_{3}\right)$ e que desempenham im portante função estrutural e funcional das proteỉnas ALLAWAY e THOMPSON (1966).

Os grupos sulfidril livres, encontrados nas glu tationas e cisteinas, estão envolvidos no mecanismo de ma nutenção do potencial de oxidação-redução das cēlulas LOUGH MAN (1964). As glutationas são ativadoras da enzima glioxila se que converte metil glioxal à ācido läctico (BLAIR, 197l).

Ligado ao crescimento das plantas encontram-se os reguladores de crescimento biotina e tiamina que contem en xofre na sua constituição JORDAN e ESMINGER (1958), sendo que a relação enxofre, vitaminas, tiamina e biotina apresen tam caracteristicas essenciais para o metabolismo vegetal GILBERT (1951).: Segundo este mesmo autor, e EATON (1951), o enxofre ocorre ainda na forma volätil, tais como óleo de mos tarda, alil e vinil sulfeto e mercaptanas. A maioria destes compostos estão limitados a certas famỉlias de plantas e mui to pouco conhecidos com respeito à sua significância para as plantas e para os animais que o ingerem.

Em leguminosas, segundo WOOD (1942) alēm das

formas normais de enxofre existem as formas especiais, predo minando sulfato etéreo.

As formas inorgânicas de enxofre em plantas ocor rem principalmente na forma de sulfatos, sendo que aproximada mente 65\% se encontram nessa forma GILBERT (1951). o teor de enxofre total nas plantas, varia de 
planta para planta de acordo com o gênero e em alguns casos, este teor chega a ser maior do que para Ca, P e Mg. Nas plan tas da familìa brassicâceas este teor ê tão elevado, que são chamados de transportadoras de enxofre GILBERT (1951).

Em feijoeiro, observa-se um teor de $\mathrm{S}$ acima do teor de P, característica esta apresentada tambêm por outras culturas de grande interesse econômico tais como algodão, ca na de açúcar e arroz MALAVOLta (1952).

A distribuição deste elemento nas plantas apre senta características mais ou menos normais, como sendo, maior percentual nas folhas, seguido pela semente, caule e raiz. De um modo gexal, maior teor de $S$ é encontrado em teciảos velhos - que ể evidenciado pelo amarelecimento das partes mais jo. vens quando manifestam sintomas de deficiências Peterson (1914) citado por GILBERT (1951). O teor de s-total em plantas de cevada e trigo, cultivadas em solução nutritiva, recebendo enxofre na forma de $\mathrm{Na}_{2}^{35} \mathrm{SO}_{4}$ via radicular e fumigação $\mathrm{com} \mathrm{SO}_{2}$ apresentou maior concentração no topo do que nas raizes. Por outro lado, observou-se um maior teor em folhas adultas, se guido de folhas velhas, jovens e senescentes. Quanto às for mas de $S$ encontradas nas diversas partes foram: em folhas, predominarm formas orgânicas solúveis e insolîveis em ácido, embora tenha apresentado tambēm quantias apreciāveis de sulfa to e S-lábil. Nas outras partes, predominam, caule-sulfato; . y. zes-fração insolúvel em ácido e no miolo-s-lābil e fração solủvel em ácido thOMAs et alii (1944b). 
Uma outra classe de composto sulfurado em plan tas, tem merecido especial atenção, como sendo os sulfolipî deos, que geralmente ocorrem em tecidos celulares capazes de realizar fotossintese BENSON (1963).

KYLIN (1966) observou em cêlulas de Scenedesmus um aumento na incorporação de $s$ a partir de uma solução de sulfato quando em presença da luz, principalmente na forma de sulfolipìdeos. Este efeito da luz, foi aumentado quando em presença de $\mathrm{CO}_{2}$ e nitrogênio. Segundo TERRY (1976), os cloro plastos contem proteînas ricas em enxofre sendo a moxfologia dos mesmos, muito afetada pela deficiência. Todavia, os efei. tos desta carência sobre a fotossintese são bastante confli tantes existindo casos em que a mesma aumenta e diminui com a deficiência de S. HARWOOD e NICHOLLS (1979), mostram pela ex posição e discussão de inümeros trabalhos de diferentes auto res, uma correlação bastante direta dos sulfolipỉaeos com os mecanismos fotossintēticos.

Esta participação do $S$ na constituição prorêica dos cloroplastos já havia sido observado por WOOD (1942), sen do que o efeito do enxofre sobrr teor de clorofila já fora questionado desde a dêcada de 20 por Miller (1919), citado por GILBERT (19.5I) e THOMAS et alii (1950).

o composto sulfatado, responsável pelo sabor de certos alimentos, conhecido como dimetil-sulfito e já detecta do em tomate, milho doce e chā, recentemente foi detectado em cacau e contribui para o aroma caracteristico do chocolate, 
tendo como provāvel percursor a metil-s-metionina LOPEZ e QUESNEL (1976).

Como se observa, o enxofre é distribuido em inû́ meras formas por todas as partes da planta, o que sugere in tensa translocação, embora em termos de mobilidade dentro da planta esteja classificado segundo LAUCHLI (1972) como elemen to de médìa translocação.

Desde o contato do enxofxe com os pelos radicu lares de uma planta, iniciamse o processo de absorção e trans porte deste elemento que o colocarā nas diversas partes da planta onde for exigido.

Em plantas de girassol, os sulfatos absorvidos radicularmente parecem ser controlados metabolicamente, uma vez que tem sido observado uma retenção deste ion pelas raí zes independentemente da intensidade de transpiração, enquan to para o sulfato transportado para os brotos, observou...se uma relação direta de ion com a ãgua absorvida PETTERSON (1960).

Mesmo quando submetido a variação da pressão ne gativa de 0 a $500 \mathrm{~mm}$ de Hg através de uma bomba de vãcuo adap tado ao caule de girassol, constatou-se a retenção do sulfato marcado pela raiz. Este suliato retido, que foi quantificado, trata-se daquele que restou apōs a lavagem das raỉzes em solu Ção nutritiva inativa, durante 5 minutos, sendo considerado como o sulfato retido metabolicamente por deträs de alguma barreira ou camada de difusão PETTERSON (1966b). Semelhante 
fato, coincide com o observado por PETTERSON (1960 e 1966a) em que o fluxo de água atravês da planta, não interfere com a tạ xa de aumento do componente sulfato retido pela raíz.

Ainda, segundo PETTERSON (1966b) sob a ação do 2,4 dinitrofenol (inibidor do processo ativo de absorção e causador do truncamento da fosforilação respiratöria), ocorreu uma grande diminuição na fração de sulfato retido pelas raỉzes, o que confirma realmente que a retenção do sulfato ocorre por um processo metabölico ativo.

O fenômeno dà retenção pelas raỉzes, pelo qual passa o sulfato, mostra uma participação direta nos processos de absorção e transporte dentro do simplasto. como se fosse um trabalho para manter uma concentração constante de sulfato, independentemente da taxa de transporte da solução para o bro to PETTERSON (1966a).

O nutriente, uma vez absorvido pela raỉz, serā levado via xilema até as folhas. Estas folhas, não só receberm ions do xilema, como tambển são capazes de enviar ions atra vês do Eloema. O balanço entxe a importação e exportação ioni ca, depende do estädio de desenvolvimento da planta. A inten sidade desta movimentação de ions depende da mobilidade do mes mo no floema, sendo que o enxofre e alguns micronutrientes são considerados como intermediârios LAUCHLI (1972).

Segundo THOMAS et alii (1944a) a translocação do $s$ ocorre como ion sulfato quando se move ao longo do caule para o ápice como no sentido inverso. TOLBERT e WIEBE 
não conseguiram descobrir formas orgânicas de $\mathrm{S}$ na seiva do xilema de Hordeum vulgare (cevada), spinacea oleracea (espina fre) e Cucumis sativus (pepino).

Em diversas partes da planta, foi possîvel evi denciar que o s-orgânico nas folhas foi transformado em S-inor gânico antes de ser translocado, e logo em seguida voltando para a forma orgânica nas raỉzes e grãos THOMAS et alii (1944a).

Estas translocações foliares são marcantes, so mente quando hâ uma necessidade de sintese râpida e uma rela tiva deficiência de absorção. Em outras situações o ion sulfá to é relativamente imôvel nas folhas de diferentes culturas e o enxofre necessărio é transportado das raizes para as áreas onde for requerido (WOOD, 1942).

Por outro lado, segundo BIDDULPH et alii (1956) existe uma fração do enxofre total dentro da planta que permanece môvel e que se movimenta livremente de um örgão para ou tro. BOUMA (1967) observou em plantas de trevo, que se desen volveram em solução nutritiva radioativa $\left({ }^{35} \mathrm{~S}\right)$ com nỉveis de $0,25,1,0$ e 4 ppm de $S$, que à medida que se aumentava os ni veis de $S$, tambëm aumentava a mobilidade do ${ }^{35} \mathrm{~S}$. O autor suge re que uma parte do $S$ que chega às folhas é incorporado em compostos estruturai.s e que representam fontes inacessiveis de $S$ para redistribuição aos outros órgãos. Foi observado tam bêm que a falta de enxofre aumentou a necessidade de $\mathrm{S}$ nas fo thas novas em crescimento. Segundo o autor, a concentração do S na solução nutritiva determina alterações na translocação 
do $S$ em plantas, sendo esta a causa principal do conflito en tre autores.

A translocação do enxofre em plantas, parece so frer influências de alguns fatores como temperatura, inclusi ve chegando-se a obter para o caso da aveia uma temperatura adequada para maior crescimento e absorção de enxofre, como sendo $27 / 22^{\circ} \mathrm{C}$ (dia/noite) (BLAIR, 1970).

De acordo com WIEBE e WIRHEIM (1962), qualquer condição que provoque tensão de umidade e murchamento da plan ta provoca diminuição na translocação devido à falta de turge cência necessāria para o desempenho da célula ocorrendo dimi nuiç̧ão da fotossîntese e do crescimento.

INGELSTEN (1966) estudou em plantas de trigo, o efeito da plasmólise e não plasmólise causado por dosagens controladas de manitol na raiz, verificando diminuição da trans locação do sulfato para o caule, quando sob concentração de manitol, suficiente para causar plasmólise. 
3. MATERIAL E METODOS

\subsection{Material}

Conảuziu-"se o ensaio em casa de vegetação, utí lizando-ase solução nutritiva en recipientes de plāstico com capacidade para 2,5 litros, revestidos externamente com tinta aluminizada.

As sementes utijizadas foram de feijoeiro Pha seolus vulgaris (I.) cv. Carioca, devidamente tratadas e arma zenadas em câmara com umidade e temperatura adequadas, sendo que as caracteristicas da semente se encontram na Tabela 1 .

o enxofre utilizado como elemento marcador foi o radioisôtopo ${ }^{35} \mathrm{~S}$ na forma de $\mathrm{Na}_{2}{ }^{35} \mathrm{SO}_{4}$, livre de carregado res, produzido no Instituto de Energia Atômica (I.E.A.) S.P., sendo recebido uma atividade de $5 \mathrm{mCi}$ em $1 \mathrm{ml}$. 
Tabela 1 - Caracterîsticas da semente* de feijoeiro Phaseolus vulgaris (L.) cv. Carioca.

\begin{tabular}{ll}
\hline \multicolumn{1}{c}{ Discriminação } & Valor \\
\hline Porcentagem de germinação apresentada & $94 \%$ \\
Indice de pureza genētica & $99,6 \%$ \\
Nümero do Lote & 2 \\
Origem - EPAMIG (Minas Gerais) & \\
\hline
\end{tabular}

(*) Sementes cedidas pela secção de Radiogenética do Centro de Energia Nuclear na Agricultura (CENA), USP. Piracicaba, S.P.

3.2. Mêtodos

3.2.1. Ensaio Preliminar

Diante da necessidade de se cultivar plantas de feijoeiro em solução nutritiva completa e solução com der̃iciên cia em S, durante o ciclo completo, tornoumse necessário a condução de um ensaio preliminar, visando determinar uma con centração de enxofre $\left(\mathrm{S}-\mathrm{SO}_{4}^{\bar{N}}\right)$ na solução nutritiva, que fosse minima a ponto de provocar sintomas visuais de deficiência na planta, porém, suficiente para que a planta se desenvolvesse até o final do ciclo. 
3.2.1.1. Obtenção das mudas

Com este objetivo, sementes de feijoeiro Phaseo Zus vulgaris (L.I CV. Carioca, foram colocadas para germinar em bandejas contendo vermiculita mantidas úmidas com solução de $\mathrm{Ca} \mathrm{SO}_{4} 10^{-4} \mathrm{M}$., ficando as mesmas ao abrigo da luz direta, a.tê que as plântulas atingissem 2 a $3 \mathrm{~cm}$ de altura. Quando alcançaram aproximadamente $10 \mathrm{~cm}$ de altura, foram colocadas durante uma semana para desenvolvimento inicial em solução nu tritiva completa (macro e micronutrientes) preparada segundo Hoagland e Arnon (1950) modificado por MALAVOLTA (1975) e di luỉdas com ãgua destilada na proporção 1:5, sendo mantidas com aeração contĩnua.

A seguir, plantas selecionadas pelo aspecto ve getativo foram transferidas para recipientes de plástico con tendo 2,5 1 de solução nutritiva preparada de acordo com os diferentes tratamentos. Foram destinados 1 planta para cada recipiente.

\subsubsection{Solução nutritiva}

\footnotetext{
A solução nutritiva para o desenvolvimento defi. nitivo foi obtida segundo os padrões estabelecidos para o pre paro da solução sem enxofre MALAVOLTA (1975) sendo o enxofre adicionado na forma de $\mathrm{Na} \mathrm{SO}_{4}$ nas proporções de 0,$0 ; 0,1$; 0,5; 1,0 e 2,0 milimoles de $\mathrm{s}$ por litro de solução.
} 


\subsubsection{Delineamento estatistico e tratamentos}

O delineamento estatîstico empregado foi o intei ramente casualizado com 4 repetições para cada tratamento, que são representados pelas 5 diferentes concentrações de $\mathrm{S}$ nas so luções nutritivas, totalizando 5 tratamentos.

3.2.1.4. Condução do ensaio

Durante a condução do ensaio foram efetuadas, principalmente, observações quanto ao aparecimento de sintomas das deficiências de enxofre, representado pelo amarelecimento uniforme do limbo foliar de folhas jovens, alëm de outras ca racteristicas como desenvolvimento radicular e da parte aérea exposta, bem como o controle fitossanitário das plantas. As so luções nutritivas foram renovadas completamente a cada vinte dias, sendo mantidas com aeração forçada durante todo o ensaio.

Aos 47 dias, época em que as plantas iniciavam a formação de vagens, coletaram-se as plantas inteiras, separan do-as em raiz, caule + ramos, folhas e flores + vagens.

3.2.1.5. Preparo das amostras e anâlise química

As diferentes partes das plantas, foram coloca das para secagem em estufas a $70^{\circ} \mathrm{C}$ até peso constante, sendo pesadas e moỉdas em macro e micro moinho, obtendo-se a matëria 
seca que foi adicionada em sacos plásticos para posterior anâ lise quỉmica, determinando-se para todos os órgãos da planta os teores de s-total, segundo o mêtodo turbidimêtrico proposto por TABATABAI e BREMNER (1970).

\subsubsection{Ensaio definitivo}

Baseados no ensaio preliminar, definiu-se a con centração adequada de $s$ para a solução nutritiva com deficiên cia de enxofre, como sendo de 0,05 milimoles de $\mathrm{s}$ por litro de solução.

\subsubsection{Obtenção das mudas}

Para o ensaio em fase definitiva, procedeu-se de modo anâlogo ao descrito anteriormente, omitindo-se apenas a fase de manutenção por uma semana em solução nutritiva para crescimento inicial, sendo que nesta etapa, as plantas foram diretamente transplantadas para a solução nutritiva de traba tho.

\subsubsection{Solução nutritiva}

Em princípio, a solução aqui empregada foi basi camente a mesma do ensaio preliminar, somente a concentração de enxofre sofreu alterações, sendo adicionadas à solução nutrití 
va completa e solução com deficiência em $\mathrm{S}, 2,0$ e 0,05 milimo les de $S$ por litro de solução, como $\mathrm{Na}_{2} \mathrm{SO}_{4}$, respectivamente. Outra alteração, foi a adição de $20 \mu \mathrm{Ci}$ de ${ }^{35} \mathrm{~S}$ como $\mathrm{Na}_{2}{ }^{35} \mathrm{SO}_{4}$ em cada vaso contendo 2,51 de solução nutritiva, constituindo a solução codificada como solução $S+S^{*}$. A solução $S-S^{*}$, repre senta aquela na qual não foì adicionado $\left({ }^{35} \mathrm{~S}\right)$.

Obs. A solução $S+S^{*}$, quando renovada, recebeu igualmente 20 uci de ${ }^{35}$ s/vaso.

3.2.2.3. Tratamentos e delineamento estatístico

O presente ensaio, constou de 6 tratamentos prin cipais com 4 repetições. Os tratamentos I, II e III referem-se às plantas cultivadas em solução nutritiva completa.

a) Tratamento I, refere-se às plantas que foram cultivadas em solução $S+S^{*}$ até os primeiros 24 dias após emer gência que è justamente a êpoca de emissão do ramo principal diferenciado e foi chamado de 10 estádio de desenvolvimento. De pois deste período, estas plantas passaram a se desenvolver em solução $S$ - S* até o final do ciclo vegetativo.

b) Tratamento II, refere-se às plantas que foram cultivadas em solução $s+S^{*}$ até os primeiros 52 dias apỏs a emergência que è justamente a época de máximo florescimento e foi chamado de 29 estädio de desenvolvimento. Depois deste pe rỉodo, estas plantas passaram a se desenvolver em solução S - S*, atê o final do ciclo vegetativo. 
c) Tratamento III, refere-se às plantas que fo ram cultivadas em solução $S+S^{*}$ até o final do ciclo vegetati vo e que foi chamado de 39 estádio de desenvolvimento.

Os 3 tratamentos restantes IV, V e VI, referem-se às plantas cultivadas em solução nutritiva com deficiência em enxofre. Para estes tratamentos IV, V e VI, aplicou-se o mesmo procedimento jả descrito para os tratamentos I, II e III respectivamente. O delineamento estatĩstico empregado, foi o inteiramente casualizado.

\subsubsection{Condução do ensaio e amostragens}

Na condução do enșio foram feitas observações semelhantes às do ensaio preliminar, apresentando modificações no tocante à época da remoção completa das soluções nutritivas, que foi feita em conjunto com as amostragens. Para a mudança das plantas da solução $S+S^{*}$ para $S-S^{*}$, efetuada para os tratamentos I e IV no primeiro estädio e para os tratamentos II e $V$ no segundo estádio, procedeu-se de maneira semelhante, como sento a lavagem das raỉzes em āgua destilada corrente, de modo a retirar quaisquer vestỉgios da solução $S+S$ * anterior . Ainda, estas plantas foram individualmente marcadas de modo a tornar possivel a delimitação entre as partes desenvolvidas em solução $S+S^{*}$ e as partes desenvolvidas após a mudança para solução $S$ - S*, possibilitando assim a sua separação, quando das amostragens nas épocas seguintes. 
As amostragens foram feitas colhendo-se a planta inteìra separando-a em seus órgãos raiz ( $R$ ), caule + ramos ( $C+$ $+r$ l, folhas (fl, flores (fll e frutos, que por sua vez foram separados em grãos ( $g$ ) e pericarpo (p). O mesmo critério de se paração foì adotado tambēm para solução $S$ - $S^{*}$. Para evitar uma possîvel contaminação das partes formadas quando da sua permanência em solução $S+S^{*}, \operatorname{com}$ a restante formada após a troca para solução $S-S^{*}$, adotou-se como critẻrio de amostra gens destas plantas, a colheita em primeiro lugar, da porção desenvolvỉa após a mudança para solução $S-S^{*}$, realizando a separação das suas partes em local limpo e isolado da ârea ex perimental, inclusive realizando a sua secagem até peso cons tante em estufa a $70^{\circ} \mathrm{C}$, tambérn em separado das demais amostras.

A matêria seca obtida, foi pesada e acondiciona da em sacos de polietileno para posterior anälise. Nas Figuras 1 e 2, são apresentados de forma esquemática o que foi descrí to neste item.

3.2.2.5. Anâlises quỉmicas

Na matêria seca obtida determinou-se os teores de S-total por turbidimetria segundo TABATABAI e BREMNER (1970), S-SO $=$ pelo método do azul de metileno proposto por JOHNSON e NISHITA (1952) utilizando-se a bateria de digestores-destiladores do Setor de Fertilizantes e Fertilidade do Solo do CENA e o s-orgânico estimado pela diferença entre s-total e ${\mathrm{S}-\mathrm{SO}_{4}}_{4}^{=}$. 


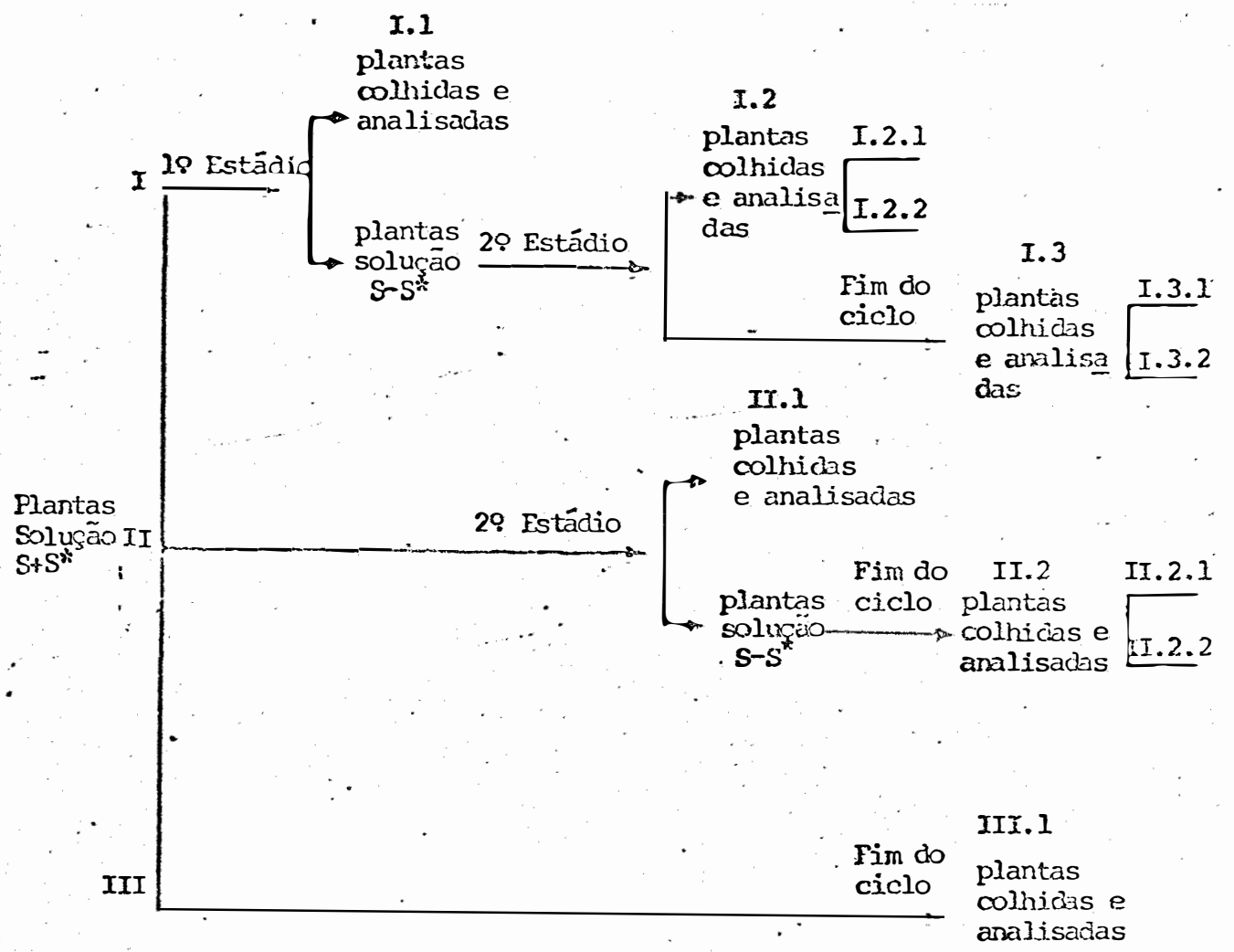

I, II e III = tratamentos básicos.

I.X.y; II.x.y e III.x = Tratamentos complementares, onde $(x)=$ a ordem numeral cardinal da amostragem $e(y)=$ a divisão de uma mesma planta, separando as partes (1) desenvolvidas em - solução $S+S^{*}$ e (2) desenvolvidas em solução $S-S^{*}$.

Figura 1 - Esquema dos tratamentos e da condução do ensaio ví sando o estudo da absorção e redistribuição do $S$ em feijoeiro $P$. vulgaris (L.) cv. Carioca cultivado em solução nutritiva completa. 


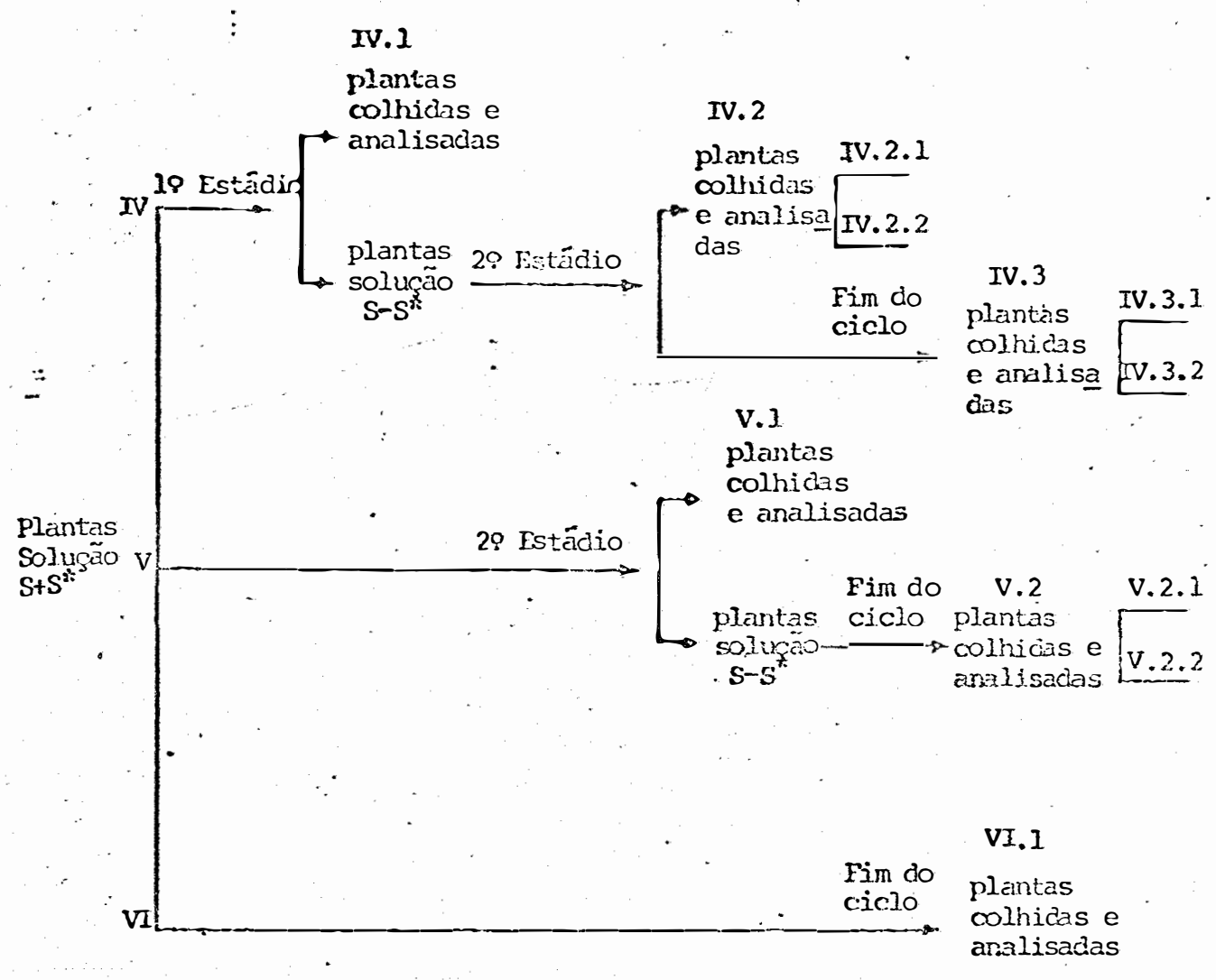

IV, $V$ e $V I=$ tratamentos bàsicos.

IV.X.y; V.x.y e VI.x = tratamentos complementares, onde $(\mathrm{x})=$ ordem nu meral cardinal da amostragem e $(y)=$ divisão de uma mes ma planta, separando as partes (1) desenvolvidas na solu ção $S+S^{*}$ e (2) desenvolvidas na solução $S-S^{*}$.

Figura 2 - Esquema dos tratamentos e da condução do ensaio ví sando o estudo da absorção e redistribuição do $s$ em feijoeiro $P$, vulgaris (I.) CV. Carioca cultivado em solução nutritiva com deficiência de enxofre. 
As contagens do ${ }^{35} \mathrm{~S}$ foram feitas no extrato obti do para s-total, utilizando-se o cintilador líquido Beckman Mod LS-230, do Setor de Radiologia do CENA. A solução cintila dora foi preparada segundo PATTERSON e GREENE (1965) e a corre ção para amostras que apresentaram efeito "nuenching" de cor foì efetuada pelo mêtodo do padrão interno, segundo : STUBS (1973). A fim de se evitar problemas com o decaimento da ativí dade do ${ }^{35} \mathrm{~S}$ em função do tempo, as contagens foram efetuadas apôs o têrmino do ensaio, na mesma época para todas as amos tras, facilitando a comparação entre os diversos tratamentos. 


\section{RESULTADOS E DISCUSSÃO}

4.1. Ensaio Preliminar

Os resultados obtidos para a produção de matēria seca e os teores de $\mathrm{s}$-total nas diferentes partes da planta do feijoeiro se encontram nas Tabelas 10 e 11 respectivamente, cu jas médias se apresentam nas Tabelas 2 e 3 .

Observa-se pela Tabela 2 , que a produção de matẹ rìa seca dos diferentes órgãos do fejjoeiro, não aumentaram proporcìonalmente com o aumento da concentração de $S$, mas que a matéria seca total produzida foi maior para a máxima concen tração de $\mathrm{S}$.

Quanto ao teor de S-total, observa-se pela Tabe la 3, que as plantas que se desenvolveram nạs concentrações de 0,0 e 0,1 milimoles de $\mathrm{S}$ por litro de solução, apresentaram em seus örgãos, teores bem próximos de $\mathrm{S}$ e que por sua vez, de um modo geral, se diferenciavam significativamente das plantas que se desenvolveram nas concentrações de $0,5,1,0$ e 2,0 milimo les, sendo que estes 3 últimos tratamentos apresentaram valo 
TABELA 2 - Médias da produção de matêria seca de feijoeiro cul tivado em solução nutritiva com concentrações cres centes de $\mathrm{s}$, colhido na época inicial de formação de vagens (47 dias).

\begin{tabular}{cccccc}
\hline \multirow{2}{*}{$\begin{array}{c}\text { Milimoles } \\
\text { de S/litro }\end{array}$} & \multicolumn{5}{c}{ Partes da Planta $(\mathrm{g}) \mathrm{a} /$} \\
\cline { 2 - 6 } 0,0 & $3,82 \mathrm{a}$ & $6,12 \mathrm{a}$ & $8,00 \mathrm{a}$ & $0,74 \mathrm{bc}$ & 18,68 \\
0,1 & $3,68 \mathrm{ab}$ & $10,48 \mathrm{~b}$ & $9,41 \mathrm{a}$ & $1,18 \mathrm{ac}$ & 24,75 \\
0,5 & $3,05 \mathrm{bc}$ & $7,91 \mathrm{ab}$ & $11,06 \mathrm{a}$ & $1,13 \mathrm{bc}$ & 23,12 \\
1,0 & $2,92 \mathrm{c}$ & $7,07 \mathrm{ab}$ & $9,49 \mathrm{a}$ & $0,98 \mathrm{bc}$ & 20,46 \\
2,0 & $3,30 \mathrm{abc}$ & $9,79 \mathrm{ab}$ & $11,45 \mathrm{a}$ & $1,62 \mathrm{a}$ & 26,10 \\
\hline Tukey $(5 \%)$ & 0,75 & 4,13 & 4,00 & 0,45 & fotal \\
F & 5,13 & 3,75 & 2,30 & 9,92 & \\
C.V. & 10,27 & 22,84 & 18,55 & 18,32 \\
\hline
\end{tabular}

a/ Mẻdias de 4 repetições. 
Tabela 3 - Médias dos teores de S-total na matéria seca de feí joeiro cultivado em solução nutritiva com concentra ções crescentes de $S$, colhido na êpoca inicial da formação de vagens (47 dias).

\begin{tabular}{ccccc}
\hline $\begin{array}{c}\mathrm{S}-\mathrm{Na}_{2} \mathrm{SO}_{4} \\
\text { Milimoles } \\
\text { de s/litro }\end{array}$ & \multicolumn{3}{c}{ Partes da planta $($ S-total $\%$ ) } \\
\cline { 2 - 5 } 0,0 & $0,072 \mathrm{a}$ & $0,061 \mathrm{a}$ & $0,094 \mathrm{a}$ & $0,070 \mathrm{a}$ \\
0,1 & $0,068 \mathrm{a}$ & $0,058 \mathrm{a}$ & $0,114 \mathrm{ab}$ & $0,108 \mathrm{ab}$ \\
0,5 & $0,529 \mathrm{~b}$ & $0,159 \mathrm{ab}$ & $0,120 \mathrm{ab}$ & $0,145 \mathrm{~b}$ \\
1,0 & $0,622 \mathrm{~b}$ & $0,216 \mathrm{~b}$ & $0,162 \mathrm{~b}$ & $0,207 \mathrm{c}$ \\
2,0 & $0,605 \mathrm{bc}$ & $0,248 \mathrm{~b}$ & $0,132 \mathrm{ab}$ & $0,158 \mathrm{bc}$ \\
\hline Tukey (5\%) & 0,11 & 0,15 & 0,05 & 0,05 \\
F & 121,50 & 6,15 & 3,55 & 18,80 \\
C.V. & 13,61 & 47,37 & 21,39 & 17,41
\end{tabular}

a/ Mëdias de 4 repetições. 
res bem prôximos entre si, sem diferenças significativas. As sim, os dados da Tabela 3 mostram claramente que o máximo valor per missîvel de $\mathrm{S}$ na solução nutritiva com deficiência deste ele mento, seria a concentração de 0,l milimoles de s/litro, cujo txatamento, apresentou sintomas bem leves de deficiência de $\mathrm{S}$ aos 43 dìas após a germinação.

Todavia, o tratamento sem adição de $S$, apresen tou plantas com teores de enxofre bem próximos aos do tratamen to com adição de $0,1 \mathrm{milimol}$ de $\mathrm{s} / \mathrm{litro}$ de solução. Além do mais, neste tratamento sem adição de enxofre, os sintomas ví suais de deficiência de $\mathrm{S}$ somente apareceram aos 30 dias apös a germinação. Semelhante fato pode ser justificado partindo-se do princípio de que a permanência de uma semana em solução nu彑 tritiva completa para o crescimento inicial, permitiu a estas plantas a absorção de $S$ em quantiảảes suficientes para a manu tenção do seu metabolismo básico, alēm do enxofre existente co mo reserva na semente, que se apresenta em torno de 0,1\% como S-total na matéria seca, segundo dados da Tabela 7, obtidos no ensaio definitivo.

Com base nesses resultados, estabeleceu-se como critêrio para o desenvolvimento do ensaio definitivo, a elimi nação da fase de permanência das plântulas em solução nutritî va completa para o crescimento inicial por uma semana, efetuan do-se o transplante das mudas diretamente para a solução nutri tiva de trabalio.

Quanto à concentração do s para a solução nutriti 
va deficiente, optou-se por um valor intermediário entre 0,0 e 0,1 , como sendo 0,5 milimoles de $s$ por litro de solução nutrí tiva.

Para a solução nutritiva completa seria suficien te, conforme observa-se na Tabela 3 , a adição de 1,0 milimol

de $S$, mas como se pretende comparar a translocação do $S$ em con dições de solução nutritiva deficiente e completa, optou-se pe la adição de 2,0 milimoles de S/litro de solução, visando o fornecimento de $S$ em proporções de alta disponibilidade ao ni vel radicular.

\subsection{Ensaio Definitivo}

4.2.1. Efeitos observados em função da deficiência de enxofre

As plantas que se desenvolveram em solução nutri. tiva com deficiência em $S$, se mostraram diferenciadas em rela ção ãs demais, apresentando menor produção de matéria seca e grãos, conforme Tabelas 4 e 5 e 12 a 18 e Figura 3 . Ainda, es tas plantas apresentaram sintomas visuais de deficiência de $S$, logo no início da formação de vagens, aproximadamente aos 60 dias.

As anālises químicas mostraram tambēm teores in feriores de s-total em plantas deficientes, que inclusive, no final do ciclo, apresentaram teores de $\mathrm{S}$-total mais elevado em 
Tabela 4 - Médias da produção de matéria seca do feijoeiro cul tivado em soluções nutritivas completa e com defi ciência de $S$, em função dos estādios de desenvolvị mento e do crescimento apresentado entre cada perío do.

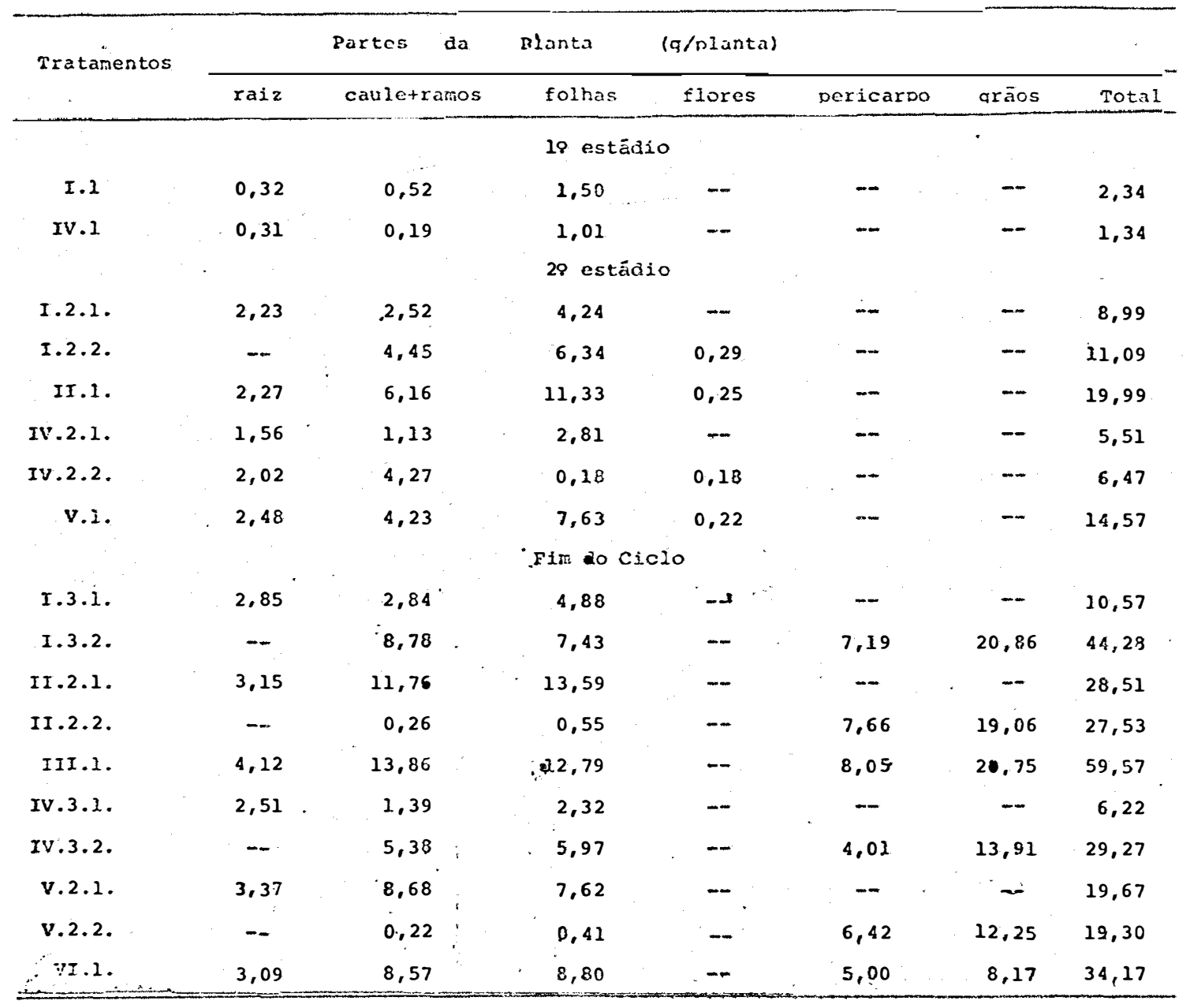




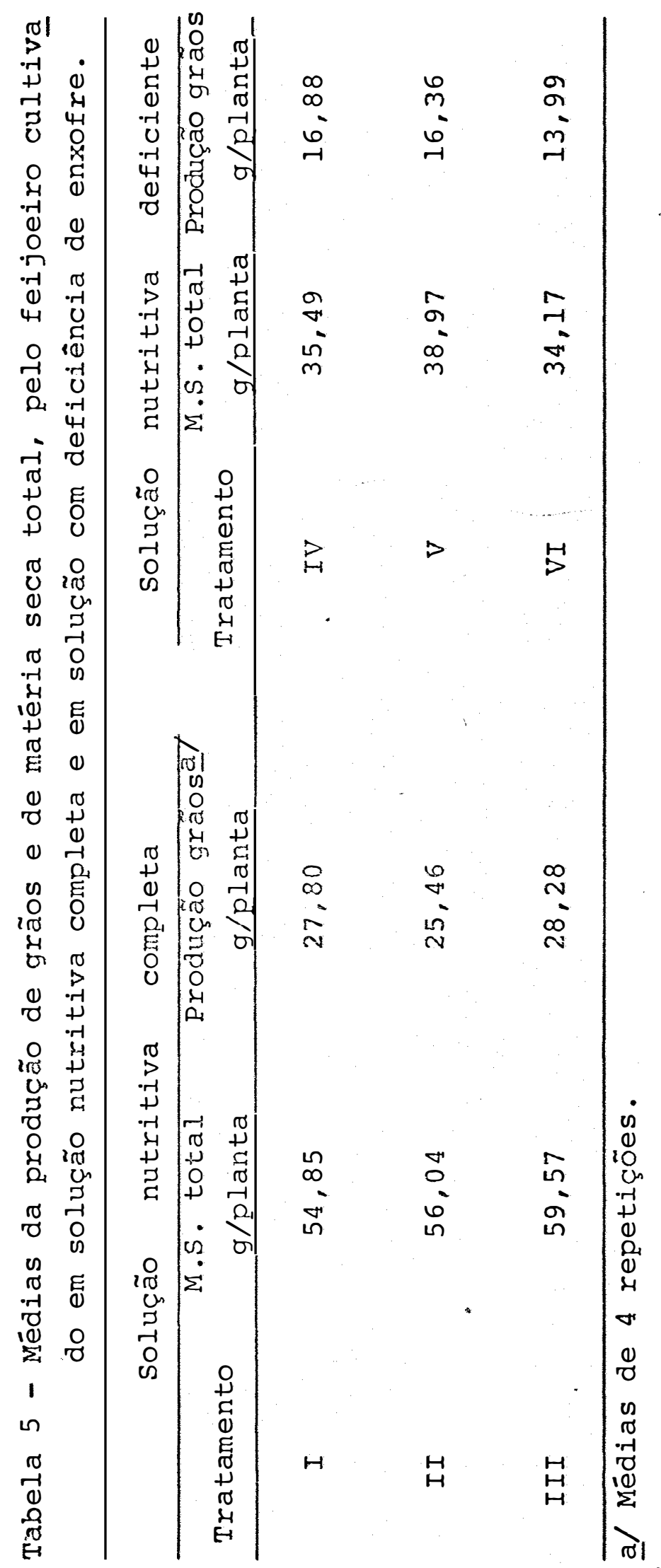




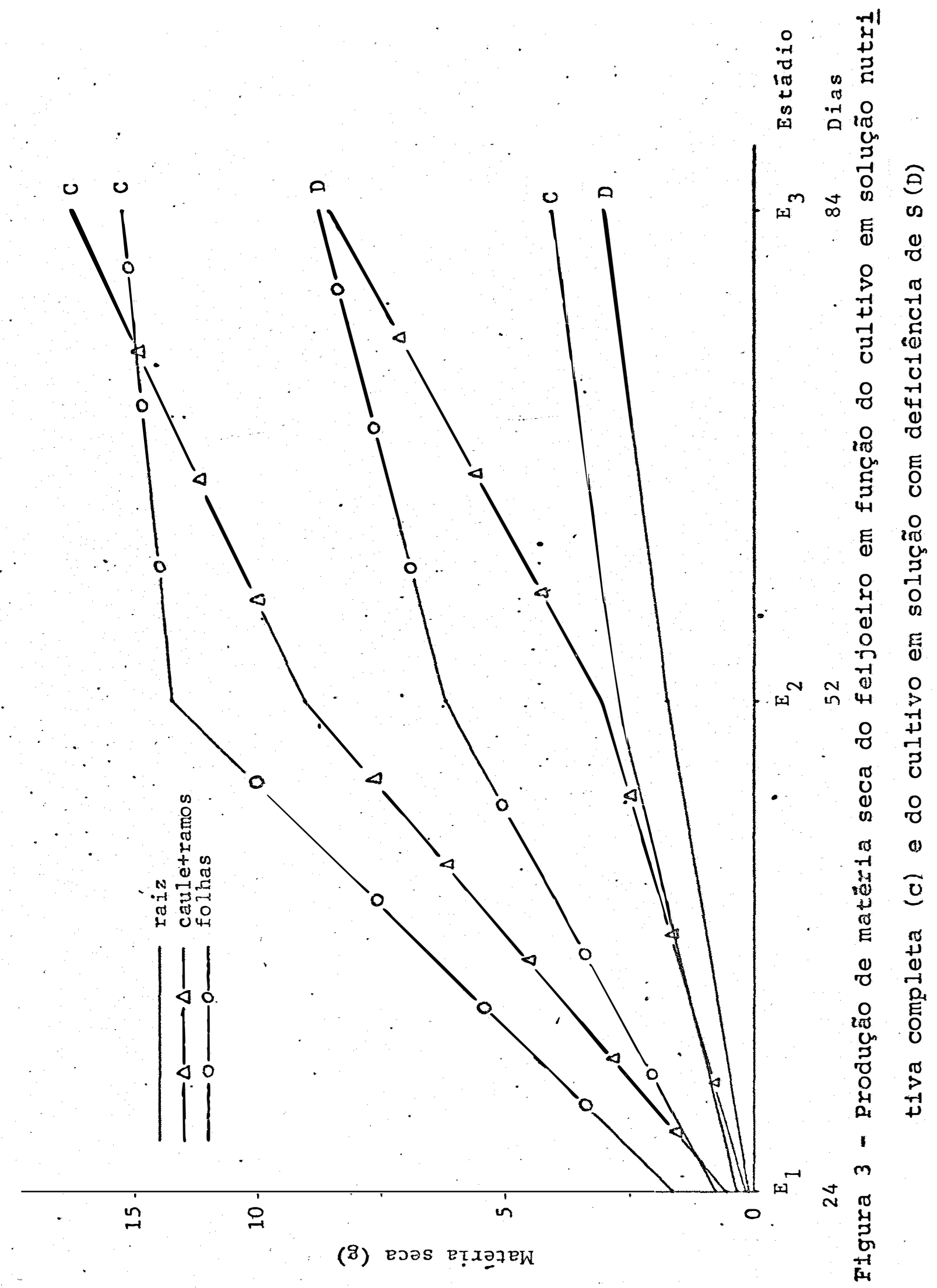


folhas do que em raízes, sendo que nas plantas cultivadas em solução nutritiva completa, este teor foi sempre maior nas raí zes, indicando que estas plantas se desenvolveram durante todo - ciclo em condições altamente suficientes em $\mathrm{S}$, segundo Tabe la 7 e Figuras 9 e 10 .

4.2.2. Redistribuição do $S$ dentro da planta

As plantas cultivadas, tanto em solução nutriti va completa como em solução com deficiência em $\mathrm{S}$, apresentaram redistribuição do enxofre, evidenciado pela detecção do ${ }^{35} \mathrm{~s}$ em partes mais jovens, representando uma fração do que. fora acumu lado nas plantas até o 10 ou 20 estäaio de desenvolvimento. Es te ${ }^{35} \mathrm{~s}$ detectado nas partes mais jovens, conforme se apresenta na Tabela 6 e Figuras 4 a 7, sô pode ser proveniente dos ōr gãos mais adultos que haviam se desenvolvido durante a fase de absorção do ${ }^{35} \mathrm{~S}$ da solução nutritiva.

Esta redistxibuição, considerando-se em percenta gem do S previamente absorvido foi maior no caso de plantas de ficientes, entretanto, quando se analisa a quantidade total de S redistribuido, observa-se que o tratamento completo exibe plantas com teor de $\mathrm{S}$ bastante elevado em relação ao tratamen to S-deficiente (Tabela 7 e Figuras 9 e 10), o que indica ser maior a quantidade de $S$ redistribuido no interior das primei ras plantas, onde o teor foliar passa de 0,6 à $0,1 \%$, entre 0 19 e 2o estádio e de 0,2 à $0,1 \%$ entre o 20 e 3o estádio (Figu 
Tabela 6 - Médias da atividade devido ao ${ }^{35}$ S-total absorvido pelo feijoeiro cultivado em soluções nutritivas completa e com deficiência de $S$, em função dos es tádios de desenvolvimento e do crescimento apresen tado entre cada período.

\begin{tabular}{|c|c|c|c|c|c|c|c|c|}
\hline \multirow{2}{*}{ Tratumentos } & \multicolumn{2}{|r|}{ Partes da } & \multicolumn{6}{|c|}{$\left({ }^{*} s-t o t a l c p s\right)$} \\
\hline & $\operatorname{ras}$ & caulctramos & folhas & flores & & pericarpo & arãos & Total \\
\hline & & $\ldots$ & 19 está & & & & & \\
\hline 1.1 & 3412 & 4162 & 12520 & -- & & -- & - & 20095 \\
\hline IV.I & 10772 & 11747 & 44893 & - & & $\cdots$ & - & 67412 \\
\hline & & ? & 28 está & & & & . & \\
\hline 1.2.1. & 3251 & $\cdot 3557$ & 5624 & -- & & -- & - & 12433 \\
\hline I.2.2. & - & 1933 & 3606 & 167 & & -- & - & 5706 \\
\hline II.I. & 22471 & 32005 & 58562 & 564 & & - & - & 113677 \\
\hline IV.2.1. & 8467 & 6200 & 25021 & - & & - & - . & 39688 \\
\hline IV.2.2. & -- & 4544 & 16089 & 446 & & -- & - & 21079 \\
\hline v.1. & 38653 & 44269 & 193685 & 5496 & 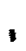 & - & -- & 282103 \\
\hline & & - & Fim do & & & & & \\
\hline I.3.1. & 2769 & 2955 & 2641 & - & & - & - & 8365 \\
\hline 1.3 .2$. & -- & 1866 & 2588 & - & & 1587 & 5104 & 11245 \\
\hline$I I .2 .1$. & 18744 & 23148 & 18276 & - & & - & - & 60168 \\
\hline II.2.2. & - & 242 & 405 & - & & 7789 & 39740 & 48176 \\
\hline III.I. & 52746 & 38791 & 21823 & - & & 29687 & 30399 & 213445 \\
\hline IV.3.1. & 4012 & 2421 & $120 \geq 8$ & - & & -- & - & 18461 \\
\hline IV.3.2. & -- & 2126 & 4950 & $-r$ & & 1277 & 19864 & 28217 \\
\hline v.2.1 & 26257 & 286.75 & 62286 & $n$ & & 28081 & $\rightarrow$ & 126118 \\
\hline v.2.2. & -- & 331 & 1130 & - & & 18081 & 90759 & 110301 \\
\hline VI.I. & 5771.6 & 96.325 & 299185 & re & & 45431 & 276272 & 574929 \\
\hline
\end{tabular}




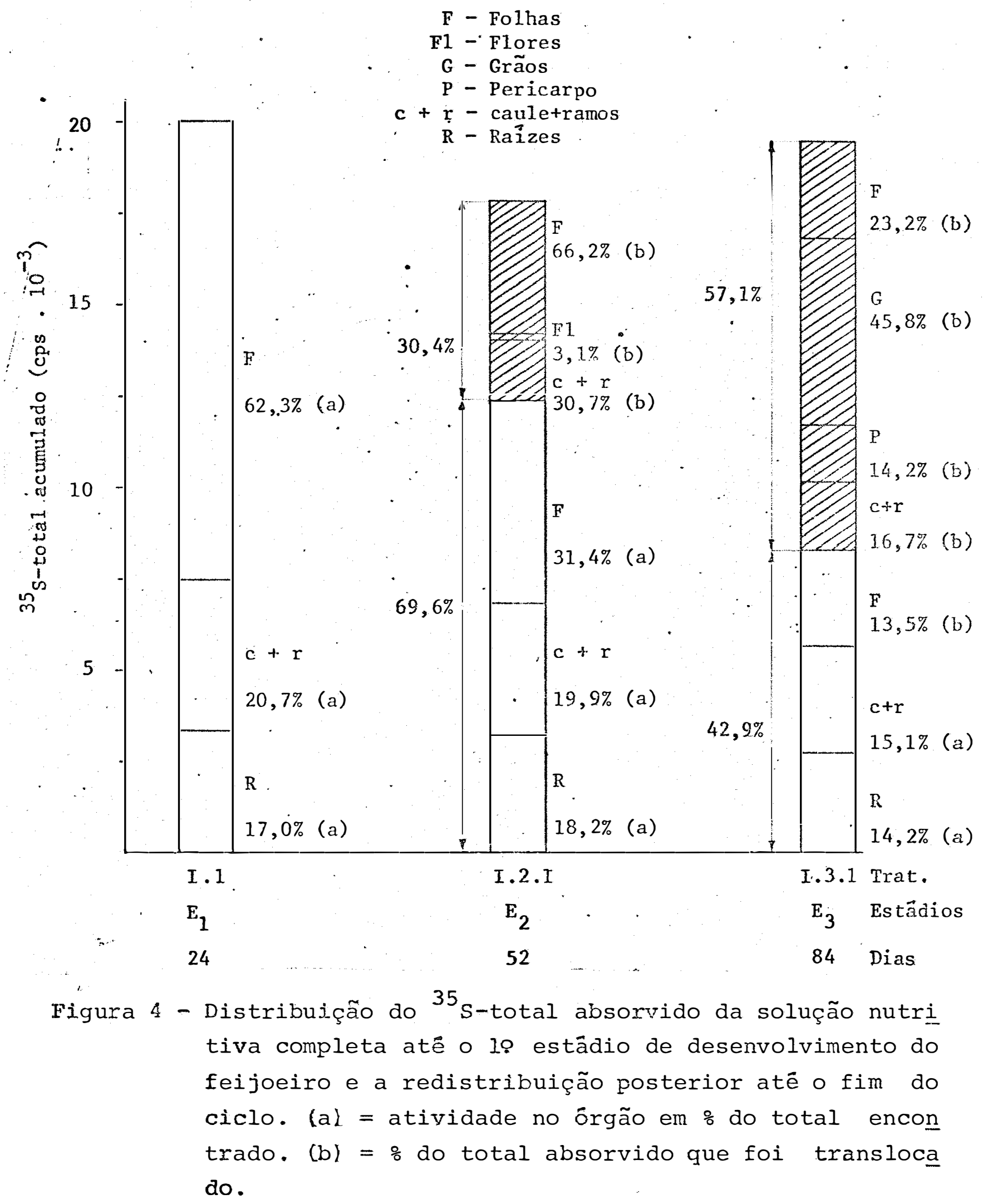




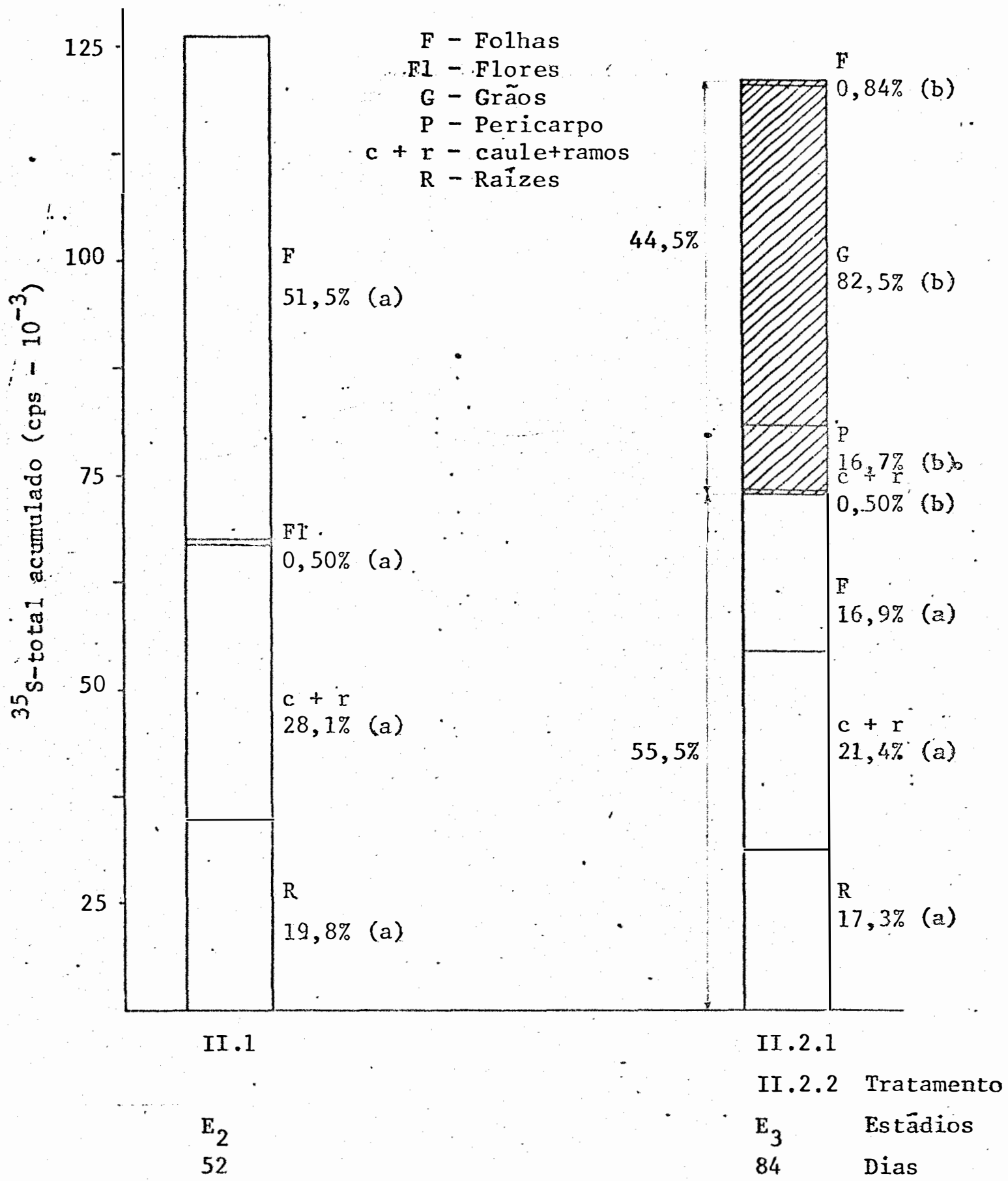

Fìgura 5 - Distribuição do ${ }^{35}$ S-total absorvido da solução nu tritiva completa atê o $2 \%$ estádio de desenvolvimen to do feijoeiro e a redistribuição posterior atê o fim do ciclo. (a) = atividade no örgão, em 8 do to tal encontrado. ( $b l=8$ do total absorvido que foi translocado. 


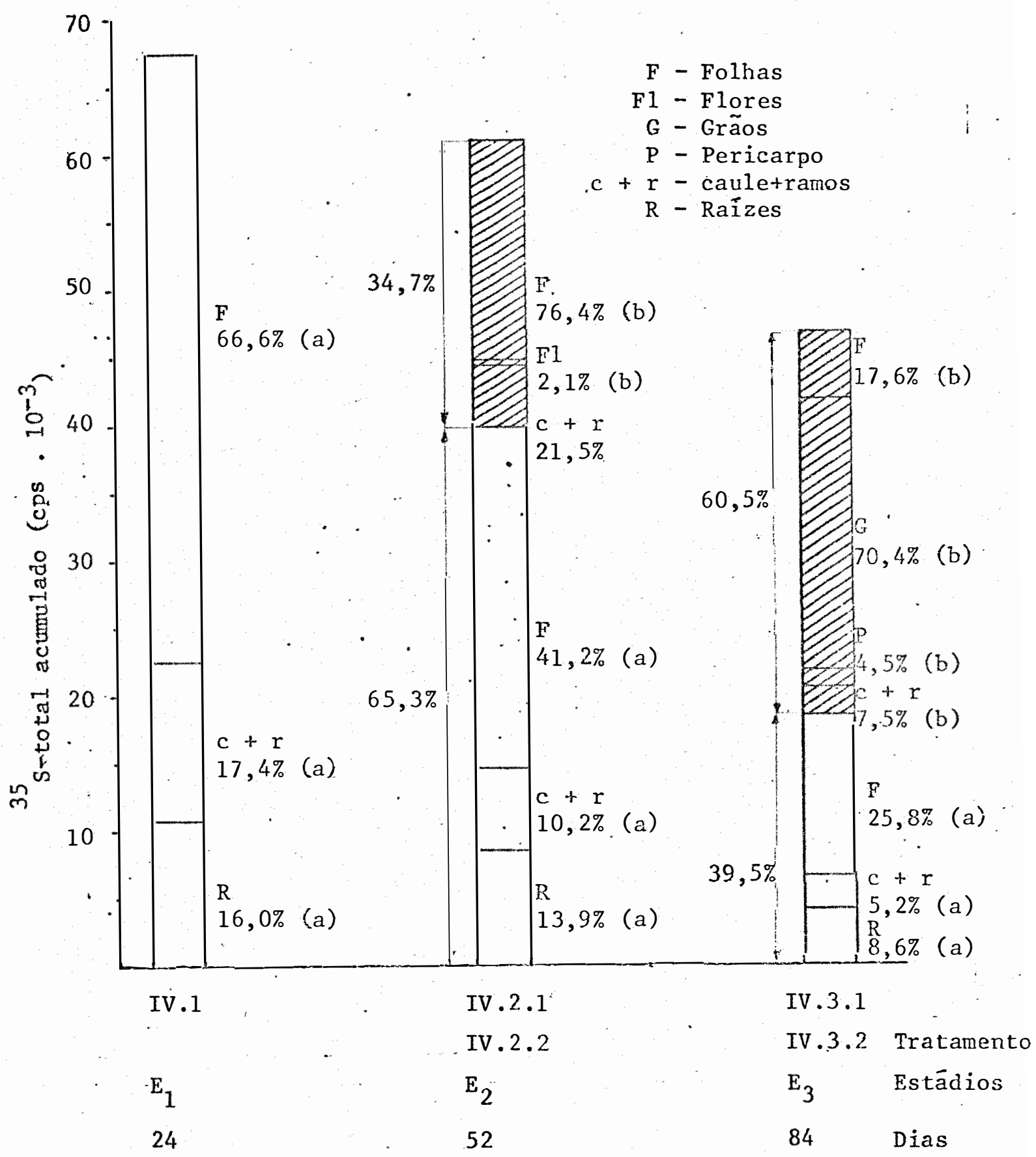

Figura 6 - Distribuição do ${ }^{35}$ S-total que foi absorvido da so lução nutritiva com deficiência em $S$ até o 10 estạ dio de desenvolvimento do feijoeiro e a redistri buição posterior atê 0 fim do ciclo. (a) = ativida de no örgão, em : do total encontrado. (b) $=\frac{\circ}{d o}$ total que foi translocado. 


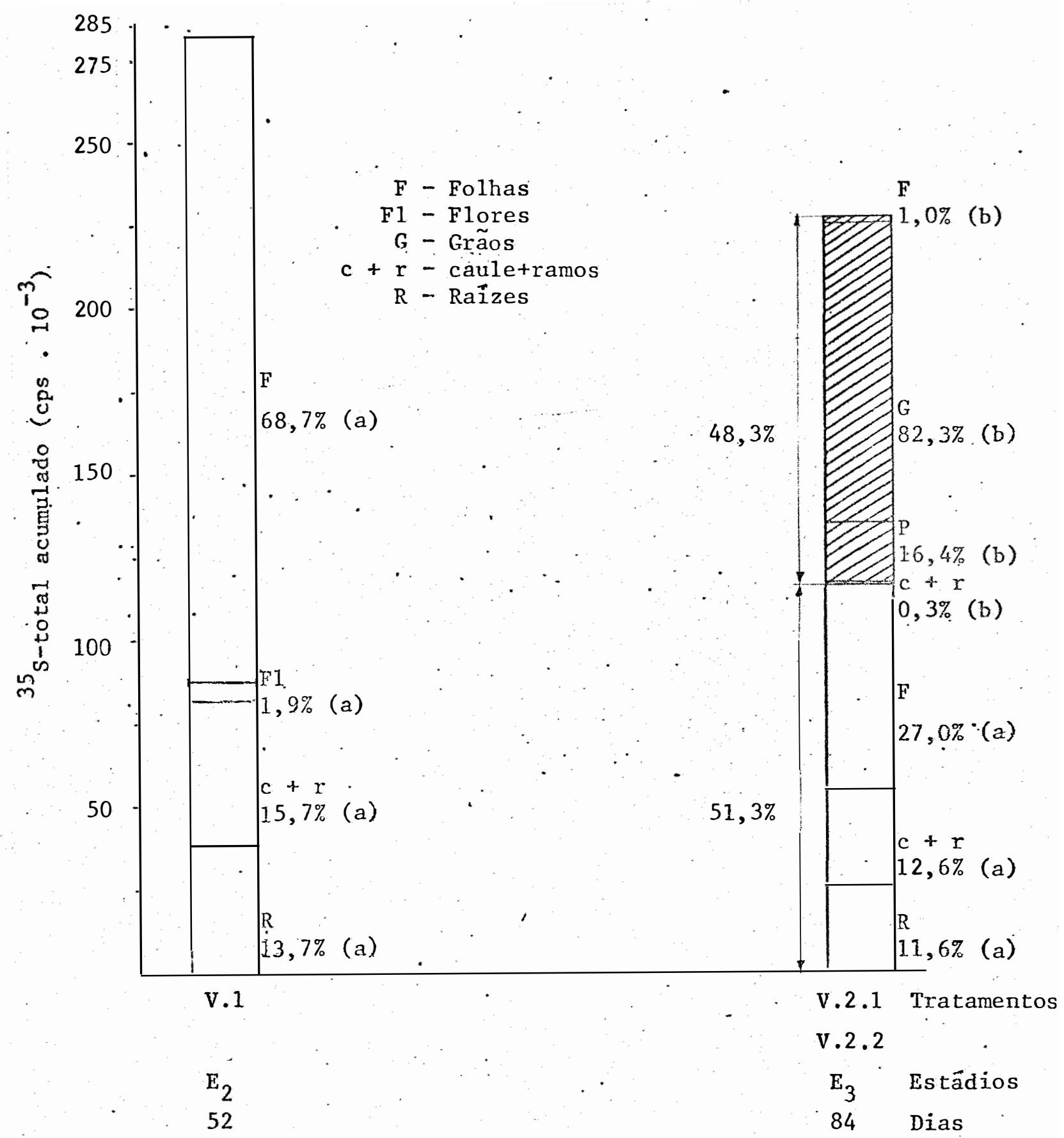

Figura 7 - Distribuição do ${ }^{35}$ s-total que foi absorvido da so Iução nutritiva com deficiência em $S$ atẻ $\circ 2 \%$ es tảdio de desenvolvimento do feijoeiro e a redistri buição postexior até o fim do ciclo. (a) = ativida de no örgão, em $\frac{\circ}{d}$ do total encontrado. $(\mathrm{b})=\frac{\circ}{\mathrm{d}}$ do total translocado. 


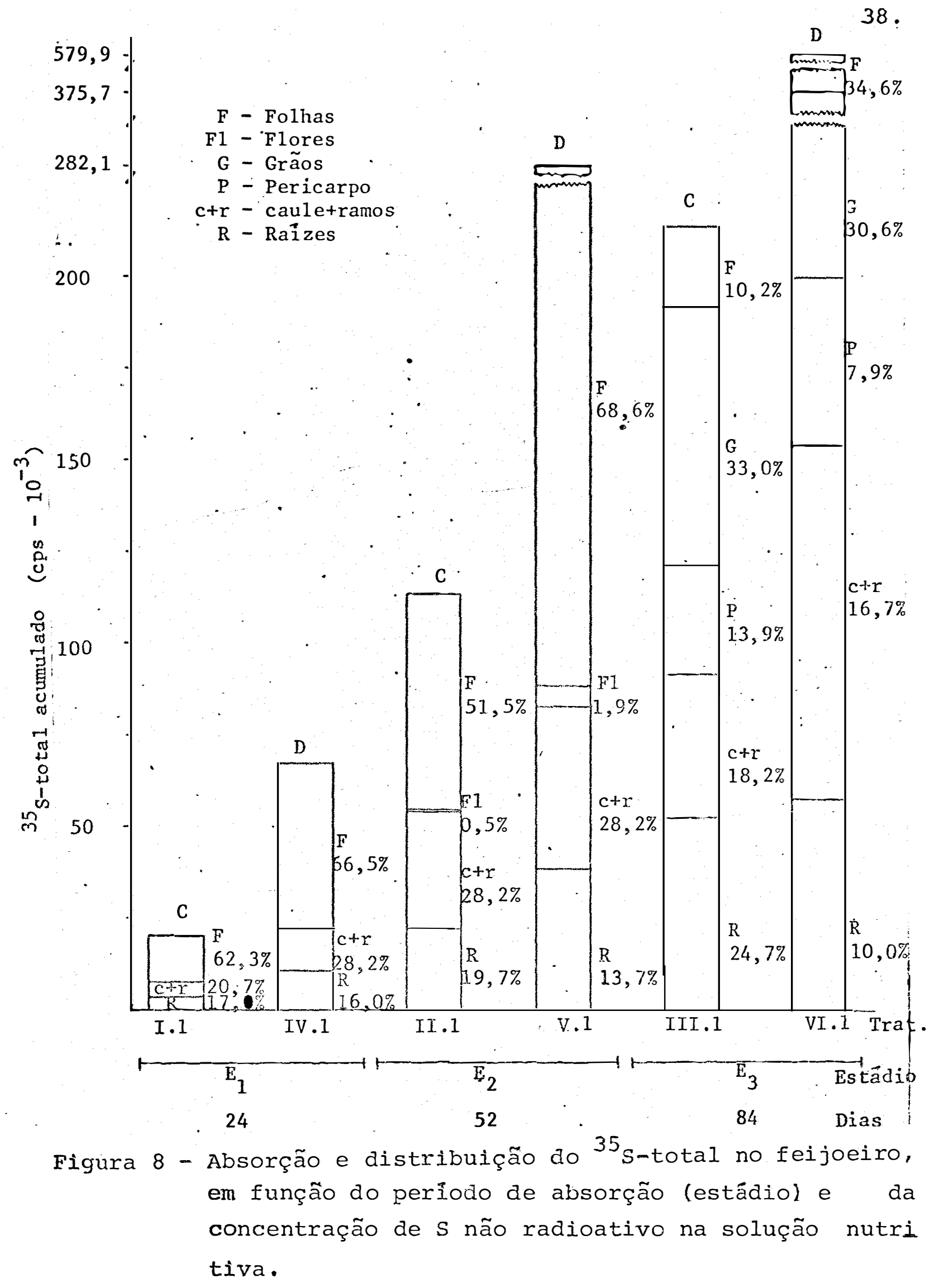


Tabela 7 - Médias do teor de s-total no feijoeiro cultivado em soluções nutritivas completa e com deficiência de S, em função dos estádios de desenvolvimento e do crescimento apresentado entre cada período.

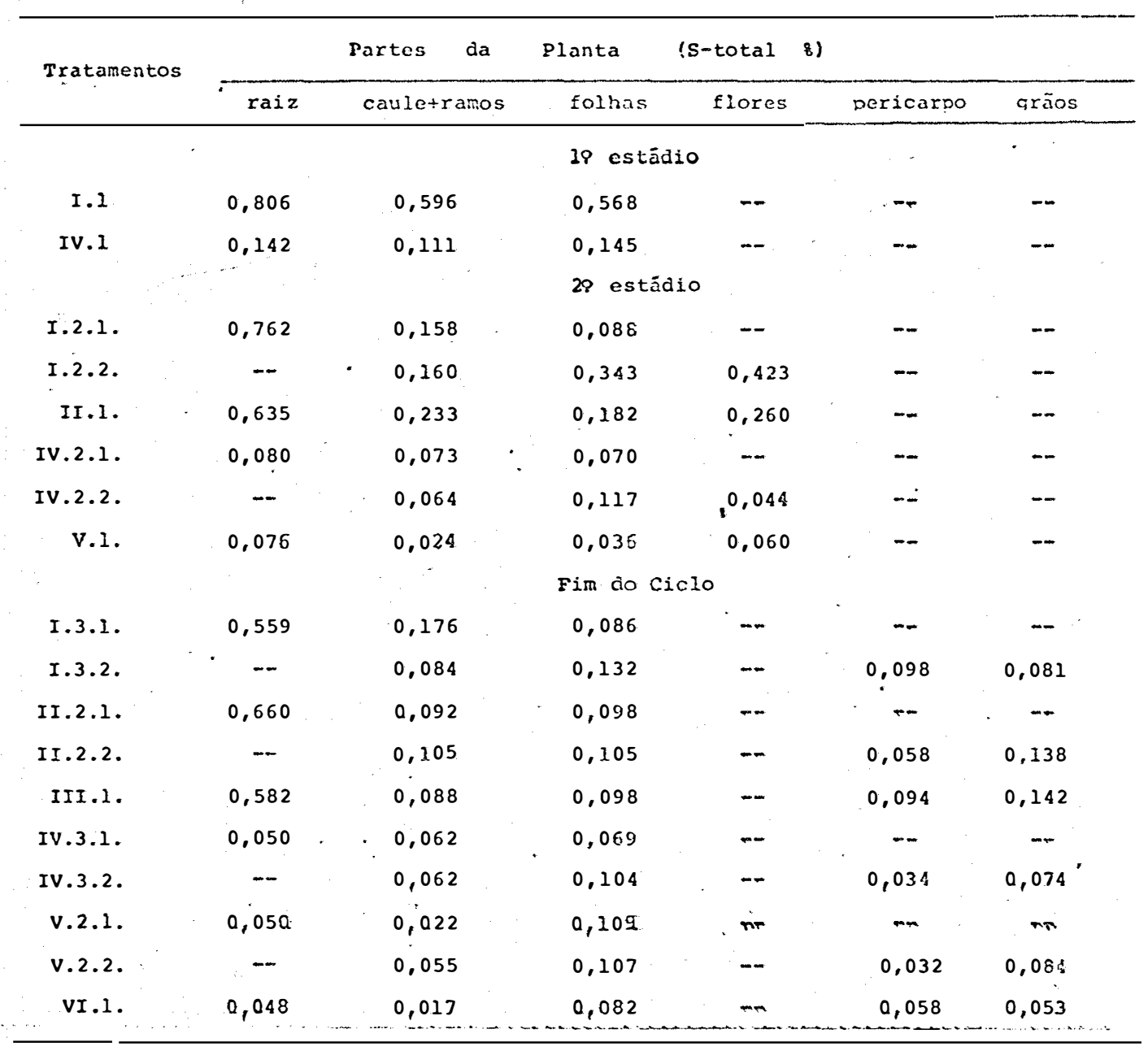




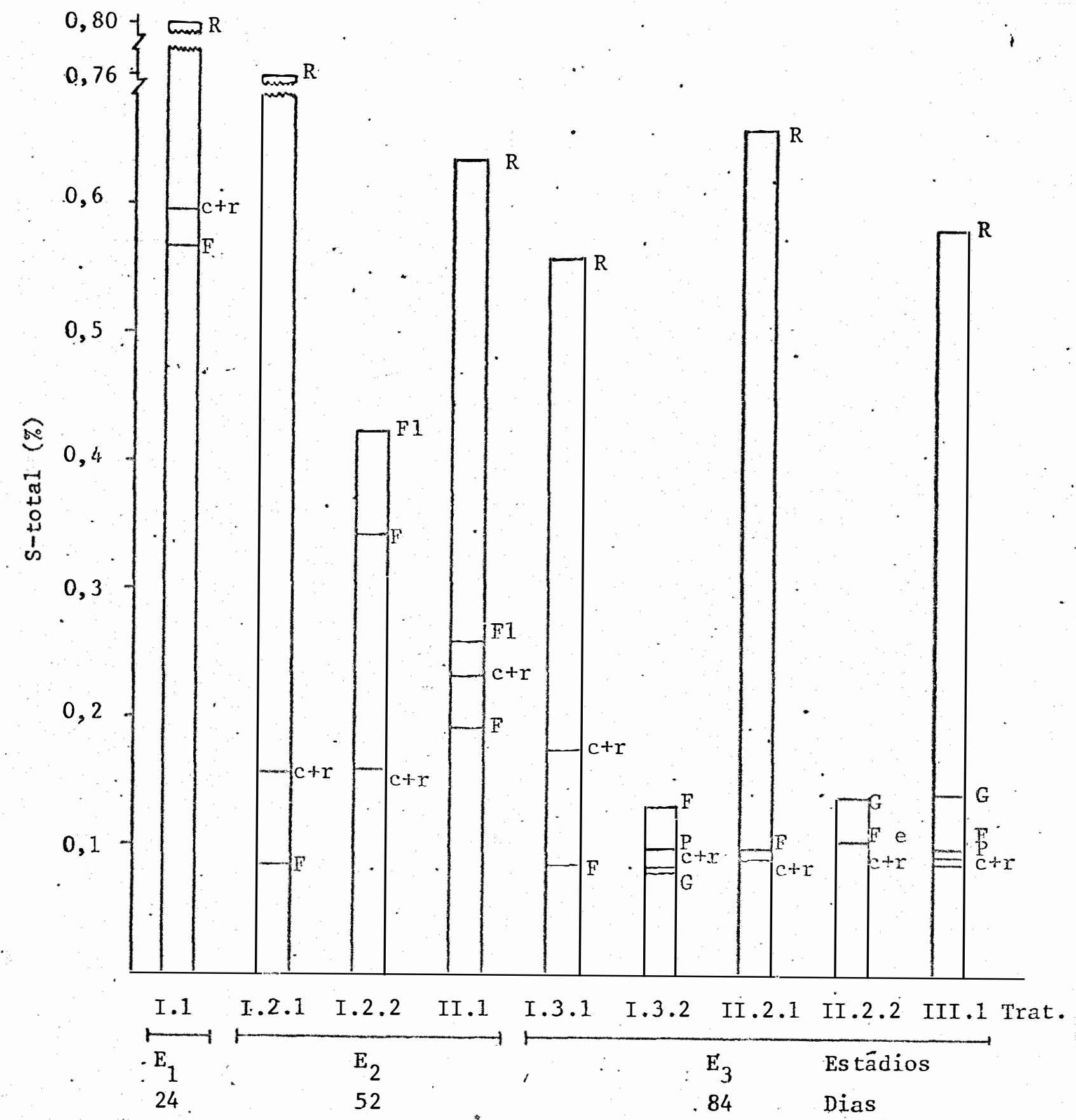

Figura 9 - Teor de s-total nos diferentes órgãos do feijoeiro cultivado em solução nutritiva completa, em função dos estádios de desenvolvimento e do crescimento ocorrido após o 19 e 2 estádio, atẻ o fim do ci clo. 
41 .

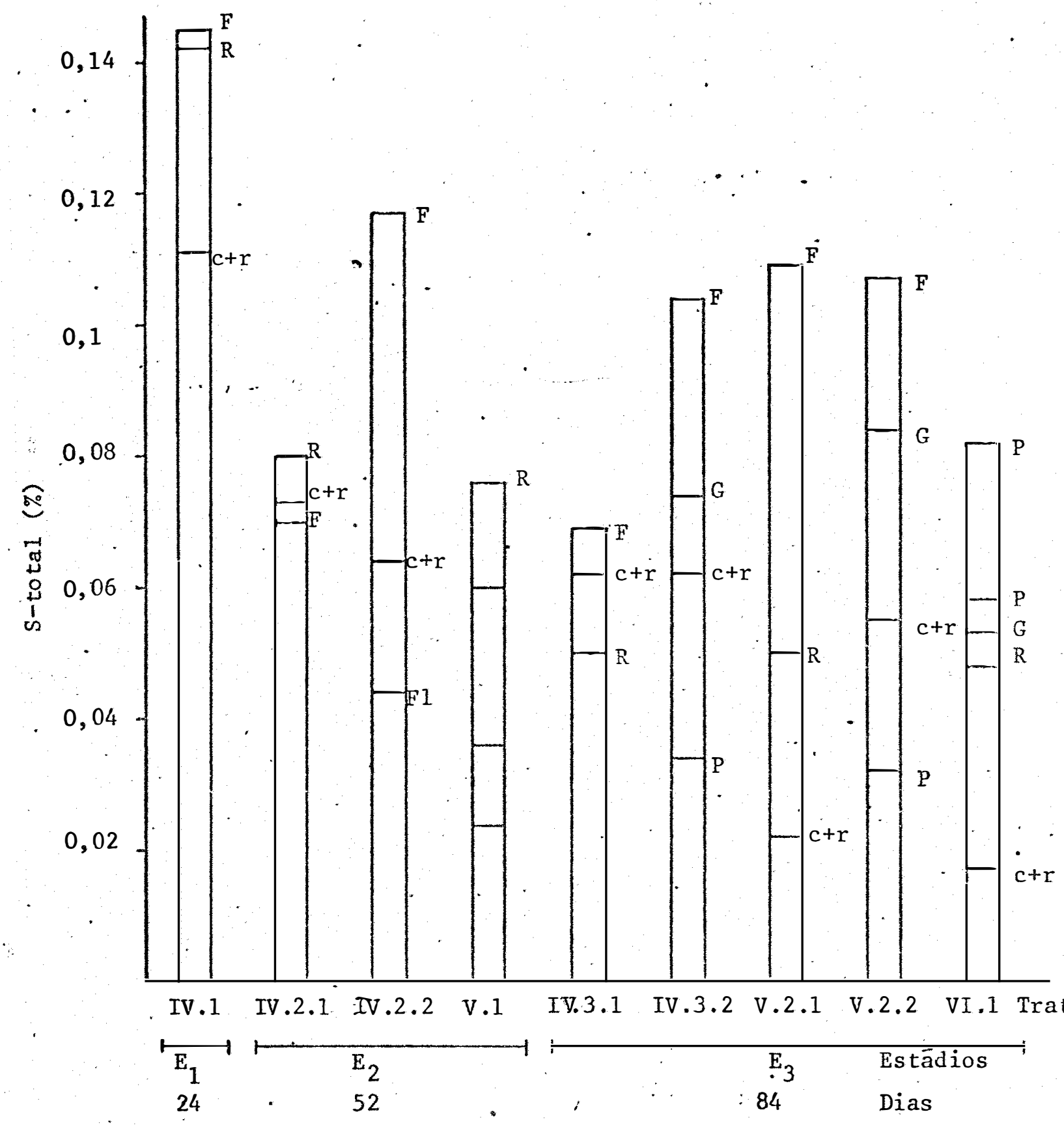

Figura 10 - Teor de s-total nos diferentes örgãos do feijoei ro cultivado em solução nutritiva com deficiência de $S$, em função dos estâdios de desenvolvịnento e do crescimento ocorrido após o $1 \%$ e $2 \%$ estảdio, até o fim do cíclo. 
ra 9l e no tratamento S-deficiente estes valores são aproxima damente 0,14 a $0,07 \%$ e 0,04 a $0,1 \%$ respectivamente (Figura 10). Considerando-se os diferentes estádios de desen volvimento, observa-se que os tratamentos completo e deficien te em S exibiram plantas cuja redistribuição ocorreu até $02 \%$ estádio, de folhas adultas para folhas jovens principalmente, e do 2 estádio até o fim do ciclo a redistribuição ocorreu qua se que totalmente de folhas adultas para os grãos e pericarpo, sendo desprezîvel a fração que se translocou para folhas novas e para caule e ramos (Figuras 4 e 6 ). Os demais órgãos como raiz e caule + ramos, em termos de atividade devido ao ${ }^{35} \mathrm{~S}$, so freram pequenas alterações, exceto para o tratamento deficien te em $S$, no qual houve uma considerável diminuição na ativida de, sugerindo uma possîvel contribuição destes órgãos na frạ ção de S-total redistribuido, principalmente para o tratamento

- IV, durante os 3 estädios (Figura 6$)$. Semelhante fato é bastan te coerente, uma vez que estas plantas deficientes, para suprir a semente da quantidade necessáxia de $S$, deve exaurir os de mais ôrgãos até que estes atinjam um teor minimo permissivel. Nas plantas do tratamento completo, semelhante fato não chega a ocorrer, uma vez que suas folhas puderam acumular enxofre em quantidades suficientes, apresentando portanto uma maior fra ção de $\mathrm{S}$ disponivel para ser redistribuido aos demais órgãos.

Nas plantas do tratamento completo, $0^{35} \mathrm{~S}$ foliar acumulado até o 10 estádio $\left(E_{1}\right)$ é quase que totalmente redis tríbuido, restando no fim do ciclo apenas $13,5 \%$ da atividade 
total encontrada (Figura 4), contra 26,0\% que restou no caso de folhas de plantas deficientes em S (Figura 6). Esta fração da atividade retida representa provavelmente a ${ }^{35} \mathrm{~S}$ partici pante na estrutura foliar, que sendo maior no caso de plantas deficientes, justifica-se a necessidade da contribuição dos dẹ mais órgãos na redistribuição do $s$, principalmente para os grãos em formação.

As plantas testemunhas que se desenvolveram duㅡ rante todo o ciclo em solução radioativa apresentaram na dis trỉbuição da atividade total, em todos os estädios, uma maior fração de ${ }^{35} \mathrm{~S}$ foliar no tratarnento deficiente (Figura 8 ) o que sugere ser esta uma forma de compensação existente nas plantas deficientes, concentrando rass folhas a maior proporção possî vel do S na forma disponîvel para a posterior redistribuiçäo.

Durante o ciclo normal do feijoeiro, observou-se em todos os tratamentos, que a maior fração do $\mathrm{S}$ redistribuica ocorreu entre os $2 \%$ e 39 estádios, que se apresentcu ao redor de 40 a $60 \%$ do total absorvido. Entre o 19 e $2 \%$ estádio este valor ficou em torno de $30 \%$ do total (Tabela 6 e Figuras 4 a 71.

Os dados obtidos referentes à redistribuição do $S$ em feijoeiro estão parcialmente de acordo com a literatura, onde NETTO et alii (1971) observaram em feijoeiro aos 40 - 50 dias apôs a semeadura, uma queda brusca no teor percentual de S foliar e GALLO e MYASAKA (1961) que evidenciaram a tendência do $S$ em migrar para partes jovens ainda em formação. Por outro 
lado estes mesmos autores e WOOD (1942) observaram uma diminui ção mais evidente neste teor foliar, quando a cultura foi con duzida em nỉveis deficientes do $S$, sendo que no presente en saio, o teor de S-foliar sofreu pequena diminuição, uma vez que, devido às condições de deficiência, o mesmo já era muito baixo. Ainda, os dados obtidos contrariam aqueles obti dos por WOOD (1942) onde o autor afirma que exceto em condi ções de deficiência o s-sulfato è relativamente imóvel nas fo lhas de diferentes culturas e o enxofre necessārio é transpor tado das raỉzes para as āreas onde for requerido.

\subsubsection{Formas de translocação}

Uma vez constatado a redistribuição do $S$, tanto para plantas do tratamento completo como para s-deficiente, os dados da Tabela 10 e das Eiguras 4 a 7, sugerem a hipótese de que o s é absorvido pelas raizes e conduzido até as folhas, on de sofre uma "transformação" para uma forma diferente daquela absorvida pelas raỉzes. Somente depois disto è que o $\mathrm{S}$ poderā então ser redistribuido para outros örgãos. Assim, estas fo lhas, funcionariam como unidade de preparo do $\mathrm{s}$ a ser redistri buido no momento exato da formação do fruto (vagem). Conforme se observa nas Figuras 5 e 7, entre 029 e 39 estádio, no qual ocorre a formação das vagens, as folhas novas formadas neste perïodo contam com uma parcela insignificante do ${ }^{35} \mathrm{~s}$ redistri buido, mas cujo teor de s-foliar è praticamente igual às fo 
lhas mais velhas (tratamento II.2.1. e II.2.2., Figura 9) e do mesmo modo para o tratamento V.2.1. e V.2.2., Figura 10). Is to indica, que estas folhas novas, receberam o s quase que to talmente da solução nutritiva, porēm, quanto aos grãos, nota-se que os mesmos acumularam em termos de atividade, acima de $80 \%$ do total do $s$ que foi redistribuido e que as folhas mais velhas que haviam acumulado ${ }^{35} \mathrm{~S}$ até o 2 e estádio, sofreram uma redução na atividade no 3 : estádio, de $51,5 \%$ para $16,9 \%$ para o tratamento completo (Figura 5) e de 68,7\% para 27,0\% para o tratamento deficiente em S (Figura 7). Ainda, a Tabela $7^{\circ}$ e as Figuras 9 e 10, mostram que apesar da redução ocorrida na ati vịdade foliar, o seu teor de s-total (\%) sofreu somente uma pe quena alteração, quando se compara folhas velhas e novas den tro do mesmo estádio ou entre o 29 e 39 estādio. E justamente esta redução da atividade (que representa a retirada de $\mathrm{s}$-fo iiarl, sem no entanto ser acompanhada proporcionalmente da dí minuição do teor de $S$, indicando ter havido nestas folhas uma reposição do $\mathrm{S}$ redistribujdo, vindo da raiz (solução nutriti val, que sugere a dependência deste elemento em passar primeí ro pelas folhas, ser transformado e depois sofrer redistribui ção, principałmente para os grãos em foṛmação.

\section{Caso contrárió, estas plantas, principalmente} aquelas conduzidas em solução nutritiva completa, onde o se en contrava disponível (evidenciado pelo alto teor de $\mathrm{S}$ nas raí zes, segundo Figura 9), poderia efetivamente transportar dire tamente das raỉzes o $S$ necessārio para os grãos. Além disto, 
nota-se que as raỉzes mantiveram durante todo o ciclo uma al ta concentração de $S$, mas que, praticamente contribuiram muito pouco na fração de ${ }^{35}$ S redistribuido (Figuras 4 e 5).

Embora não tenha sidö encontrado nenhuma litera tura a respeito, seja por falta de acesso às mesmas, ou por não existir simplesmente nenhum trabalho que possa. sugerir qualquer hipôtesè a respeito, é provāvel que exista alguma di ferença entre o complexo enzimático foliar ligado ao metabolis mo do $s$ e o daquele existente no sỉtio de formação do grão, o "que possibilitaria a este ültimo, somente metabolizar e incor porar uma forma de $S$ pré-elaborado nas folhas destas plantas.

Quanto à natureza deste composto, se orgânica ou ìnorgânica parece uma questão ainda sem resposta definitiva, sendo os dados da literatura escassos e bastante vagos.

Segundo THOMAS et alii (1944a), o s-orgânico fo liar foi transformado em s-inorgânico para ser translocado e voltando novamente à forma orgânica nas raízes e grãos. NIGH TINGAIE et alii (1953), observaram em cultura de tomateiro que os compostos orgânicos de $\mathrm{S}$, uma vez sintetizados podem subse quentemerte sofrer proteólise, ser translocados e reutilizados nos tecidos meristemáticos. Todavia, ERGLE (1954) não observou nenhuma evidência desta translocação e reutilização do enxofre em seus estudos com algodoeiro. Quanto à forma orgânica de $\mathrm{S}$, segundo TOLBERT e WIEBE (1955l nada pode ser evidenciado quan do se analisou a seiva dos xilemas de Hordeum vulgare (cevada), 
Spinacea oleracea (espinafre) e Cucumis sativus (pepinol.

Segundo os dados obtidos no presente ensaio, atra vês das Tabelas 8 e 9 e Figuras 11 a 14 , onde são apresenta dos os teores de $\mathrm{S}_{-\mathrm{SO}_{4}}=$ e s-orgânico em função dos estádios de desenvolvimento e do crescimento apresentado entre cada pe xỉodo, observa-se para as plantas cultivadas em solução nutri tiva completa, que os teores de $\mathrm{S}^{-\mathrm{SO}_{4}} \overline{\bar{A}}$ föliar (Figura 11 ), que se: apre sentou comoo principal órgão envolvido no processo de redistrí buição, apresenta redução na folha adulta que cedeu $\circ \mathrm{s}$ e um aumento na folha nov.a que recebeu $\mathrm{S}$, evidenciando ser $0 \mathrm{~S}_{-\mathrm{SO}_{4}}=$ uma provāvel forma de redistribuição deste elemento. Por outxo lado, os teores de S-orgânico, Figura 13, apresentam comporta mento semelhante, sugerindo que uma parte do s-orgânico foliar (fração disponĩvel) se oxida a sulfato e se redistribui para os órgãos em formação.

Quanto às plantas do tratamento S-deficiente, as variações nos teores de $\mathrm{S}^{-\mathrm{SO}_{4}}=$ e S-orgânịco, Figuras 12 e 14, respectivamente, se mostram insuficientes para quaisquer con clusẽes, apresentando uma leve tendência contrâria ao observa do no trátamento completo, ou seja, teores mais elevados de $\mathrm{S}-\mathrm{SO}_{4}=$ em folhas adultas do que em folhas novas. Provavelmente, devido ao metabolismo do enxofre ser mais intenso nestas plan tas, provocado pela deficiência do mesmo, alēm da possibilida de de que o próprio teor muito baixo de $\mathrm{S}$ tenha fugido à sensí bilidade dos métodos analíticos empregados, ficando demonstra do, não ser aconselhâvel trabalhar com plantas deficientes em 
Tabela 8 - Mëdias do teor de $\mathrm{S}_{-\mathrm{SO}_{4}}^{=}$no feijoeiro cultivado em soluções nutritivas completa e com deficiência de S, em função dos estádios de desenvolvimento e do crescimento apresentado entre cada período.

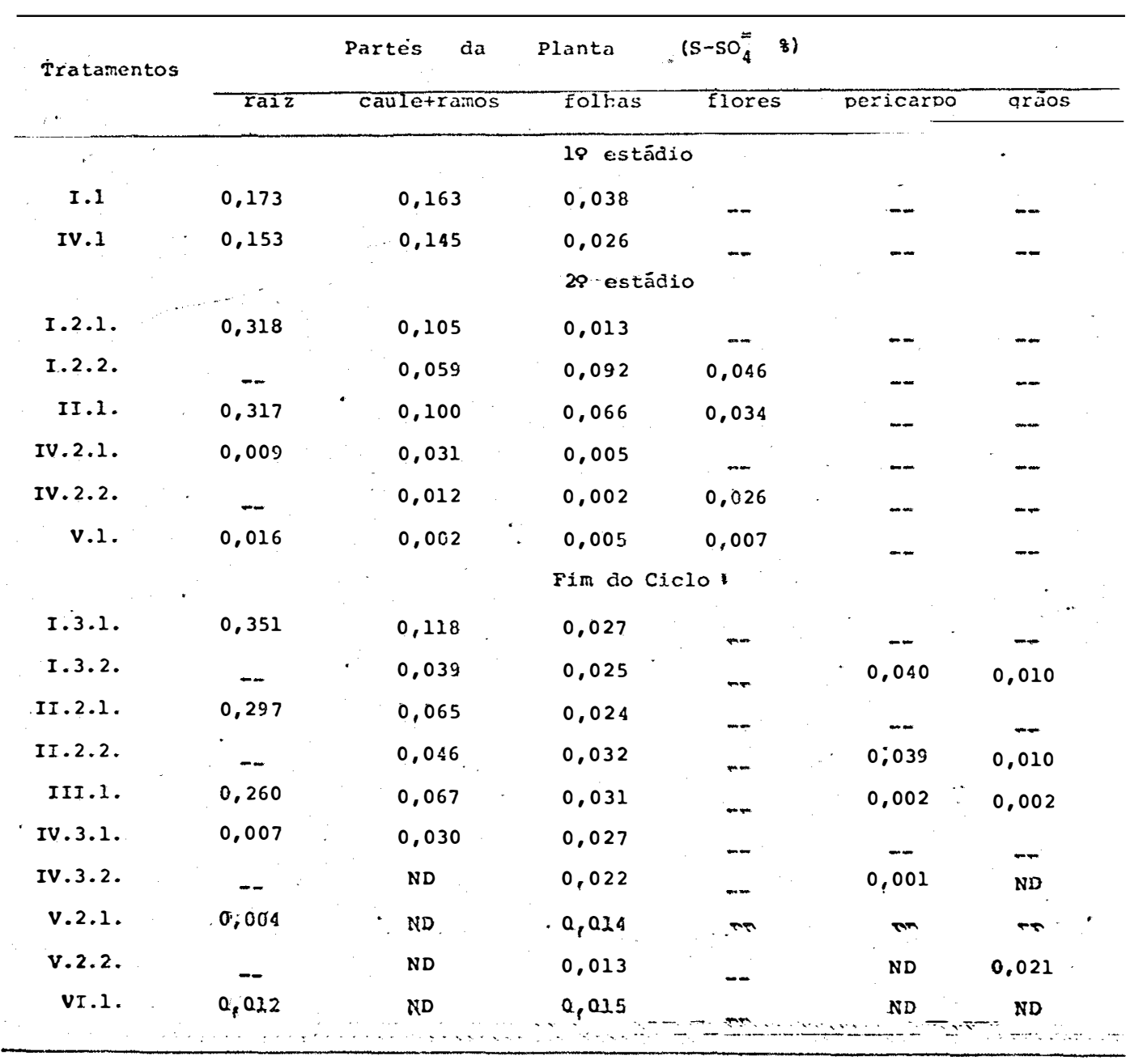




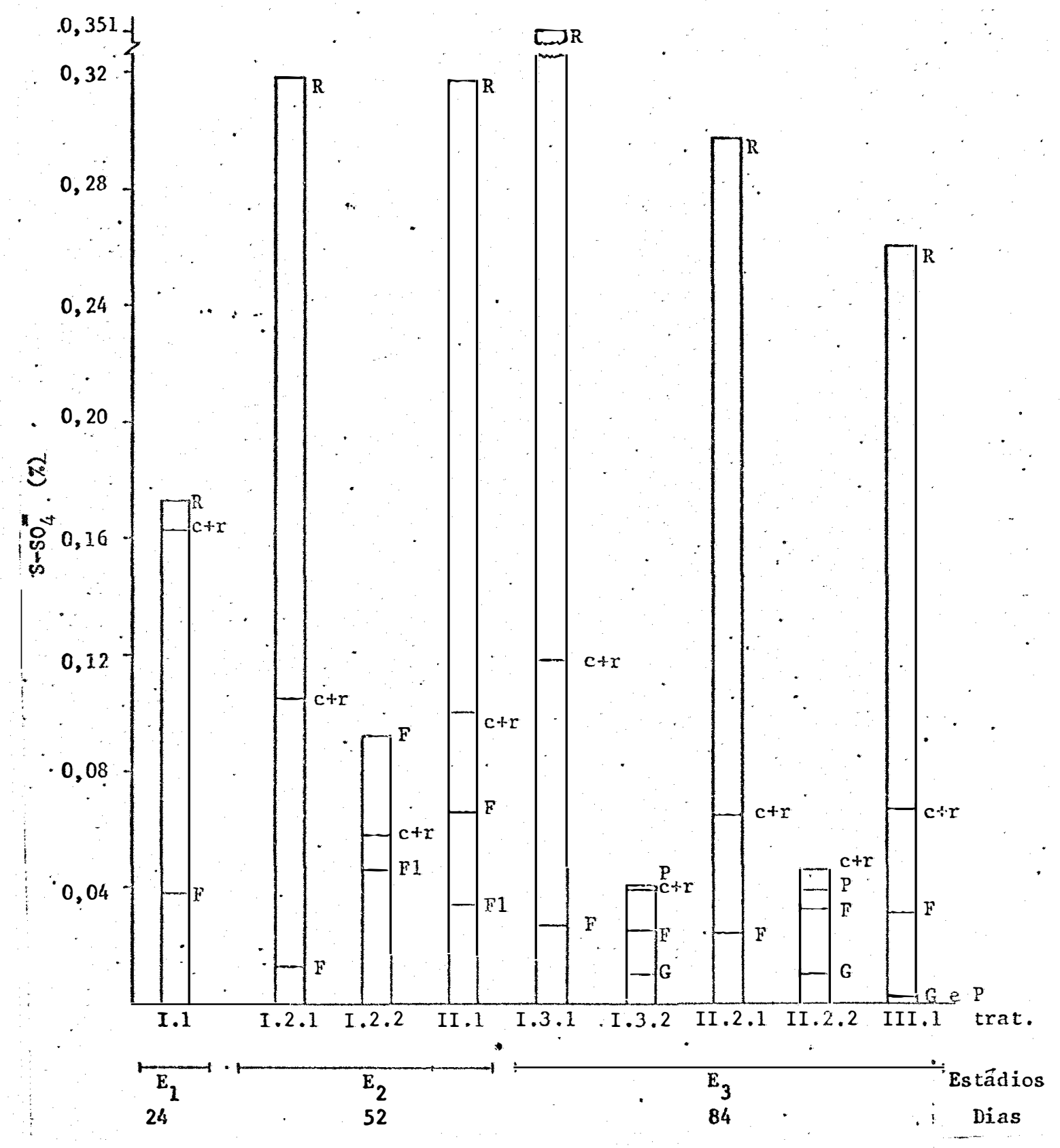

Figura 11 - Teor de $\mathrm{S}-\mathrm{SO}_{4}^{=}$nos diferentes órgãos do feijoeiro cultivado em solução nutritiva completa, em fun ção dos estâdios de desenvolvimento e do cresci mento ocorrido apôs o 19 e 2 . estádio, atẻ o fim do ciclo. 


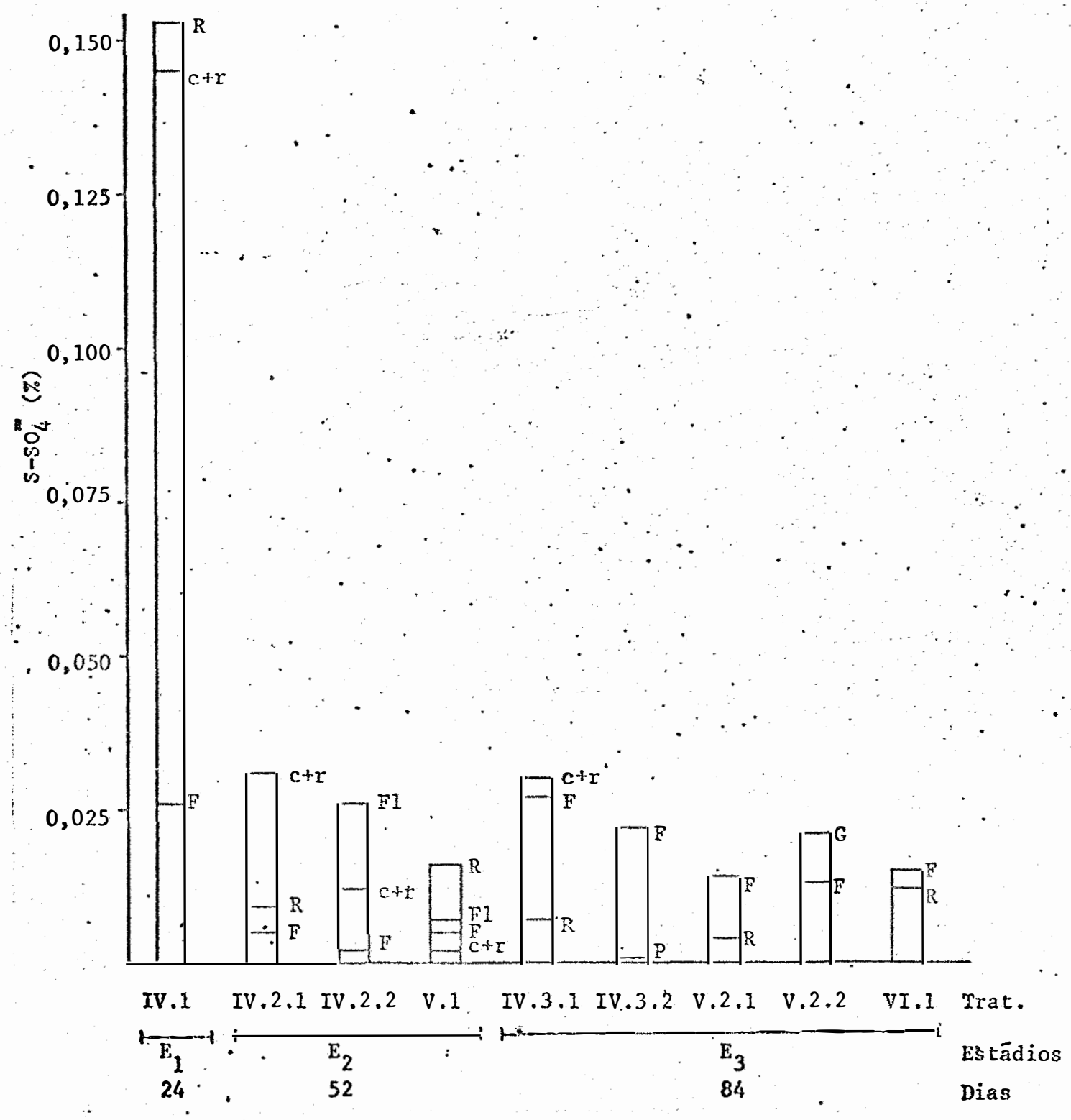

Figura 12 - Teor de $\mathrm{S}^{-\mathrm{SO}_{4}}=$ nos diferentes órgãos do feijoeiro cultivado em solução nutritiva com deficiência de $S$, em função dos estâdios de desenvolvimento e do crescimento ocorrido apôs o $1 \%$ e $2 \%$ estádio, atê o fim do ciclo. 
Tabela 9 - Médias do teor de s-orgânico no feijoeiro cultiva do em soluções nutritivas completa e com deficiên cia de $S$, em função dos estádios de desenvolvimen to e do crescimento apresentado entre cada perío do.

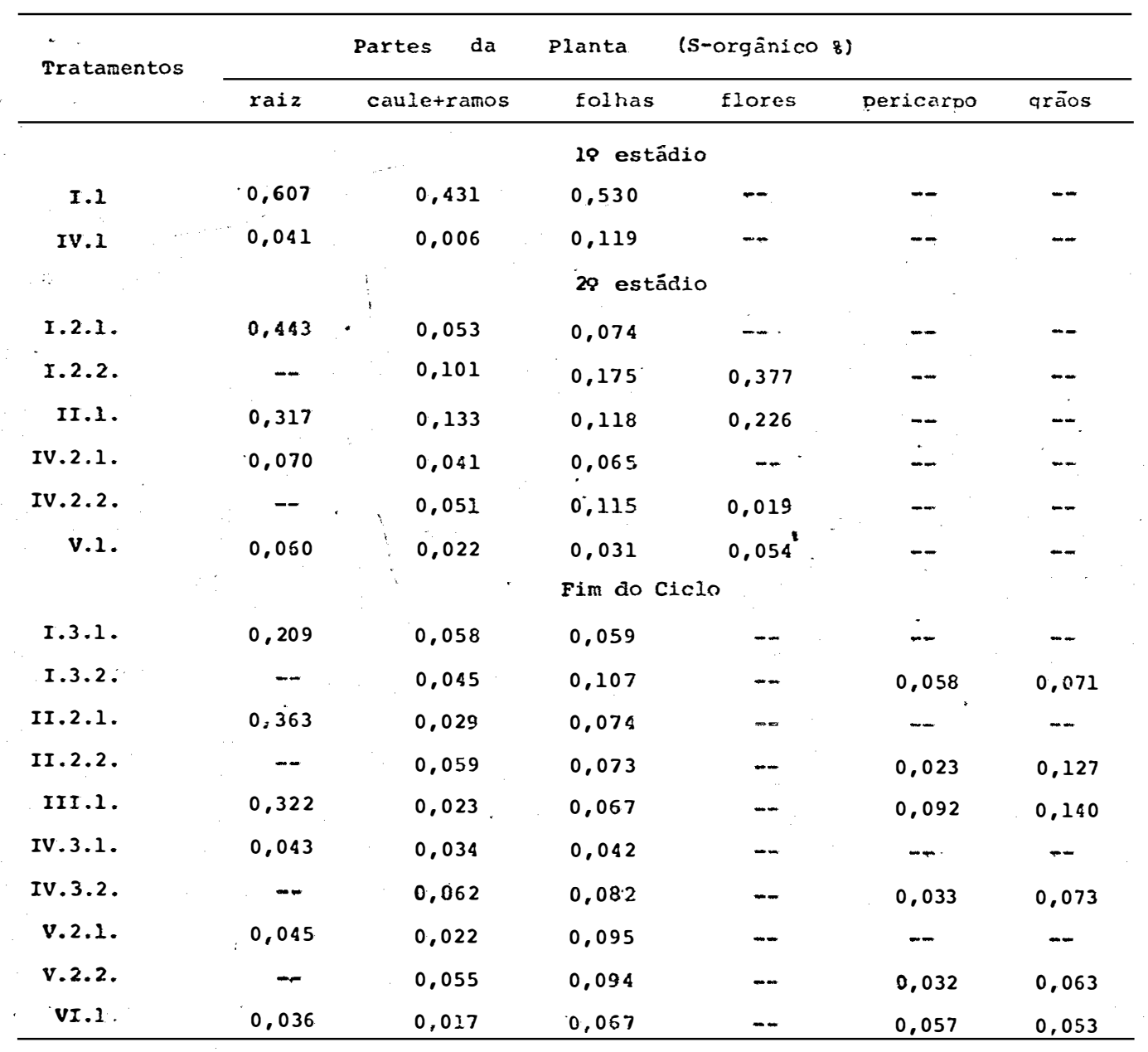


52.

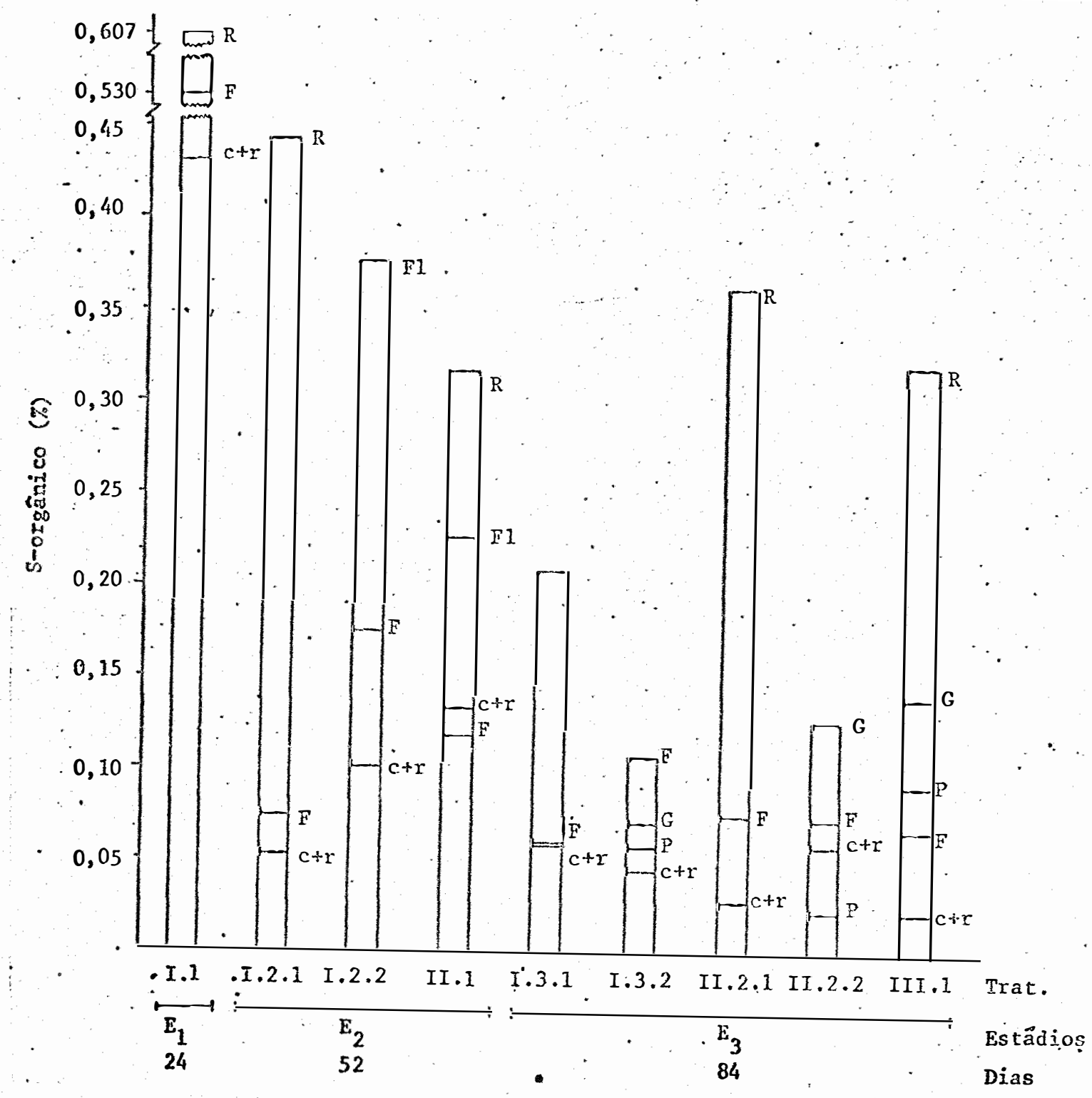

Figura 13 - Teor de s-orgânico nos diferentes órgãos do fei joeiro cultivado em solução nutritiva completa, em função dos estâdios de desenvolvimento e do cres cìmento ocorrido apôs o lo e $2 \%$ estâdio, até ó fim do ciclo. 


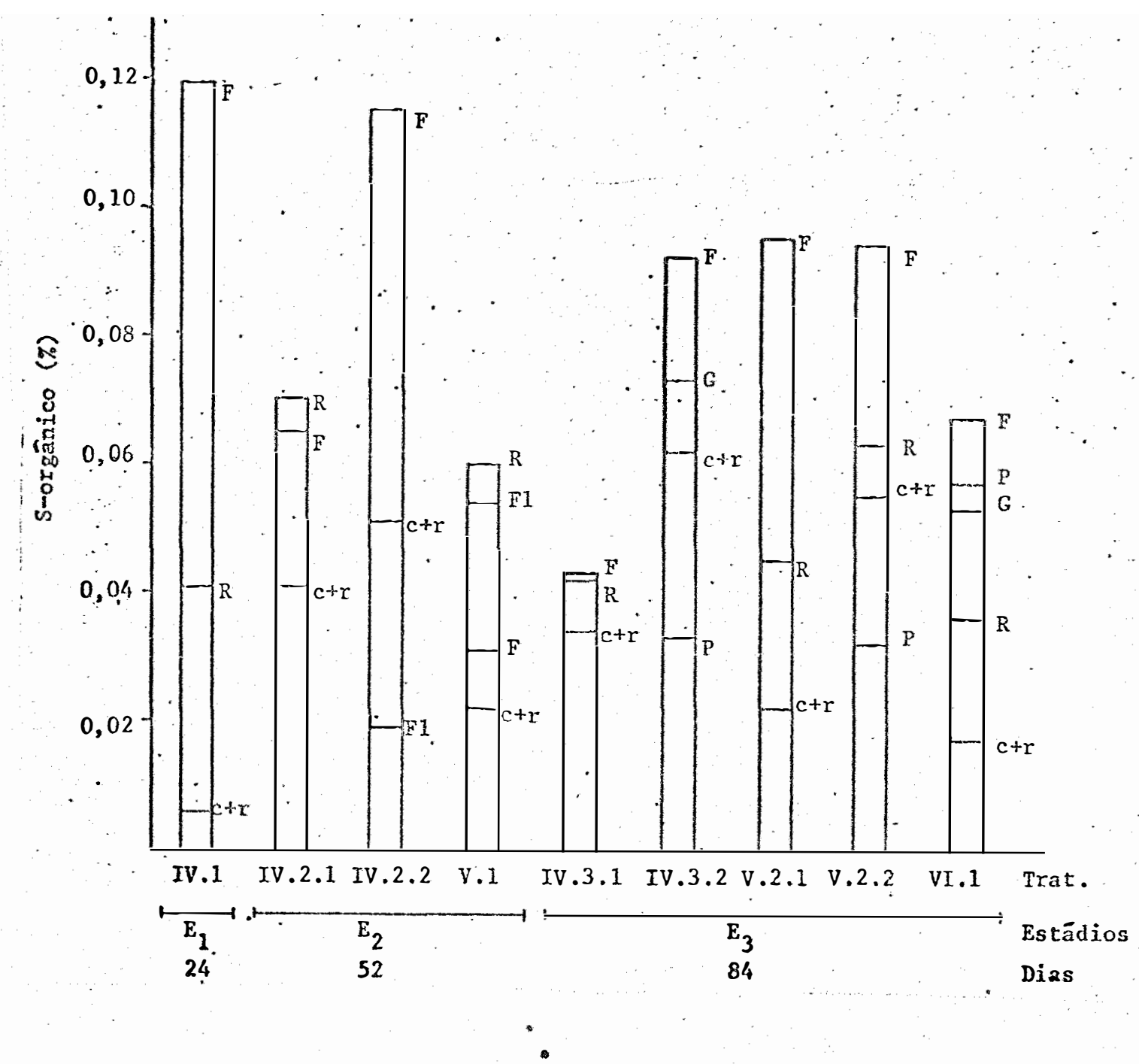

Figura 14 - Teor de S-orgânico nos diferentes órgãos do feí joeiro cultivado em solução nutritiva com deficiên cìa de $S$, em função dos estâdios de desenvolvimen to e do crescimento ocorrido apōs o 10 e $2 \%$ estâ dio, até o fim do ciclo. 
S para semelhantes estudos em feijoeiro.

Conclui-se pela discussão apresentada que este assunto se mostra bastante conflitante, uma vez que se o enxo fre se redistribui na forma de $\mathrm{S}_{-} \mathrm{SO}_{4}^{-}$, porque o mesmo não é for necido aos grãos em formação diretamente das raỉzes, notadamen te disponĩvel no tratamento s-completo? Qual seria a razão des te elemento ter que passar primeiro pelas folhas, sendo que elas redistribuem a mesma forma de enxofre $\left(\mathrm{S}_{-} \mathrm{SO}_{4}^{-}\right)$que tambẻm recebem diretamente das raïzes?

Como sugestão, podewse aventar a possibilidade de que a Forma de $\mathrm{s}$ redistribuido das folhas para as vagens venha a sex urn sulfatomorgânico, mais precisamente um éster de sulfa to, sendo conheciao a atividade da enzima arilsulfatose (E.C. 3.1.6.1.I em plantas, desde 1957 por Baum e Dodgson, alēm de outros trabalhos posteriores, conforme citado por SAMIULLAH e AFRTDI (19771, que detectaram a atividade desta enzima, que hi drolisa arilsulfatos liberando o $\mathrm{S}-\mathrm{SO}_{4}^{=}$em plantas de milho Zea mays (I..).

Estas enzimas, segundo o autor, são bastante ati vas em plantas, sugerindo a possibilidade de sua participação no papel de desulfação destes ésteres de sulfatos. Ainda, a mistura redutora do mētodo analítico empregado segundo JOHN SON e NISHI'A (1952), para análise do sulfato em plantas, re duz tanto as formas livres de $S$, como ésteres de sulfato e po lissacarídeos sulfatados.

Deste modo, fica bem claro a necessidade de mui 
55.

tos trabalhos a serem ainda realizados para se obter maiores esclarecimentos sobre toda a problemātica da redistribuição do enxofre em plantas. 


\section{CONCLUSÕES}

Em função da discussão apresentada em torno dos dados de produção dé matêria seca, grãos e das anälises quỉmi cas dos diferentes örgãos destas plantas nos teores de S-total, S-sulfato, s-orgânico e da atividade detectada devido à presen ça de ${ }^{35}$ S-total, tornou-se possîvel, nas condições do presente ensaio, concluir que:

a) O enxofxe sofre redistribuição, tanto em plan tas cultivadas em solução nutritiva completa como em solução nutritiva deficiente.

b) A redistribuição do $\mathrm{S}$ previamente absorvido foi maior no caso de plantas deficientes, entretanto, a quantidade total que sofreu redistribuição foi maior em se tratando de plantas do tratamento completo.

c) A māxima redistribuição do enxofre, ocorreu na época da formação de grãos, que concentrou a maior fração do s-redistribuido e que fora proveniente das folhas adultas, que por sua vez, se apresentaram como os principais örgãos en 
volvidos no processo de redistribuição do enxofre.

d) Durante o ciclo completo do feijoeiro, a fra ção máxima de $S$ redistribuido ocorreu entre $\circ 29$ e 39 estádio para ambos os tratamentos, que apresentaram valores entre 40 a 60\% do total absorvido. Entre o 10 e 28 estãdio este valor fí cou em torno de $30 \%$ e ocorreu principalmente de folhas adultas para as folhas novas, formadas neste perỉodo.

el O enxofre se redistribui nestas plantas, na sua forma inorgânica, muito provavelmente como sulfato, embora, este fato, terha sido possivel observar apenas nas plantas do tratamento completo. 
58.

6. LITERATURA CITADA

ALIAWAY, W.H. e THOMPSON, J.F. 1966. Sulfur in the nutriti on of plants and animals. Soiz Sci., I01 (4):240m247.

ALMEIDA, D.L.; ROCHA, A.C.M.; FIRA, P.A.; PACOVA, E.E.V. E SU HEn, A.R. 1972. Aăbagäo mireral do feijoeiro (phasoorus vulgaris, L.) baseada na análise de solos dos estados do Rio de Janeiro e Espirito Santo. In: VII Reunião Brasilei ra de Fertilidade do Solo, Itabuna, BA, Sociedade Brasilei ra de Ciêncía do Solo.

BIDDULPH, O.; CORY, R. E BIDDUIJP, S. 1956. The absorption and transiocation of sulfur in red kidrey bean. Plant Phy siol., $3 I: 28-33$.

BLAIR, G.J.; FERNANDO, G.W.E.; CROFTS, F.C. e CARTER, O. G. 1970. The influence of temperature on the growth and sul fur uptake of oats (Avena sativa, I.). Comm. in Soil Sci. and Plant Analysis, I(2):115-122.

BIAIR, G.J. 1971. The sulphur cycle. J.Aust. Inst. Agric. Sci., 113-121. 
BOUMA, D. 1967. Nutrient uptake and distribution in subter ranean clover during recovery from nutritional stresses. Aust. J. Biol. Sci, 20:613-621.

EATON, S.V. 1951. Volatile sulphur content of black mustar ce plants. Bot. Gaz., 104:82-89.

EPPENDORFER, W.H. 1971. Effects. of S, N and P on amino acid composition of field beans (Vicia faba) and responses of the biological value of the seed protein to s-amino acid content. J. Sci. Fd. Agric.,22:501-505.

ERGLE, D.R. 1954. Utilization of storage sulfur by cotton and the effect on growth and chloroplast pigments. Bot, Gaz., $\underline{1} 15: 225-234$.

GALIJO, J.R. e MJYASAKE, S. 1961. Composiç̃̃o quimicà do fei joeiro e absorção de elementos nucrituvos, do floxescimen to à maturação. Bragantia, 20 (40):867-884.

GILBERT, F.A. 1951. The place of sulfur in plant nutrition. The Bot Rev., ].7(9):671-691. New York.

HPAG, H.P.; MALAVOLTA, E.; GARGANTINI, H. e GARCIR BLANCO, H. 1967. Absorção de nutrientes pela cultura do feijoej ro. Bragantia, 26(30):381-391.

HARRISON, B.F.; THOMAS, M.D. e HILL, G.R. 1944 . ... Radioauto graphs showing the distribution of sulphur in wheat. Plant Physiol., 19:245-257.

HARWOOD, J.L. e NICHOLLS, R.G. 1979. The plant sulpholipid - a major component of the sulfur cycle. Biochem. Soc. Transactions, $\underline{7}: 440-447$. 
INGELSTEN, B. 1966. Absorption and transport of sulfate by wheat at varying mannitol concentration in the medium. Physiol. Plant, 19:563-579.

JOHNSON, C.M. e NISHITA, H. 1952. Microestimation of sulfur in plant materials, soils and irrigation waters. Anal. Chem., 24:736-742.

JORDAN, H.V. e ENSMINGER, L.E. 1958. The role of sulfur in soil fertility. Adv. Agron., 10:407-434.

KYLIN, A. 1953. The uptake and metabolism of sulphate by deseeded wheat plants. Physiol. Plants 6 :775-795.

KYLIN, A. 1960. The incorporation of radio-sulphur from ex ternal sulphate into different sulphur fractions of isola ted leaves. Physiol. Plant, 13:366-379.

KXIIN, A. 1966. The effect of light, carbon dioxide, and ni trogen nutrition on the incorporation of $S$ from external sulphate into different s-containing fractions in scenedes mus with special reference to lipid s. Physiol. Plant, $\underline{19}: 883-887$.

LAUCHLI, A. 1972. Translocation of inorganic solutes. Ann. Rev. Plant Physiol., 23:197-218.

LINZON, S.N. 1972. Effects of sulphur oxides on vegetation, The Forestry Chronicle, $48(4): 1-5$.

LIPMANN, F. 1958. Biological sulfate activation and trans fer. Science, $128: 575-580$.

LOPEZ, A.S. e QUESNEL, V.C. 1976. Methyl-S-methionine sul phonium salt: a precursor of dimethyl sulphide in cacao. 
J. Sci, Fd, Agric, ,27:85-88.

MALAVOLTA, E. 1952. Estudos químicos agrícolas sobre o enxo fre. Anais da Escola Superior de Agricultura "Luiz de Que $\underline{i}$ roz", $\underline{9}: 39-130$.

MALAVOLTA, 1971. Nutrição e adubação. Anais do I Simposio Brasileiro de Feijão, Campinas, 22-29 de agosto, p-211-242. MALAVOLTA, E. 1975. Práticas de Nutrição Mineral de Plantās do Curso de Pós-Graduação em Solos e ivutxição de Plantas, ESALQ/USP, Piracicaba, SP, 65 p. (Mimeo.).

MIMIER, D.S. e NAISMITI, D.J. 1958. A correlation between sulphur content and net dietary-protein value. Nature, 382: 1786 .

NETIO, A.C.; ACCORSI, W.R. e MALAVOLTA, E. 197l. Estudos sobre a nutrição minexal do feijoeiro (Phaseolus vulgaris, L., var. Roxinho\}. Anais da ESALQ, 28:257-274. NIGHTINGALE， G.T.; SCHERIERHORN, L.G. e ROBBINS, W.R. 1932. Effects od sulphur deficiency on metabolism in tomato. Prant Physiol., I (4):565-595.

PATTERSON, M.S. e GREENE, R.C. 1965. Measurement of low energy beta-emitters in aqueous solution by liquid scintil lation counting of emulsions. Anal. Chem., 37:854-857. PEITERSON, S. 1960. Ion aboorption in young sunflower plants. I - Uptake and transport mechanisms for sulfate. Physiol. Plant., 13:133-147. PETTERSON, S. 1966a. Active and passive components of sulfa te uptake in sunflower plant. Physiol. Plant, 19:459-492. 
PETTERSON, S. 1966b. Artificially induced water and sulfate transport through sunflower roots. Physiol. Plant,19:581601

PORTER, W.M.; MANER, J.H.; AXTELL, J.D. e KEIM, W.F. 1974. Evaluation of the nutritive quality of grain legumes by an analysis for total sulfur. Crop Sci., 14:652-654. SAMIULLAH, A.A.F. e AFRIDI, M.M.R.K. 1977. Arylsulphatase ac tivity of corn (Zea mays, L.) seedling roots. Planta, 133: $157-160$

STUBBS, R.D. 1973. Liguid scintillation. counting. In: FAI RES; R.A. e PARKS, R.H. ed. Radioisotope Laboratory Tech niques. $\quad 3$ a ed, London, Butterworth, cap. 17; p. 209 31.

TABATABAI, M.A. e BREMMER, J.M. A simple turbidimetric me thod of determining total sulfur in plant materials. Agron. $J \cdot, \underline{62}: 805-806$.

TERRY, N. 1976. Effects of sulfur on the photosynthesis of intact leaves and isolated chloroplasts of sugar beets. plant Physiol., $57(4): 477-479$.

THOMAS, M.D.; HENDRICKS, R.H. e HILL, G.R. 1944a. Some che mical reactions of sulphur dioxide after absorption by al fafa and sugar beets. Plant Physiol.,19:212-226.

THOMAS, M.D.; HENDRICKS, R.H*; BRYNER, L.C. e HILL, G. R. 1944b. A study of the sulphur metabolism of wheat, bar ley and corn using radioactive sulphur. Plant Physiol., $19: 227-244$.

THOMAS, M.D.; HENDRICKS, R.H. e HILL, G.R. 1950. Sulfur Me 
tabolism in alfafa. Soil sci., $70(1): 19-26$.

THOMPSON, J.F. 1967. Sulfur metabolism in plants. Ann. Rev. Plant Physiol., (18):59-84.

TOLBERT; N.E. e WIEBE, H. 1955. Phosphozus and sulfur com pounds in plans xilem sap. Plant Physiol., 30:499-504.

WIEBE, H.H. e WIHRHEIM, S.E. 1962. The influence of inter nal moisture stress on translocation. In: Radioisotopes in Soir. Plant Nutrition Studies. Ed. International Atomic Energy Agency. Viena. p.279.

WITSOR, I.G. 1962. Metabolim of sulfate: sulfate reduction. Ann. Rev. Plant physioz, 13:201-224.

WOOD, J.G. 1942. Metabolisin of sulphur in plants. Cronica Botanica, $7(1): 1-4$.

ZIEGLER, I. 1975. The exfects of $\mathrm{SO}_{2}$ pollution on plant rie tabo1ssm. Res. Rev., 55:79m105. 
64.

A $P$ E N D C E 
Tabela 10 - Produção de matéria seca de feijoeixo cultivado em solução nutritiva com concentrações crescentes de $S$, colhido na época inicial da formação de vạ gens (47 dias).

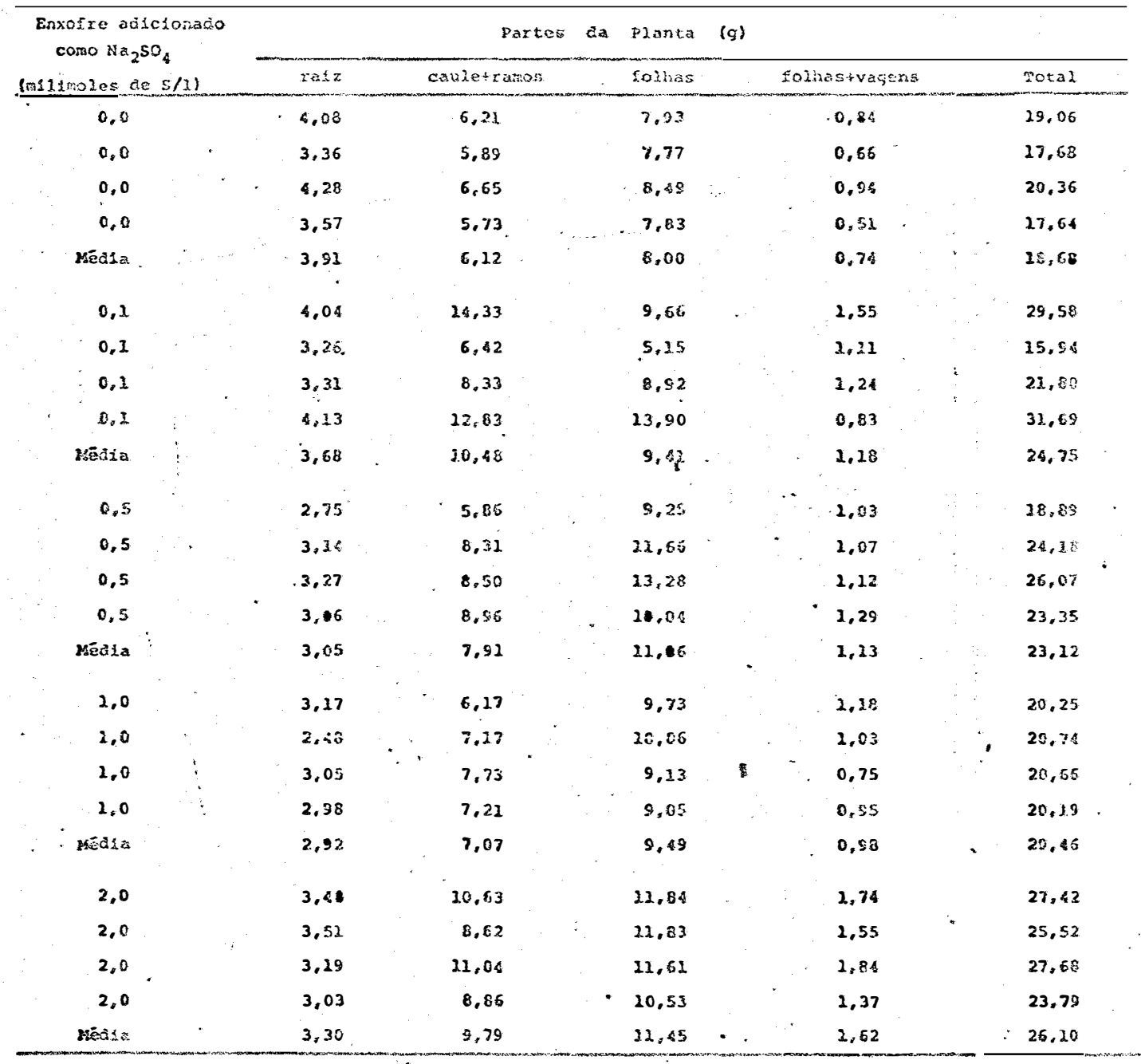


Tabela 11 - Teor de $\mathbf{S - t o t a l ~ n a ~ m a t e ́ r i a ~ s e c a ~ d e ~ f e i j o e i r o ~ c u l ~}$ tivado em solução nutritiva com concentrações crescentes de $s$, colhido na época inicial de for mação de vagens ( 43 dias):

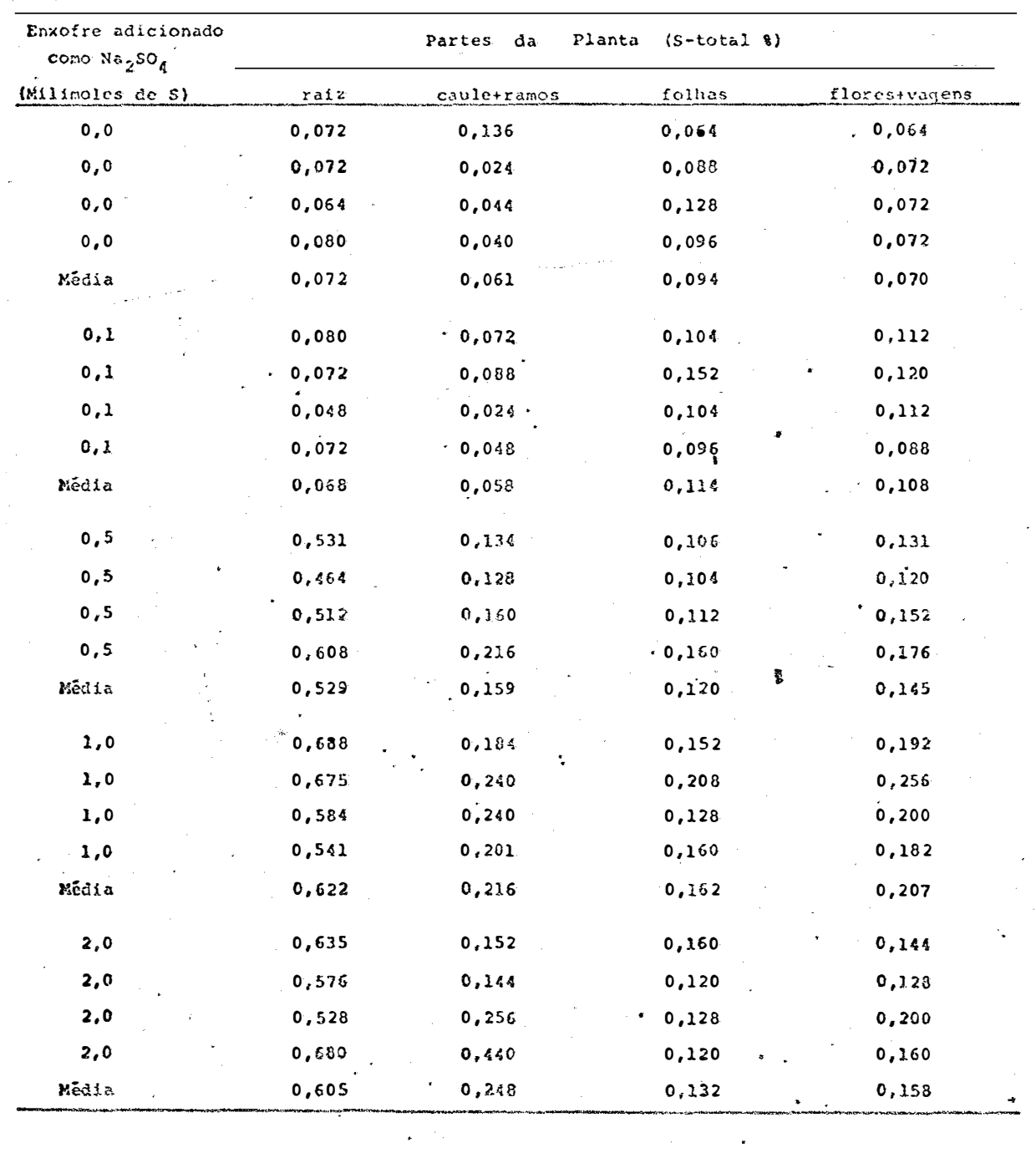




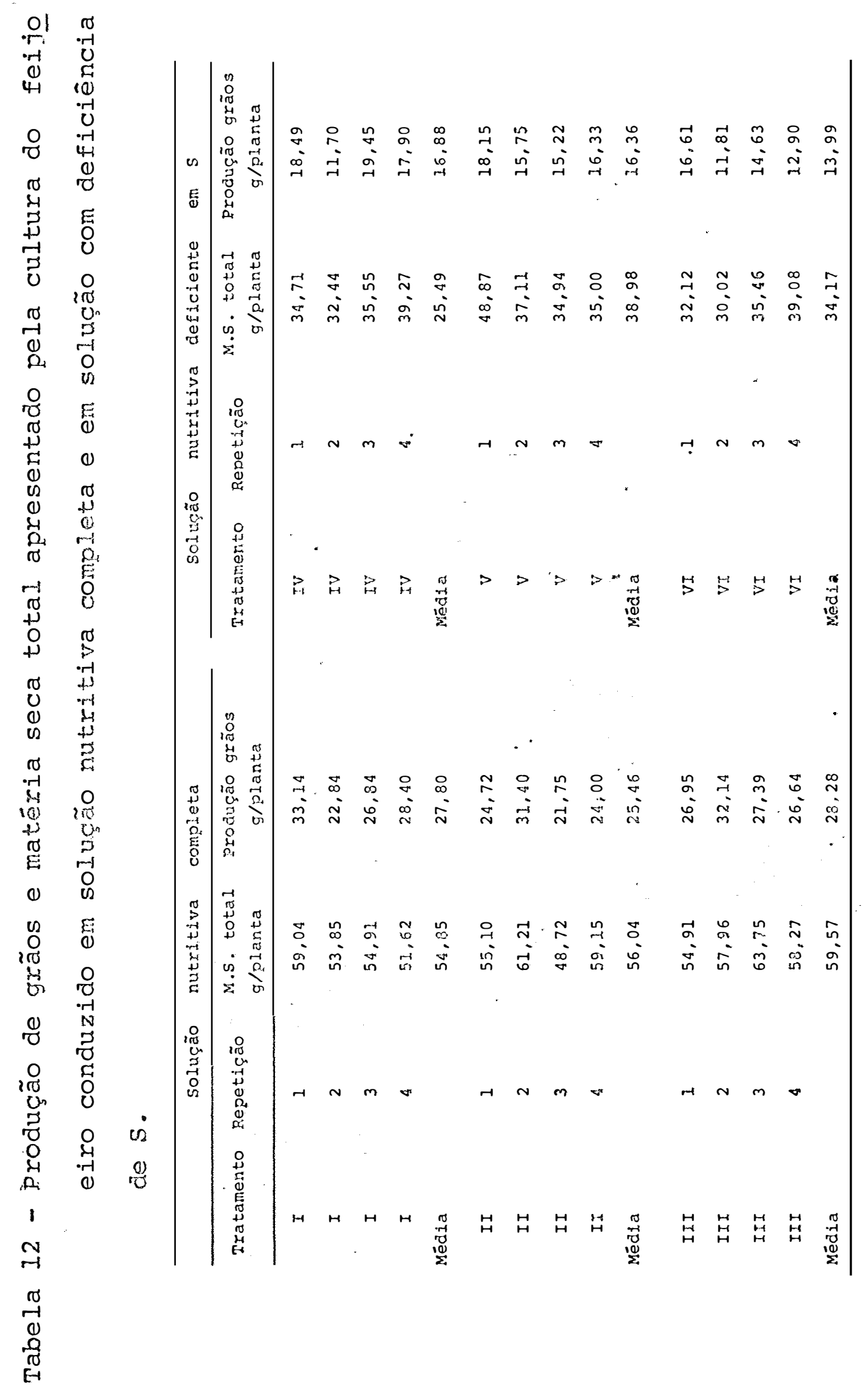


68.

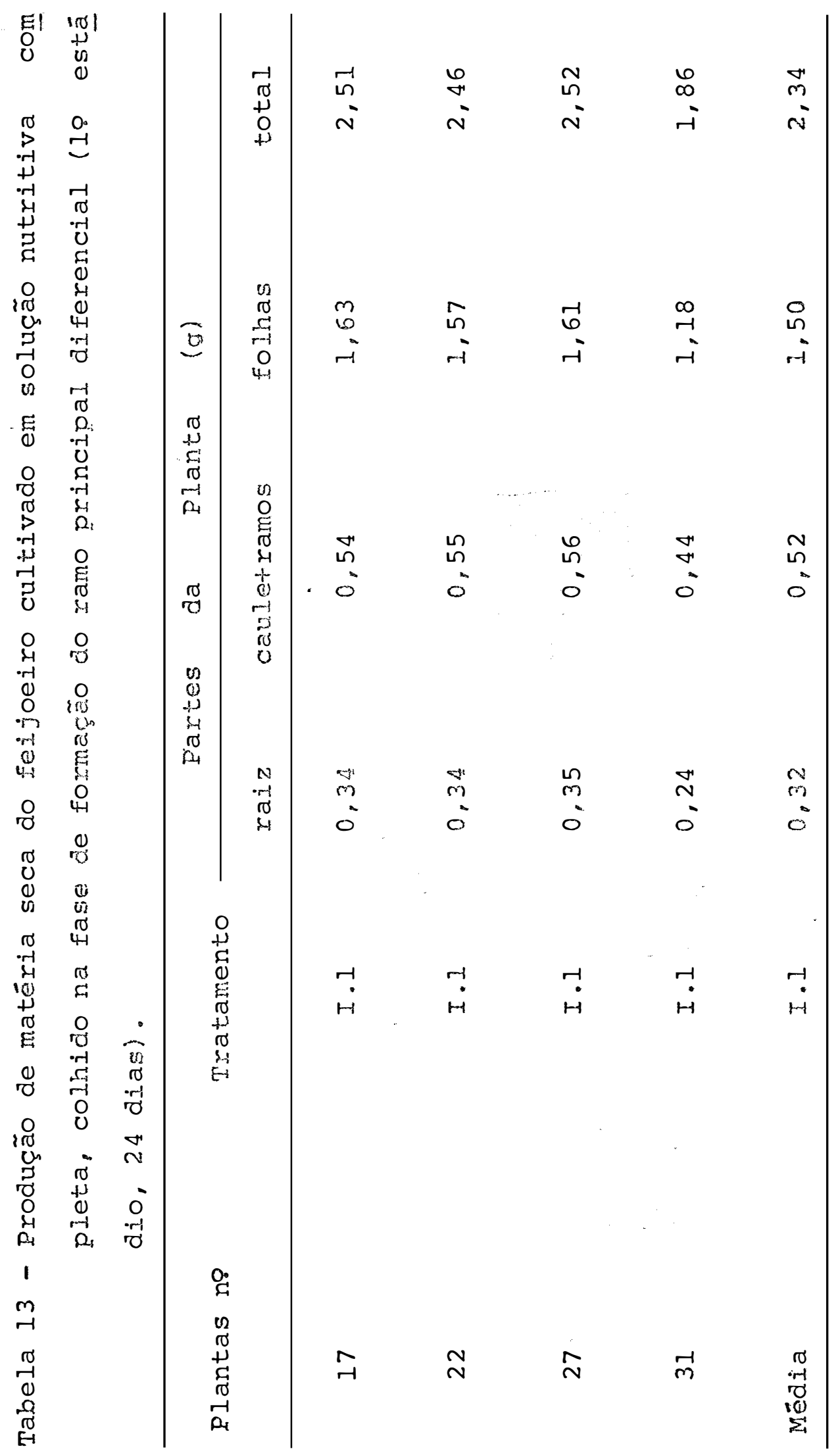




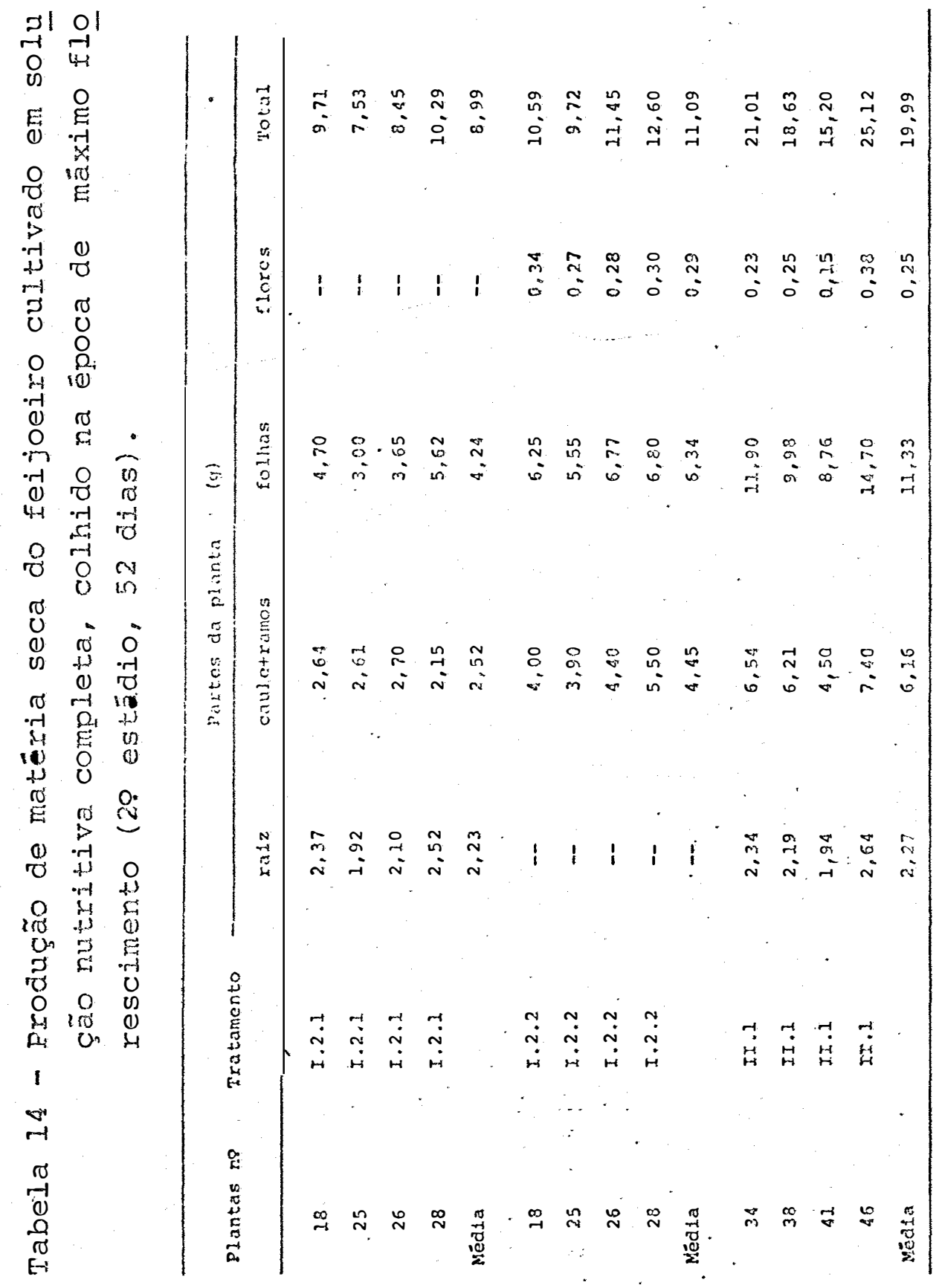


Tabela 15 - Produção de matéria seca do feijoeiro culti vado em solução nutritiva completa, colhido na época de fim de ciclo (84 dias).

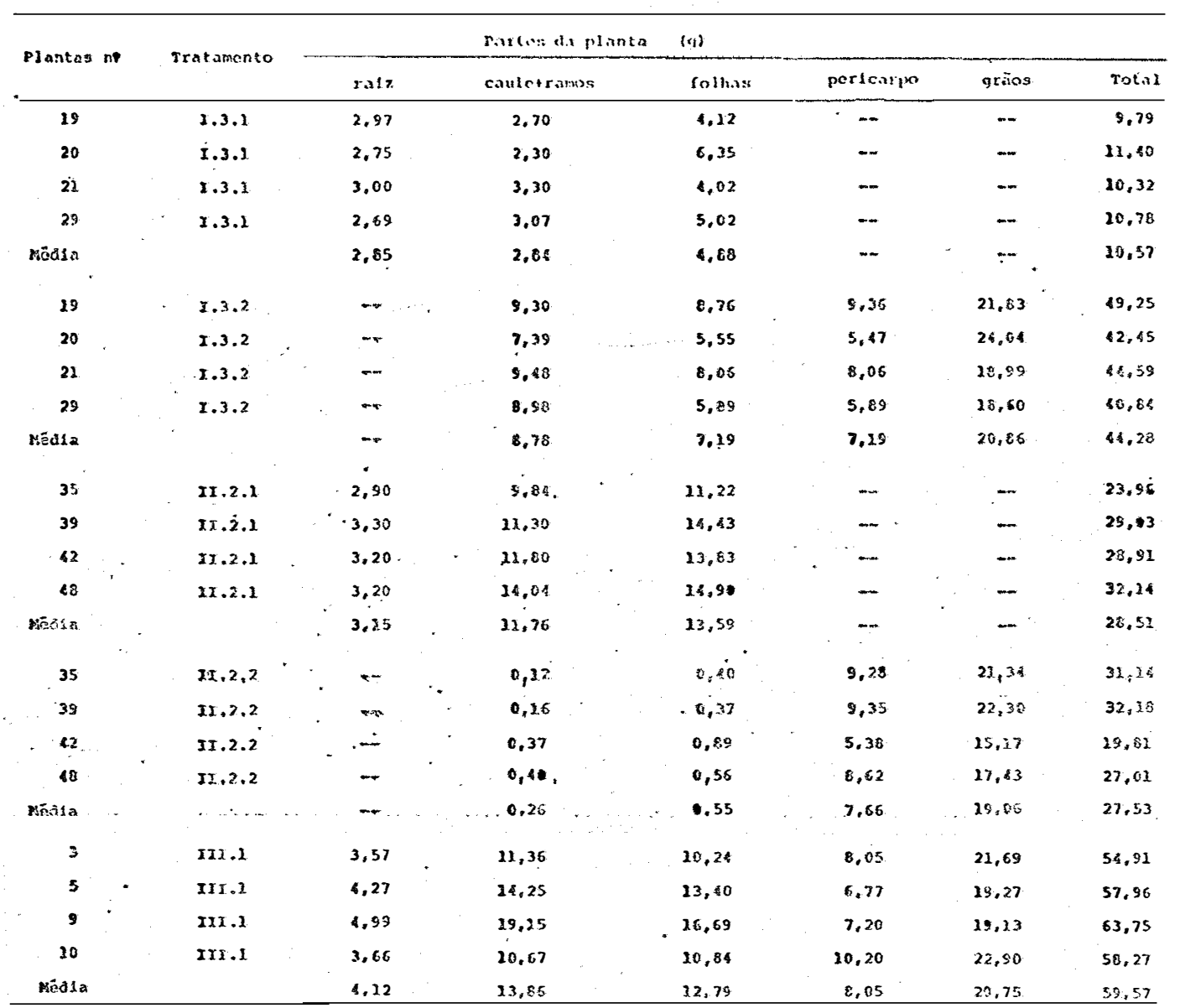




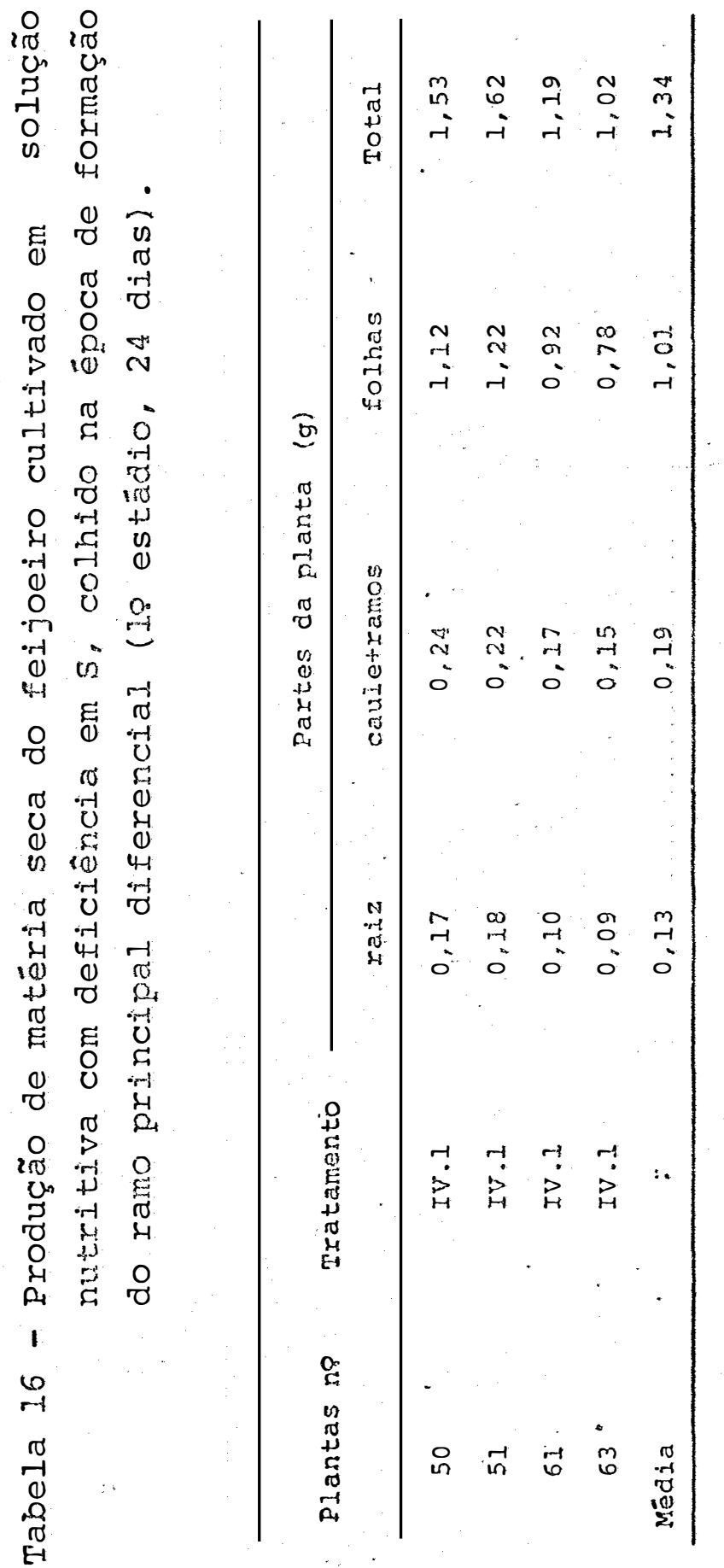




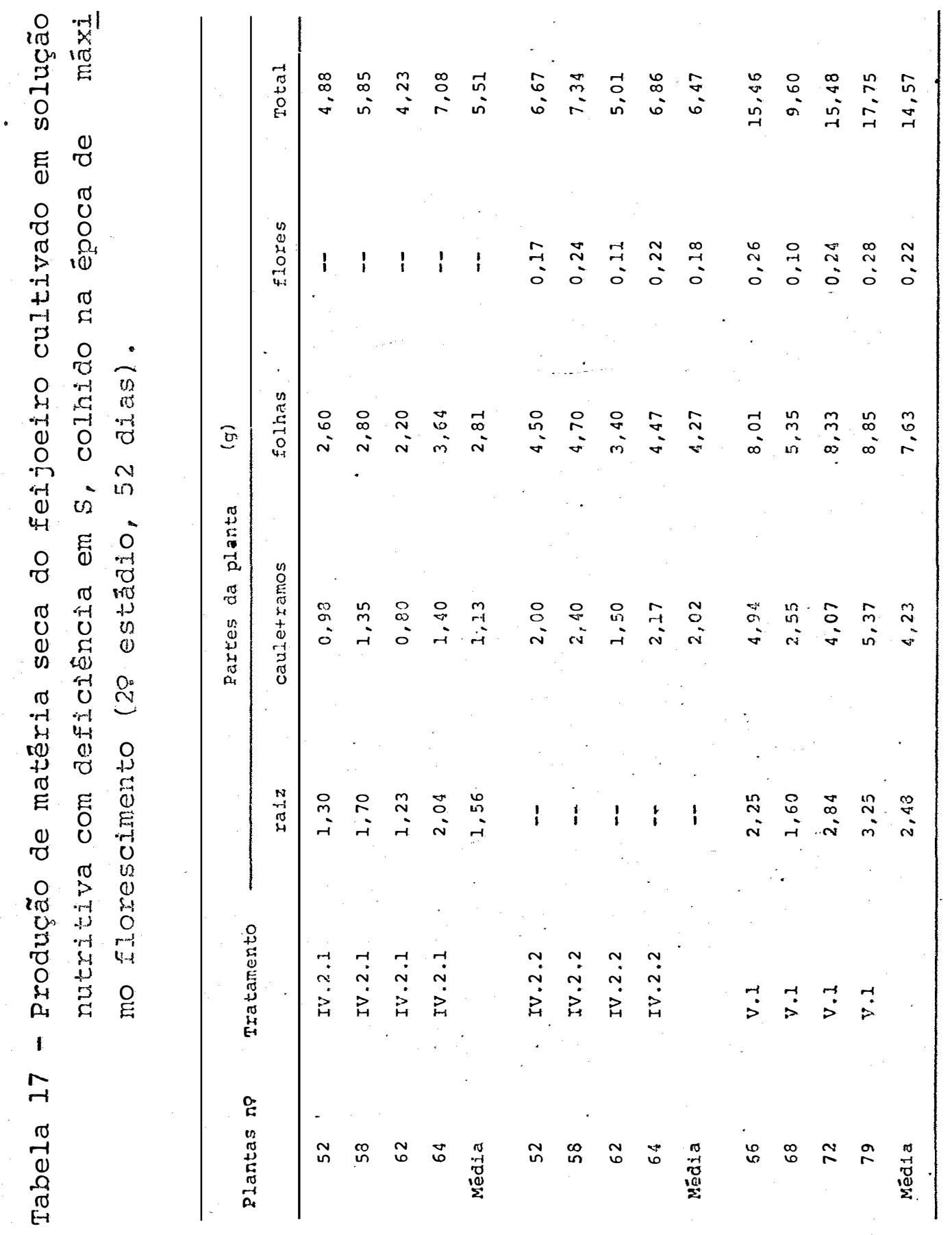


Tabela 18 - produção de matêría seca do feijoeiro culti vado em solução nutritiva com deficiência em $S$, colhido na êpoca de fim de ciclo (84 diasl.

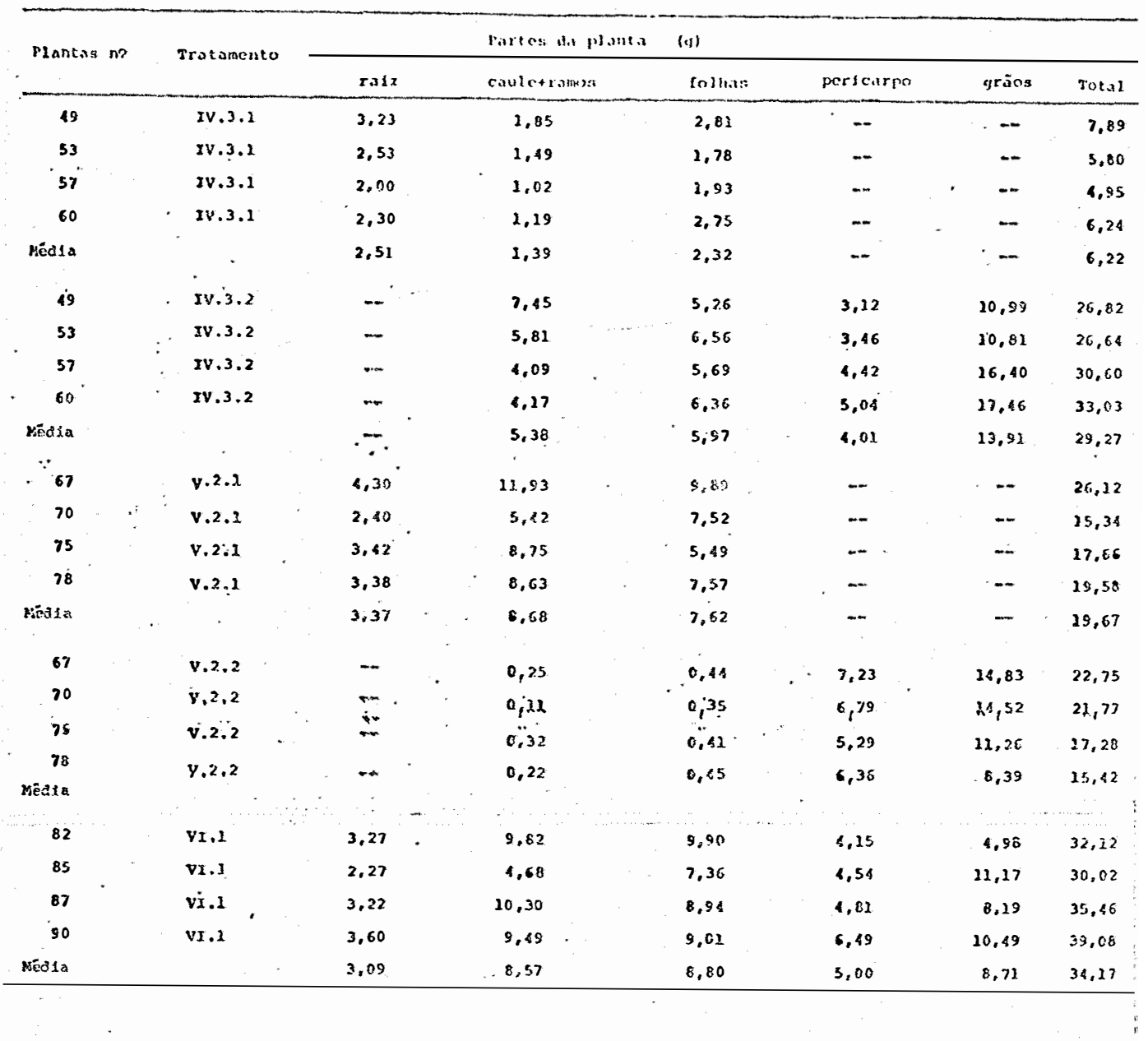




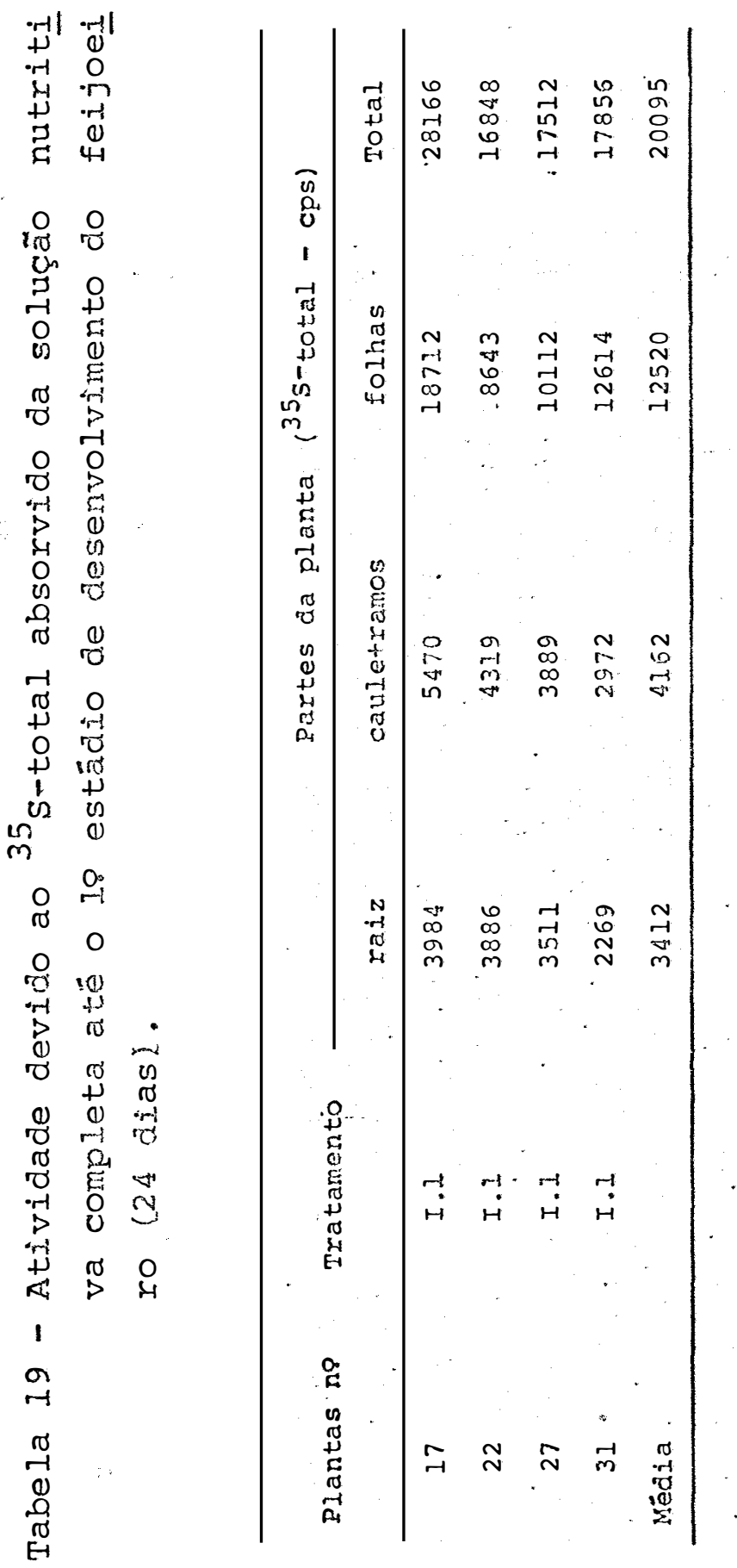




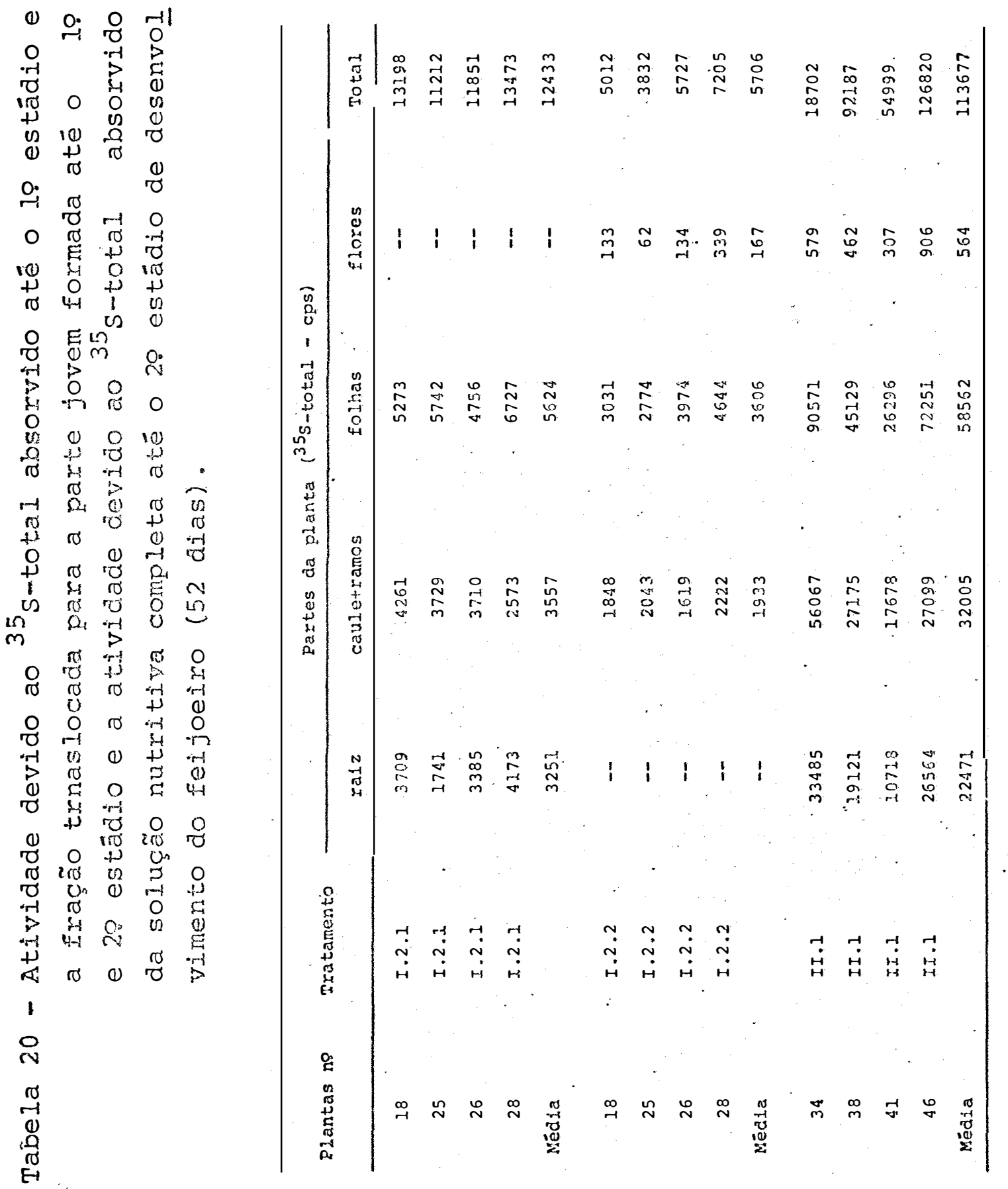


Tabela 21 - Atividade devido ao ${ }^{35}$ S-total absorvido atê o 19 e 29 estádio e a fxação translocada para a parte mais jovem que se formou posteriormente atê 030 está dio e ao ${ }^{35}$ S-total absorvido da solução nutritiva completa atē o 39 estâdio" de desënvolvimento " "do feijoeiro (84 dias).

\begin{tabular}{|c|c|c|c|c|c|c|c|c|c|c|c|c|}
\hline \multirow{2}{*}{ Plantas } & \multirow{2}{*}{ ne } & \multirow{2}{*}{\multicolumn{2}{|c|}{ Tratamento }} & \multicolumn{9}{|c|}{ Purtes din plantes $\left({ }^{35} s-t n t a l-c p s\right)$} \\
\hline & & & & $x a l z$ & & couletramos & & folha: & & perscarpo & grāos & Total \\
\hline 19 & & 1.3 .2 & & 2602 & & 2594 & & 2031 & & -- & - & 7227 \\
\hline 20 & & $x .3 .1$ & & 2387 & & 2868 & & 3420 & - & $\cdots$ & - & 8665 \\
\hline 21 & & 1.3 .1 & & 3675 & & 3290 & & 1962 & & - & $\ldots$ & 8927 \\
\hline 29 & & 1.3 .2 & & 2412 & & 3060 & $\cdots$ & 3163 & & - & - & 8642 \\
\hline Hédsa. & & $\because$ & & $27 \varepsilon 9$ & & 2935 & & 2641 & & $\cdots$ & - & 8365 \\
\hline 19 & . & $x .3 .2$ & & - & & 2632 & & 4252 & & 2096 & 5021 & 13901 \\
\hline 20 & & 1.3 .2 & & -- & & 2409 & & 1521 & & 2335 & 5577 & 20842 \\
\hline 21 & & 1.3 .2 & & -- & & 2327 & & 2610 & & 1314 & 5374 & 10425 \\
\hline 29 & & I.3.2 & & - & & 1176. & & 2270 & & 1602 & 4445 & 9493 \\
\hline $\begin{array}{l}\text { Média } \\
\because \quad .\end{array}$ & $\cdot$ & & & $-\infty$ & & 1886 & & 2588 & & 2587 & 5108 & 33265 \\
\hline 35 & & $\pi x .2 .2$ & & 20897 & & $2 \$ 718$ & & 24676 & & $\cdots$ & $\ldots$ & CO291. \\
\hline 39 & $\cdot$ & $\pi x .2 .2$ & & 24179 & & 24510 & & 18802 & & - & - & 67491 \\
\hline 62 & $\therefore$ & $3 x .2 .2$ & & 08298 & 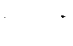 & 18105 & . & 23967 & . & $\cdots$ & - & 50370 \\
\hline 48 & & II.2.2 & & 21603 & & 25258 & . & 15660 & . & - & - & 62521 \\
\hline Béd1a & & & & 18714. & & 23148 & & 18276 & & - & - & 60168 \\
\hline 35 & & $x \pi .2 .2$ & & $\cdots$ & $\cdot$ & 241 & & 231 & & 08723 & 50554 & 59532 \\
\hline$\because \quad 39$ & & $I x .2 .2$. & & $m$ & $\cdot$ & 208 & & 385 & & 20724 & 94666 & 55803 \\
\hline . $\quad 32$ & . & $\pi x .2 .2$ & & $\therefore$ & & $38 \sigma$ & 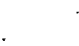 & 189 & . & 05837 & 24059 & 30465 \\
\hline 48 & & $5 x .2 .2$ & & $\cdots$ & & 338 & & 931 & & 05870 & 39880 & 47019 \\
\hline Mždta & & . & & $\therefore$ & & $\therefore 242$ & & 405 & & 2789 & 39740 & 88225 \\
\hline 3 & & III.1. & & 40526 & & 32542 & & 19773 & & 34961 & 85003 & 212777 \\
\hline 5 & $\therefore$ & $\operatorname{IIx} .2$ & & 63243 & & 40997 & & 222818 & & 29659 & 50198 & 206381 \\
\hline 9 & $\because$ & III.2. & & 62195 & & 52452 & & 25788 & & 21853 & 87892 & 230178 \\
\hline$\because \quad 10$ & & III.I & & 45029 & & 29193 & & 19447 & & 32273 & 78501 & 204443 \\
\hline Nëàa & & & & 52746 & & 38791 & & 21823 & & 29687 & 70399 & 213445 \\
\hline
\end{tabular}




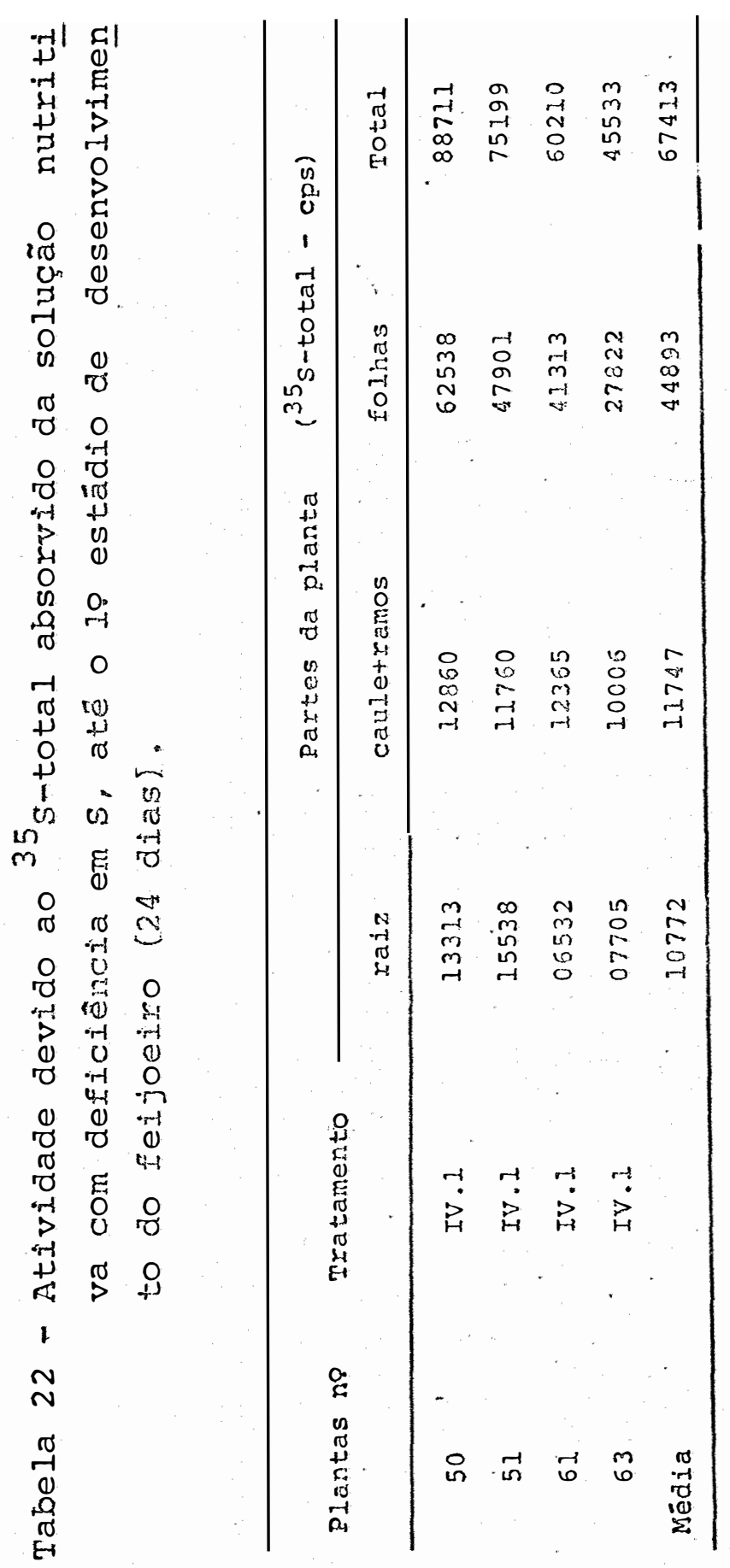




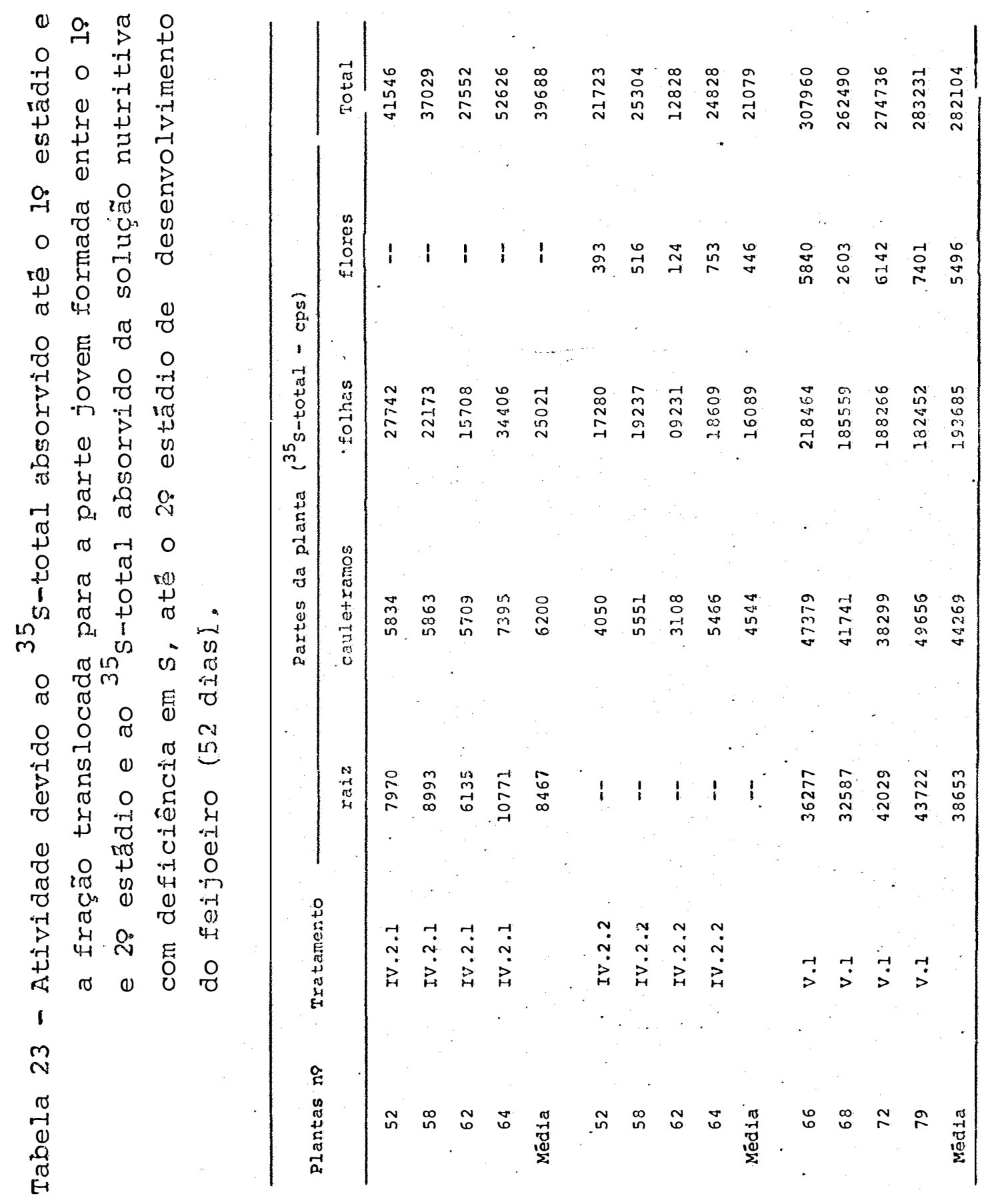


Tabela 24 - Atividade devido ao ${ }^{35}$ S-total absorvịdo até - 19 e $2 \%$ estădio e a fração translocada pa ra a parte mais jovem que se formou poste riormente atë 0 3) estádio e ao ${ }^{35}$ s-total ab sorvido da solução nutritiva com deficiên cìa em $\mathrm{S}$ atê o 3 o estädio de desenvolvimen to do feijoeiro (84 dias).

\begin{tabular}{|c|c|c|c|c|c|c|c|c|c|}
\hline \multirow{2}{*}{ Plantas } & & \multirow{2}{*}{ gratamento } & \multicolumn{5}{|c|}{ 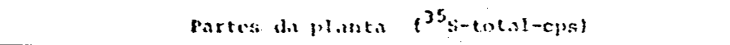 } & \multirow[b]{2}{*}{ grños } & \multirow[b]{2}{*}{ Tolas } \\
\hline & & & rasz & & caule+ranniusi & Sollins & pertcarpo & & \\
\hline 49 & $\cdot$ & Iv.3.1 & 6243 & & 2534 & 33314. & $-\cdots$ & - & 22091 \\
\hline 53 & & IV.3.1 & 0324 & & 2819 & 09688 & - & - & 12831 \\
\hline 37 & & xv.3.1 & 4186 & & 2948 & 32983 & - & - & 20117 \\
\hline 60 & & IV.3.1 & 5297 & & 1353 & 121.27 & - & - & 26807 \\
\hline Mëdia & & $\therefore$ & 1012 & & 2421 & 22020 & - & $\ldots$ & 18461 \\
\hline 49 & & . $1 V .3 .2$ & $\cdot-\cdots$ & & 2734 & 51.65 & 1189 & 27588 & 26872 \\
\hline 53 & $\because$ & Iv. 3.2 & - & & 0895 & 1686 & 0.315 & 14226 & 17122 \\
\hline 57 & & Iv.3.2 & - & & 2552 & 5724 & 3542 & 25125 & $3 \div 943$ \\
\hline 60 & $\cdot$ & 20.3 .2 & - & & 2323. & 7225 & 2063 & 22523 & 36132 \\
\hline Mēôla & & & - & 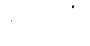 & 2125 & 495 & 2277 & 19864 & 2823.7 \\
\hline 67 & & v.2.2 & 33662 & . & 58689 & 72672 & $\cdot-$ & $-\cdots$ & 244983 \\
\hline yo & & v.2.1 & 21437 & & 16920 & 55551 & $-\infty$ & $-\cdots$ & 36898 \\
\hline 25 & & $v .2 .1$ & 25373 & & $2927 \%$ & 80357 & - & - & 95007 \\
\hline 78 & & v.2.x & 24598 & & - 29825 & 73164 & - & - & 127585 \\
\hline Mẹeara & & . & 26257 & 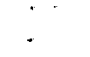 & 28675 & 61186 & - & - & $31 \varepsilon 118$ \\
\hline 67 & & v.2.2 & - & $\therefore$ & $58 x$ & 0516 & 15053 & 022652 & 37702 \\
\hline 70 & & $\forall .2 .2$ & $m$ & : & $\therefore 207$ & 0926 & 26819 & 230283 & 148240 \\
\hline 78 & & 8.2 .2 & $\ldots$ & . & 294 & 1257 & 14315 & 227598 & 143464 \\
\hline 78. & & v.2.2 & - & & 262 & 2822 & 26140 & 083497 & 112720 \\
\hline Médía & & & $\therefore$ & & $331 \ldots$ & 1130 & 18082 & .90759 & 220302 \\
\hline 82 & & $v x .1$ & 64484 & . & 155136 & 219443 & 43320 & 147094 & 62.9977 \\
\hline BS & & $\mathrm{Vx} .1$ & 45171 & & 070520 & 209407 & 34794 & 292207 & 651289 \\
\hline 87 & & $y x-1$ & 60082 & & 039043 & 204556 & 47479 & 138640 & 539800 \\
\hline 90 & & $v x \cdot 1$ & 61128 & & 070710 & 263333 & 55632 & 127149 & 477952 \\
\hline Mēasa & & & 57716 & & 96325 & 199185 & 45431 & 176272 & 574929 \\
\hline
\end{tabular}




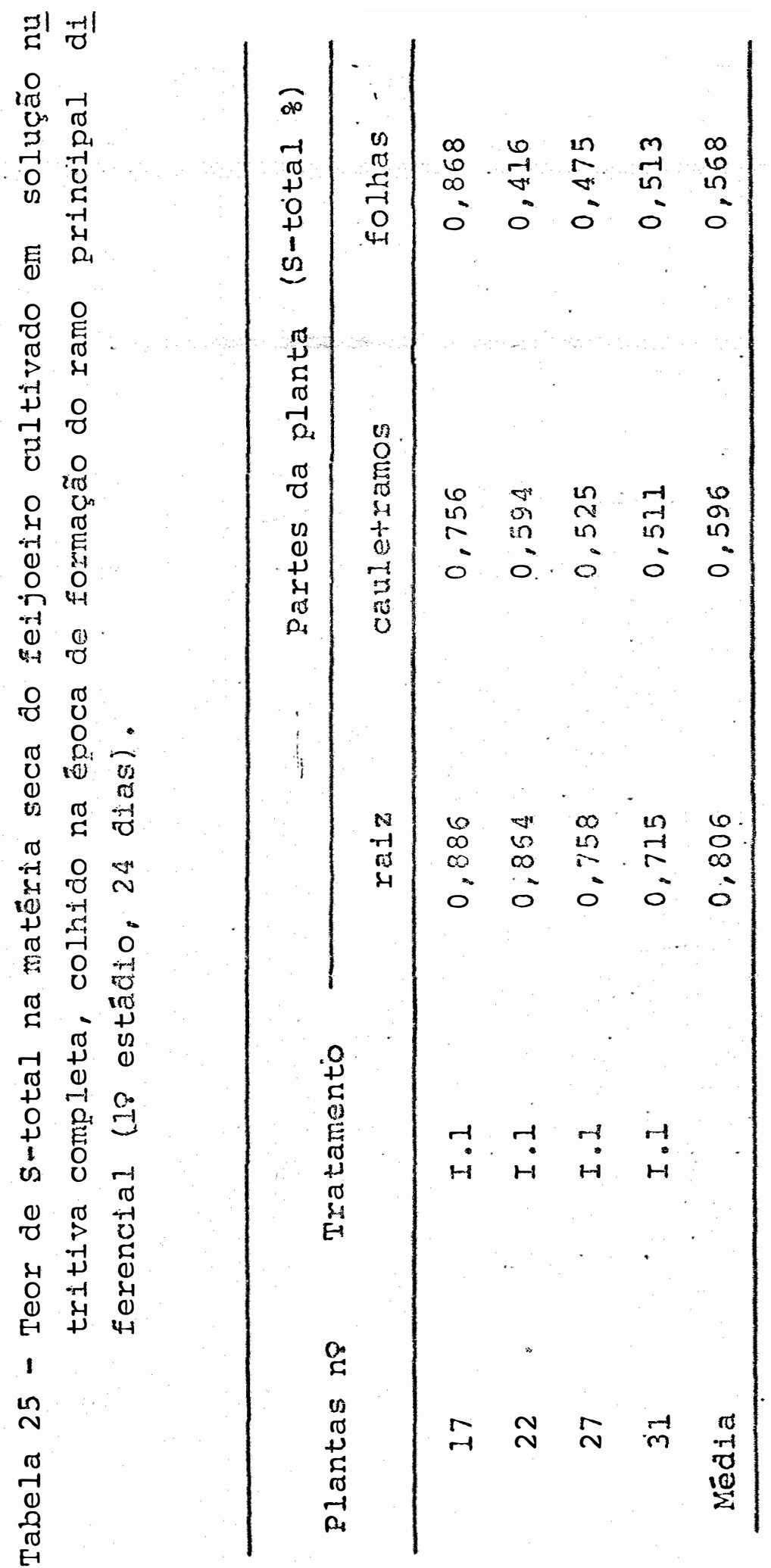




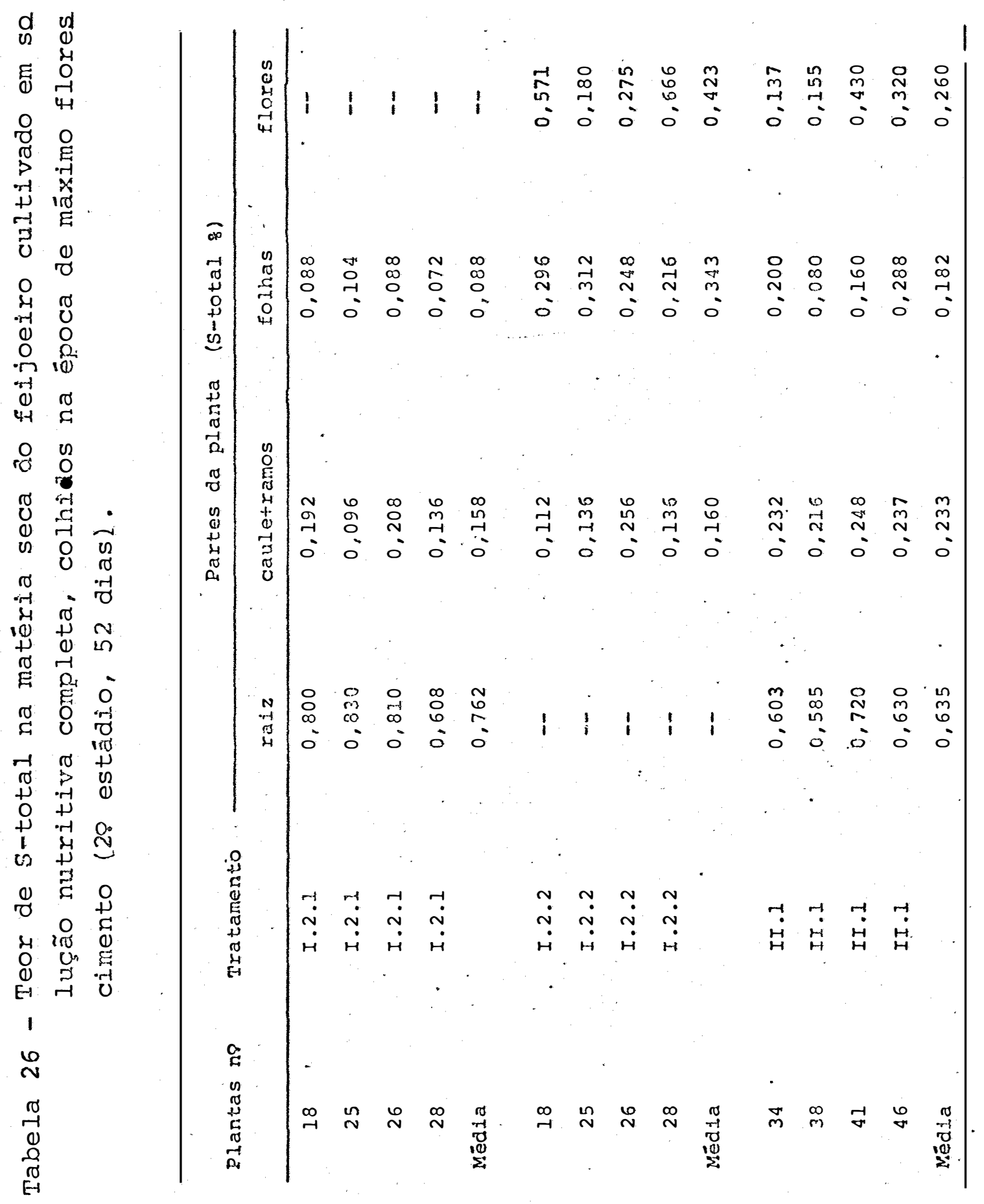


Tabela 27 - Teor de S-total na matéria seca do fei. joeirro cultivado em solução nutritiva completa, colhido na êpoca de fim do ciclo ( 84 dias).

\begin{tabular}{|c|c|c|c|c|c|c|}
\hline \multirow{2}{*}{ Plantas no } & \multirow{2}{*}{ Tratamento } & \multicolumn{4}{|c|}{ rurtos; do plunt: (s-tot.11 3$)$} & \multirow[b]{2}{*}{ grīos } \\
\hline & & xalz & couler rances & folhas & pevicirpo & \\
\hline 29 & 1.3 .1 & 0,600 & 0,144 & 0.088 & - & - \\
\hline 20 & 1.3 .1 & 0,456 & 0.276 & 0.096 & - & - \\
\hline 21 & 1.3 .1 & 0.542 & 0,200 & 0.080 & - & - \\
\hline 29 & 1.3 .1 & 0.640 & 0,184 & 0.080 & - & - \\
\hline rêdia & . & 0.559 & 0,176 & 0,086 & - & - \\
\hline 29 & $x .3 .2$ & $-\cdots$ & 0,088 & 0,248 & 0.204 & 0.080 \\
\hline 20 & 1.3 .2 & -- & 0.056 & 0.088 & 0,088 & 0,204 \\
\hline 21 & 1.3 .2 & $-\cdots$ & 0,204 & 0.096 & 0.088 & 0.070 \\
\hline 29 & 1.3 .2 & - & 0.088 & 0.096 & 0.112 & 0,070 \\
\hline . Mêdia & . & $=$ & 0,084 & 0,132 & 0,098 & 0,081 \\
\hline . 35 & $x x .2 .1$ & $0,639^{\circ}$ & 0.104 & 0.056 & $\cdots$ & -- \\
\hline 39 & 12.2 .1 & 0.585 & 0,088 & 0,088 & - & - \\
\hline 42 & $I I: 2.1$ & 0.641 & 0.088 & 0,144 & - & - \\
\hline 48 & $x x .2 .1$ & 0,776 & 0.088 & 0,104 & -- & - \\
\hline Média & . & 0,660 & 0.092 & $0,098$. & -- & - \\
\hline 35 & 11.2 .2 & + & 0,143 & .0 .207 & 0,040 & 0,136 \\
\hline 39 & $2 x .2 .2$ & $\rightarrow$ & 0,055 & $0.132^{\circ}$ & $0,02 \varepsilon$ & 0,228 \\
\hline .42 & $2 \pi .2 .2$ & $m p$ & 0,203 & 0.095 & 0.050 & 0.151 \\
\hline rẵáa & 31.2 .2 & 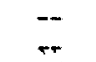 & $\begin{array}{l}0,080 \\
0,205\end{array}$ & $\begin{array}{l}0,058 \\
0.105\end{array}$ & $\begin{array}{l}0,016 \\
0,058\end{array}$ & $\begin{array}{l}0,336 \\
0,138\end{array}$ \\
\hline 3 & III.1 & 0,536 & 0,096 & 0.104 & 0,095 & 0,143 \\
\hline 3 & IXI.x & 0.624 & 0.080 & 0.080 & 0.080 & 0,151 \\
\hline 9 & $2 x x .1$ & 0.584 & 0,088 & 0.104 & 0.203 & 0,172 \\
\hline 20 & IIT.1 & 0,584 & 0,088 & 0.104 & 0,097 & 0,103 \\
\hline Hêda & & 0.582 & 0,088 & 0,098 & $0.09 \varepsilon$ & 0,142 \\
\hline
\end{tabular}




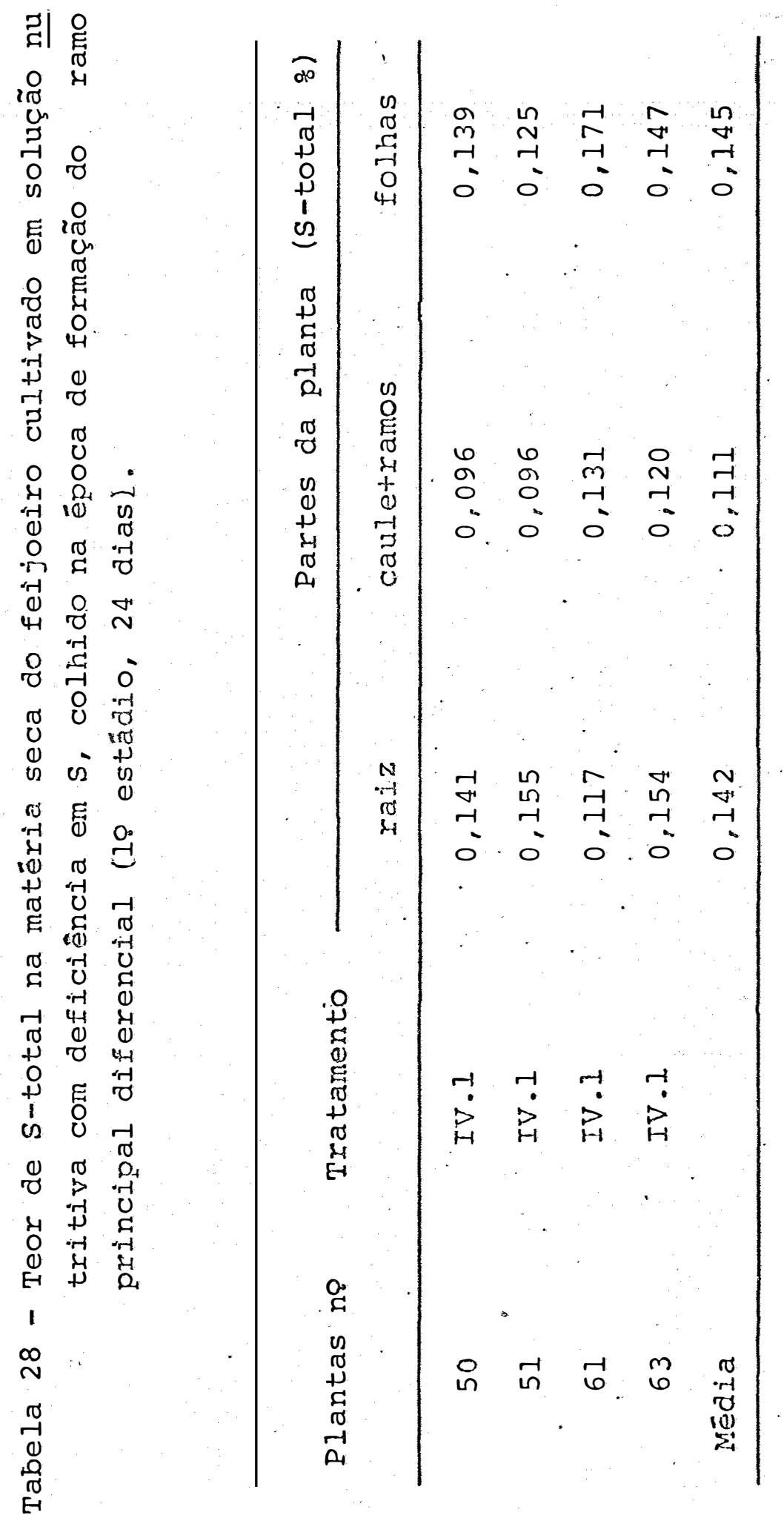




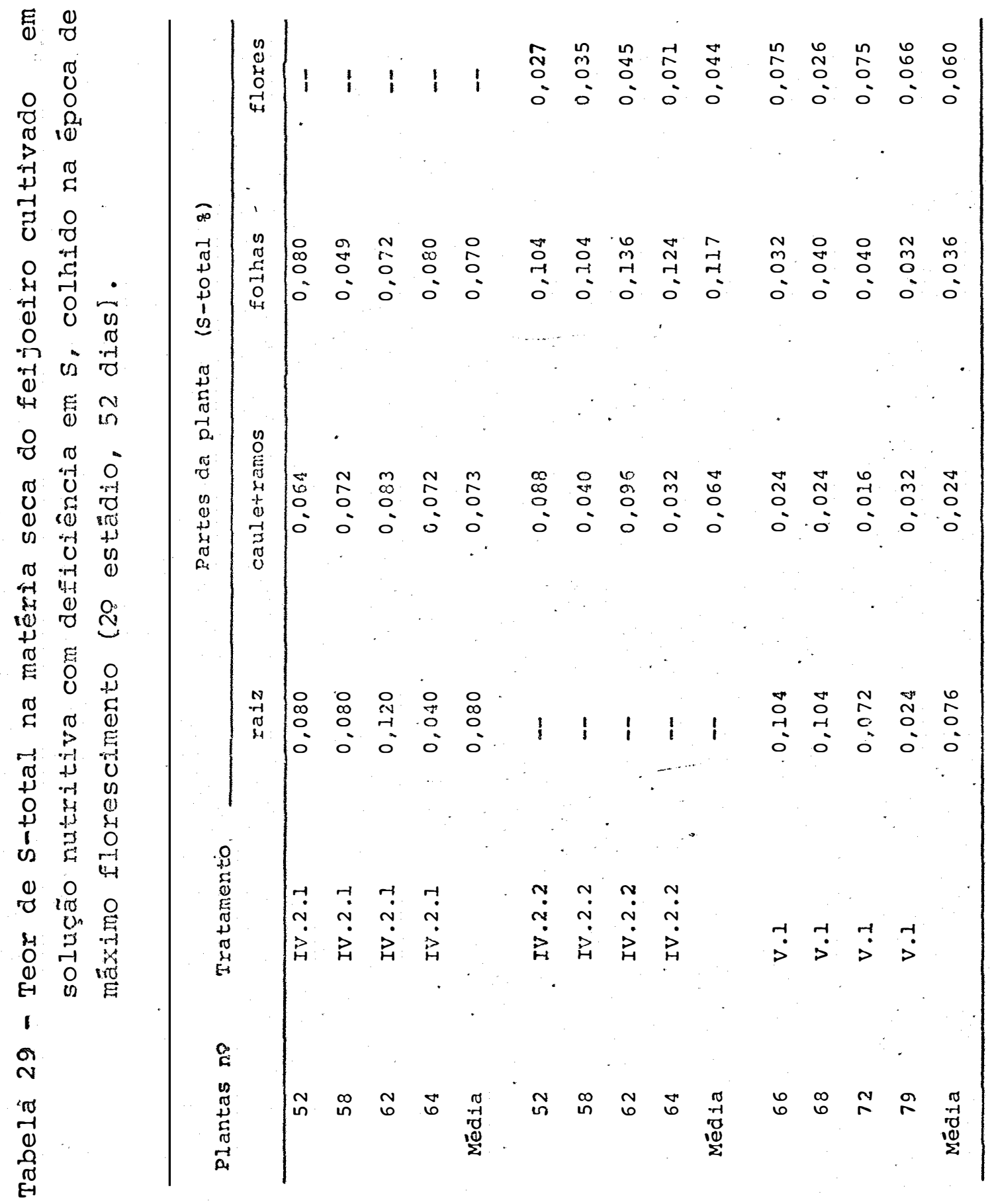


Tabela 30 - Teor de S-total na mâteria seca do fei joeixo cultivado em solução nutritiva com deficiência em $S$, colhido na êpoca de fim de ciclo (84 dias).

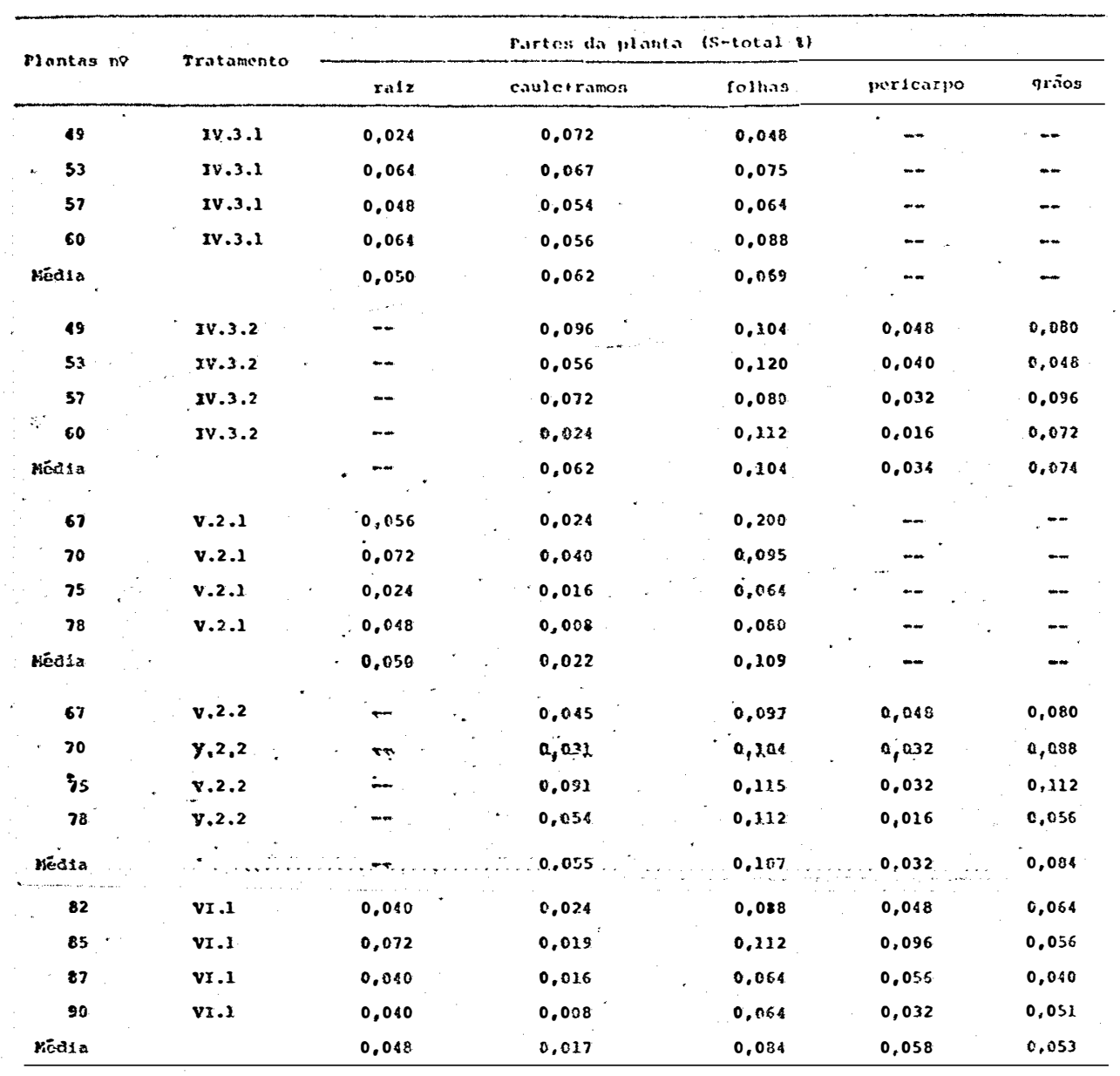




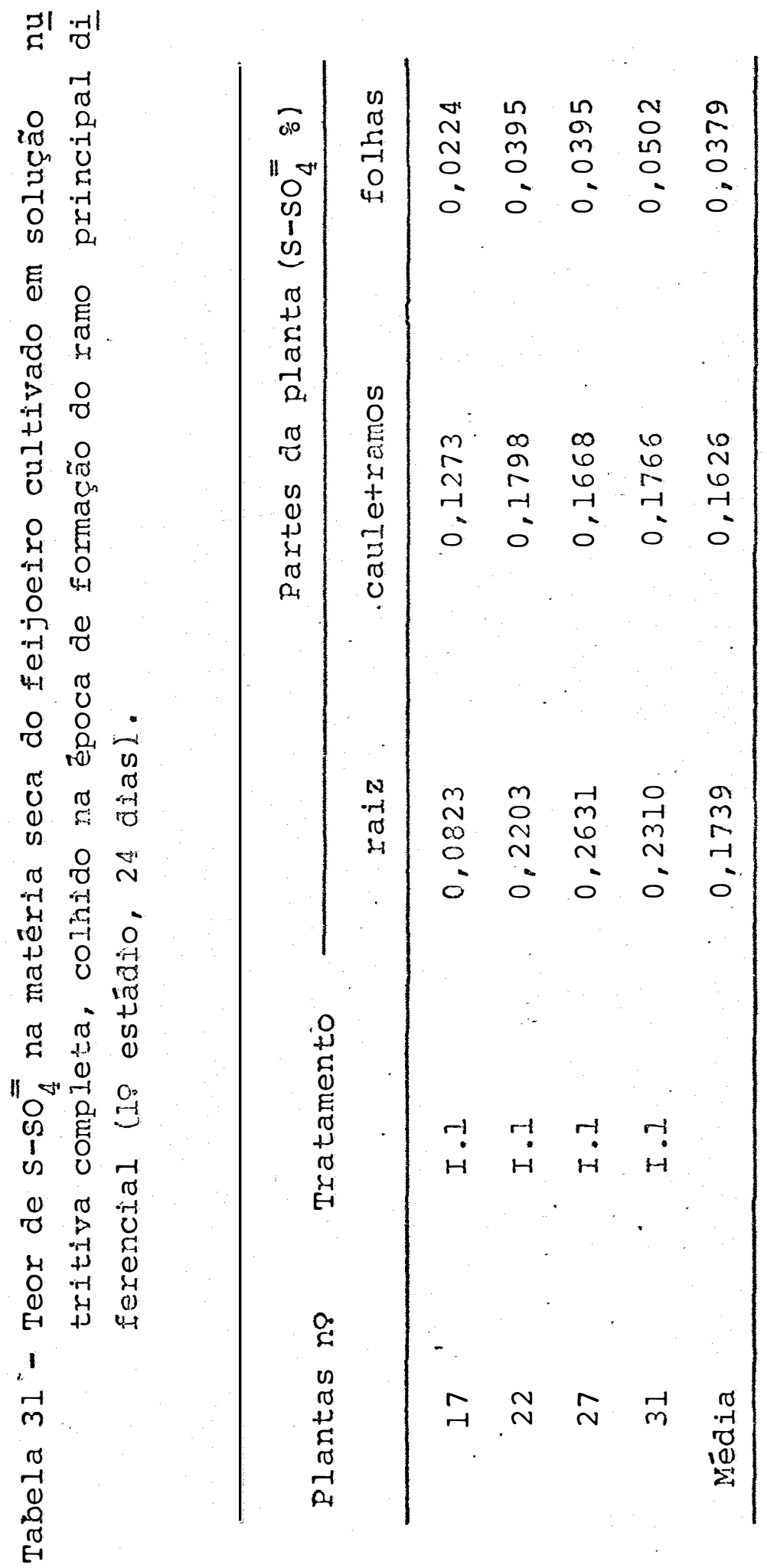




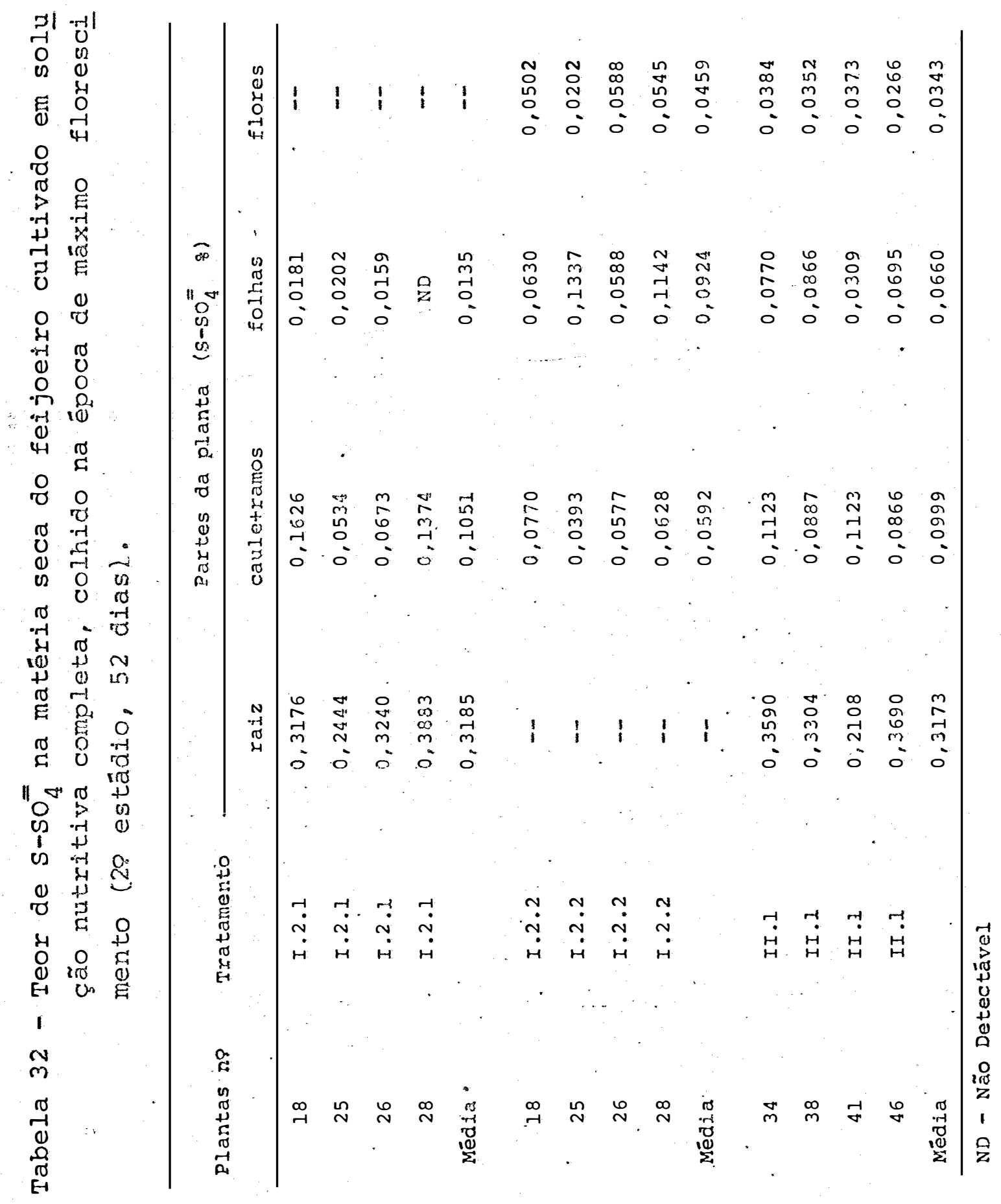


Tabela 33 - Teor de $\mathrm{S}_{\mathrm{SO}}=\mathbf{4}$ na matêria seca do feijoei ro cultivado em solução nutritiva comple ta, colhido na época de fim de ciclo (84 diasl.

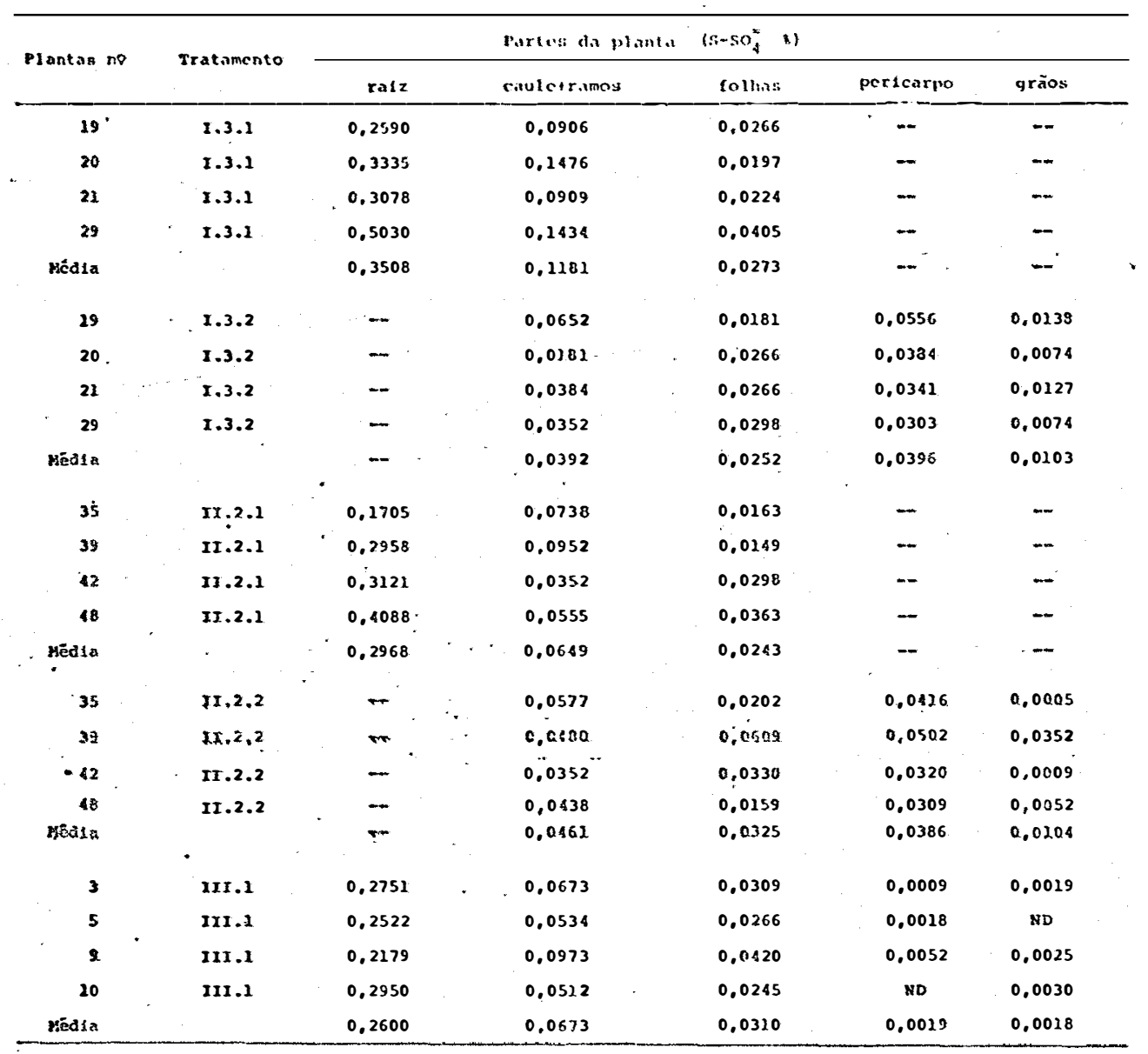

MD * xăo Detectável. 


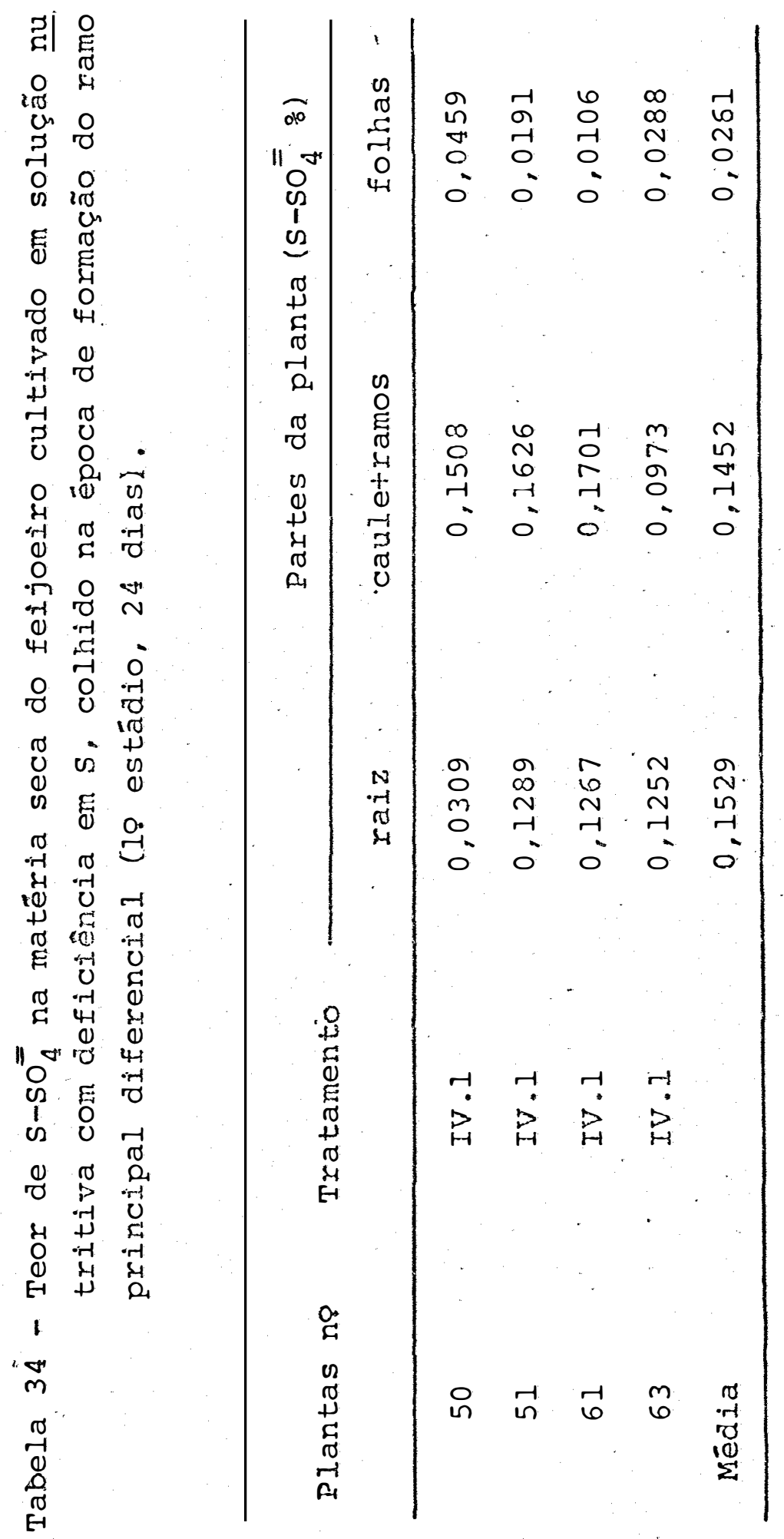




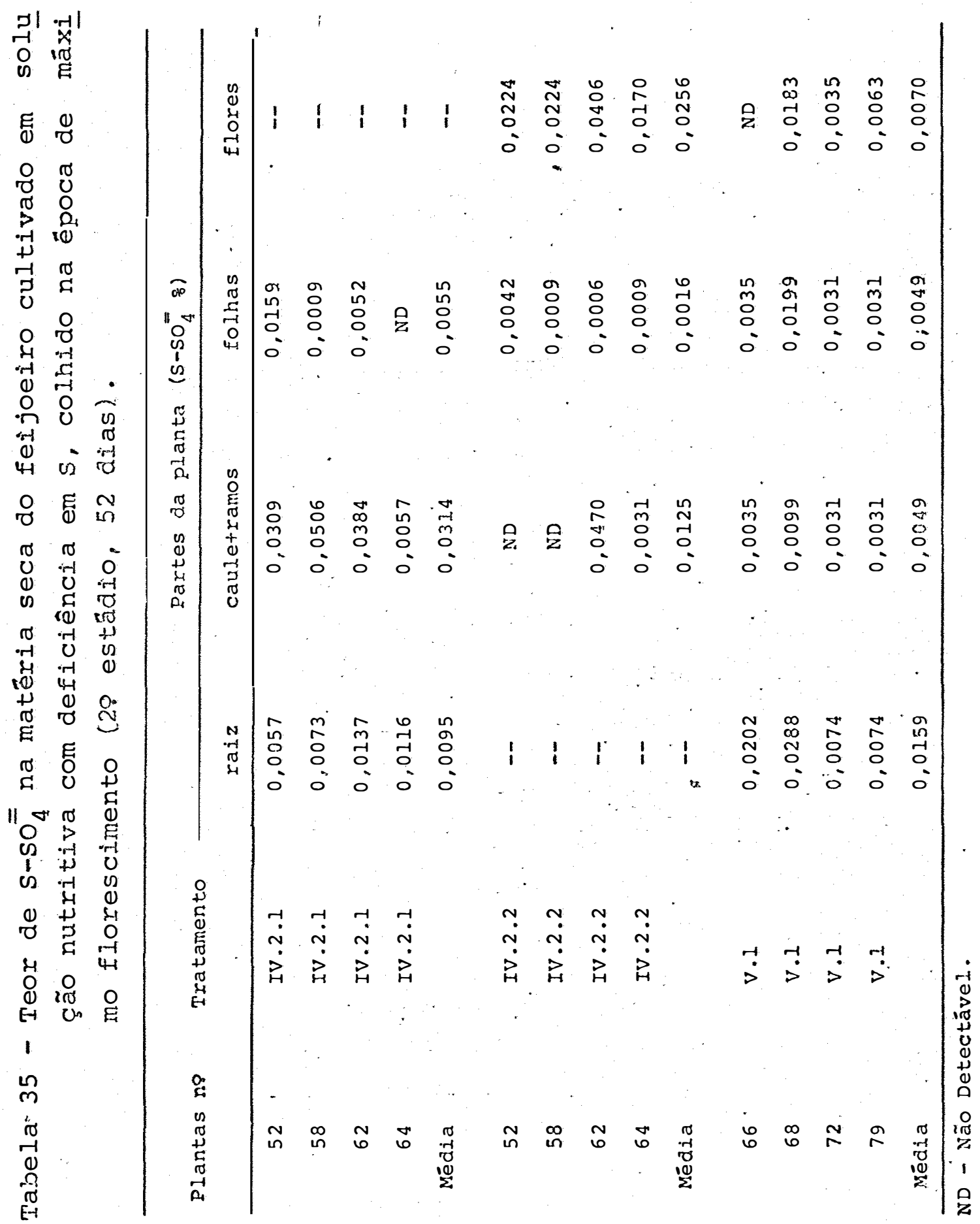


Tabela 36 - Teor de $\mathrm{S}_{-\mathrm{SO}_{4}}=$ na matéria seca do feijoei ro cultivado em solução nutritiva com de ficiência em $S$, colhido na época de fim de ciclo (84 diasl.

\begin{tabular}{|c|c|c|c|c|c|c|}
\hline \multirow{2}{*}{ Plantas ne } & \multirow{2}{*}{ Trataniento } & \multicolumn{4}{|c|}{ Portest d., mant. $\left(5-\mathrm{SO}_{4}\right.$, $)$} & \multirow[b]{2}{*}{ grãos } \\
\hline & & $x a 12$ & cauletranos & follus & pericaryo & \\
\hline 49 & 20.3 .2 & 0,0052 & 0.0309 & 0.0094 & - & - \\
\hline 53 & $2 v .3 .1$ & 0.0009 & ND & 0.0256 & - & $\cdots$ \\
\hline 57 & Iv.3.1 & 0,0181 & 0.0245 & 0.0395 & - & $\cdots$ \\
\hline 60 & IV.3.1 & 0,0031 & 0.0636 & 0,0341 & $\cdots$ & $\cdots$ \\
\hline Média & & 0,0068 & 0.0297 & 0.0271 & - & -- \\
\hline 49 & IV.3.2 & $\ldots$ & ND * & 0,0138 & ND & 0,0009 \\
\hline 53 & IV.3.2 & - & ND & 0,0170 & 0,0042 & ND \\
\hline 57 & IV.3.2 & - & 0,0009 & 0.0352 & ṆD & 0,0009 \\
\hline 60 & IV.3.2 & -- & ND & 0.0224 & ND & ND \\
\hline MẼdla: & & $\cdots:$ & 0,0002 & 0.0221 & 0,0010 & 0,0004 \\
\hline 67 & v.2.1 & 0,0084 & ND & 0.0137 & - & -- \\
\hline 70 & v.2.1 & 0.0095 & BD & 0.0256 & - & - \\
\hline 75 & $v .2: 1$ & 0.0020 & ND & 0.0105 & - & - \\
\hline 78 & v.2.1 & ND & ND & 0,0084 & .- & - \\
\hline Media & . & 0,0049 & ND & 0,0145 & -- & - \\
\hline 67 & v.2.2 & $\because$ & ND & 0.0281 & ND & ND \\
\hline 20 & $y, 2,2$ & $a$. & HD & 0.0084 & HD & . $\quad$ HD \\
\hline 75 & v.2.2. & - & סח & 0.0202 & ND & 0.0652 \\
\hline 78 & y.2.2 & - & SD & 0,0074 & ND & 0,0181 \\
\hline Meqai a & & $n n$ & KD & 0.0135 & ND & 0,0211 \\
\hline 82 & VI. & 0.0053 & WD & 0,0084 & 0,0020 & ND \\
\hline 85 & . VI.I & 0,0105 & ND & 0.0005 & ND & ND \\
\hline 87 & VI.1 & 0.0245 & ND & 0.0288 & ND & ND \\
\hline 20 & VI.1 & 0.0094 & No & 0.0224 & ND & ND \\
\hline Méd1a & & 0,0124 & ND & 0,0150 & 0,0005 & ND \\
\hline
\end{tabular}

ND $=$ Nào Detectāvel. 


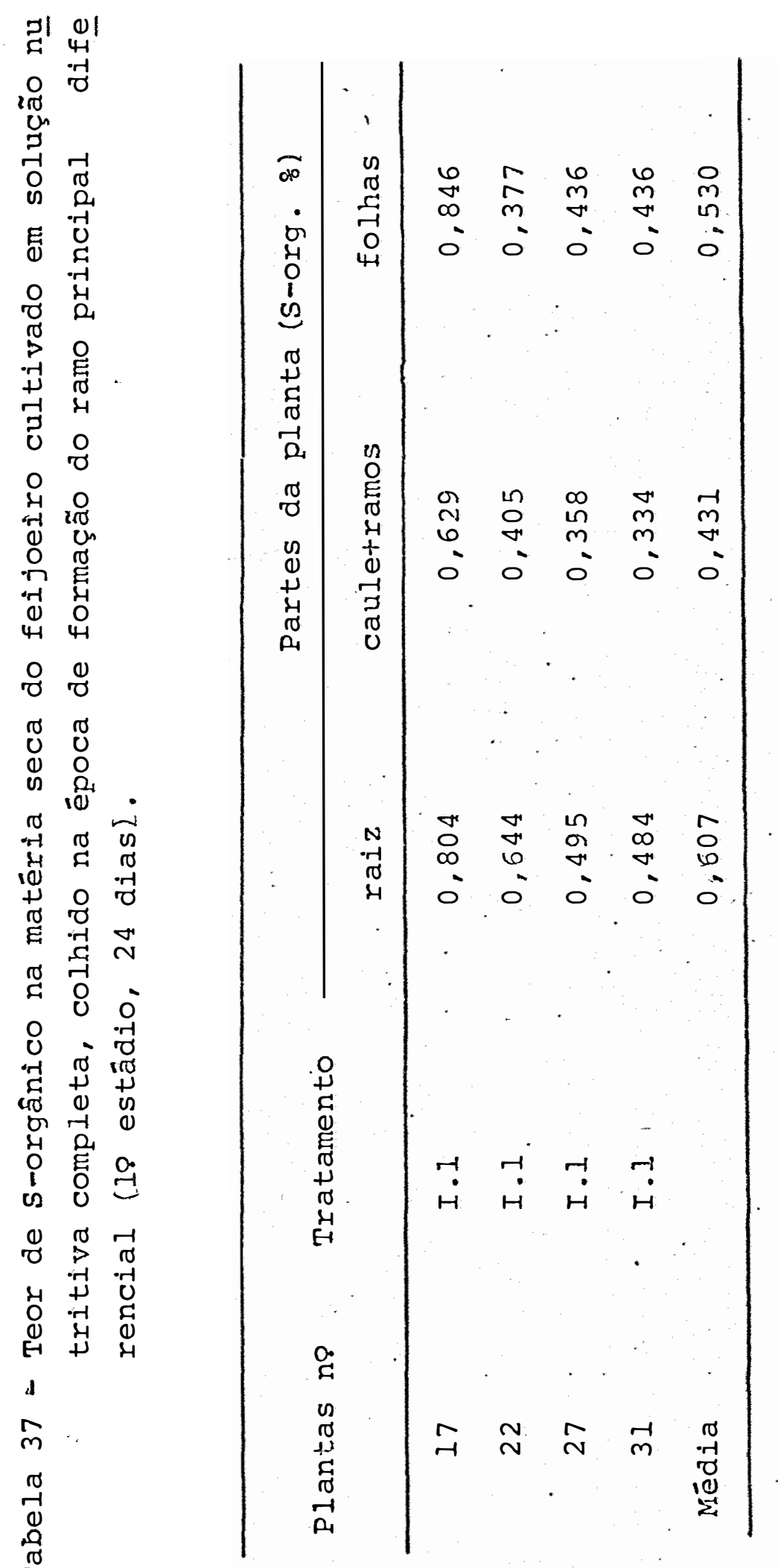




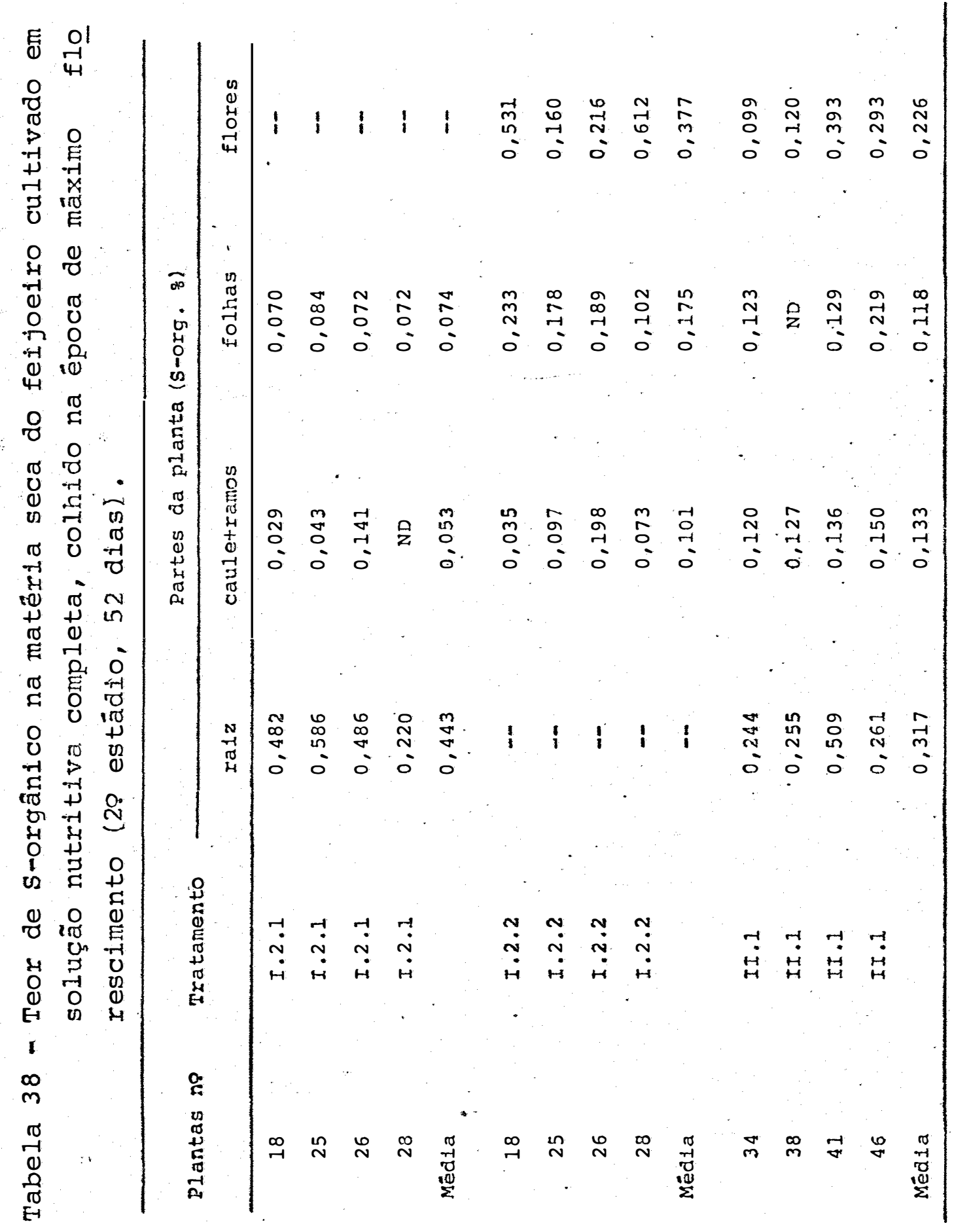


Tabela 39 - Teor de S-orgânico na matéría seca do fei joeiro cultivado em solução nutritiva con pleta, colhido na época de fim de ciclo (84 diasl.

\begin{tabular}{|c|c|c|c|c|c|c|c|c|c|}
\hline \multirow{2}{*}{ Plantas n? } & \multirow{2}{*}{ Tratumento } & \multicolumn{7}{|c|}{ Partes dis planta (s-ores. B) } & \multirow[b]{2}{*}{ gräos } \\
\hline & & rasz & & conul etramos & & folh.2s & & pericarpo & \\
\hline.$\quad 19$ & 1.3 .1 & 0,341 & & 0,053 & & 0,062 & & -- & - \\
\hline 20 & 1.3 .1 & 0,123 & & 0,028 & & 0,076 & & -- & -- \\
\hline 21 & 1.3 .1 & 0,234 & & 0,109 & & 0.058 & & - & - \\
\hline 29 & $x .3 .1$ & 0,137 & & 0,041 & & 0,040 & & $\cdots$ & - \\
\hline Média. & . & 0,209 & & 0,058 & & 0,059 & & - & . - \\
\hline 29 & 1.3 .2 & - & & 0.023 & & 0,230 & & 0,048 & 0,066 \\
\hline 20 & 1.3 .2 & - & & 0,038 & & 0,062 & & 0,050 & 0,097 \\
\hline$\therefore 21$ & 1.3 .2 & - & & 0,066 & - & 0,069 & & 0.054 & 0,057 \\
\hline 29 & $x .3 .2$ & - & & 0,053 & & 0,066 & & 0.082 & 0.063 \\
\hline Média & & - & & 0,045 & & 0,107 & & 0,058 & 0,071 \\
\hline 35 & $2 x .2 .1$ & 0,469 & & 0.030 & $\cdot$ & 0.040 & & - & - \\
\hline 39 & 11.2 .1 & 0,289 & & ND & & 0,073 & & $\cdots$ & $\cdots$ \\
\hline 12 & 21.2 .1 & 0,329 & & $.0,053$ & & 0,114 & . & - & - \\
\hline 48 & 11.2 .1 & 0,367 & . & 0,033 & & 0,068 & & $\cdots$ & $\therefore$ \\
\hline Média & & 0,363 & . & 0,029 & & 0.074 & & - & - \\
\hline 35 & 11.2 .2 & - & & 0,085 & & 0,087 & : & ND & 0,136 \\
\hline 39 & $2 x .2 .2$ & $\therefore$ & & 0,047 & & 0,071 & . & 0.046 & 0,093 \\
\hline 42 & II.2.2 & $\cdots$ & & $0.06^{\circ} 8$ & & 0,062 & & 0,048 & $0,1 \leq 0$ \\
\hline 49 & $2 x .2 .2$ & $\rightarrow$ & & 0,036 & & 0,072 & & ND & 0,131 \\
\hline Média & & + & & 0.059 & & 0.073 & & 0,023 & 0,227 \\
\hline .3 & III.X & 0,261 & & 0,029 & & 0,073 & & 0,094 & 0,141 \\
\hline$s$ & III.L & 0,372 & & 0,027 & & 0.053 & & 0,078 & 0.151 \\
\hline 9 & IIX.1 & 0.366 & & ND & & 0.062 & & 0,098 & 0,170 \\
\hline 10 & III.I & 0.289 & & 0,037 & & 0,080 & & 0.097 & 0,100 \\
\hline Mëdia & & 0,322 & & 0,023 & & 0.067 & & 0.092 & 0,140 \\
\hline
\end{tabular}

ND = são Detectável. 


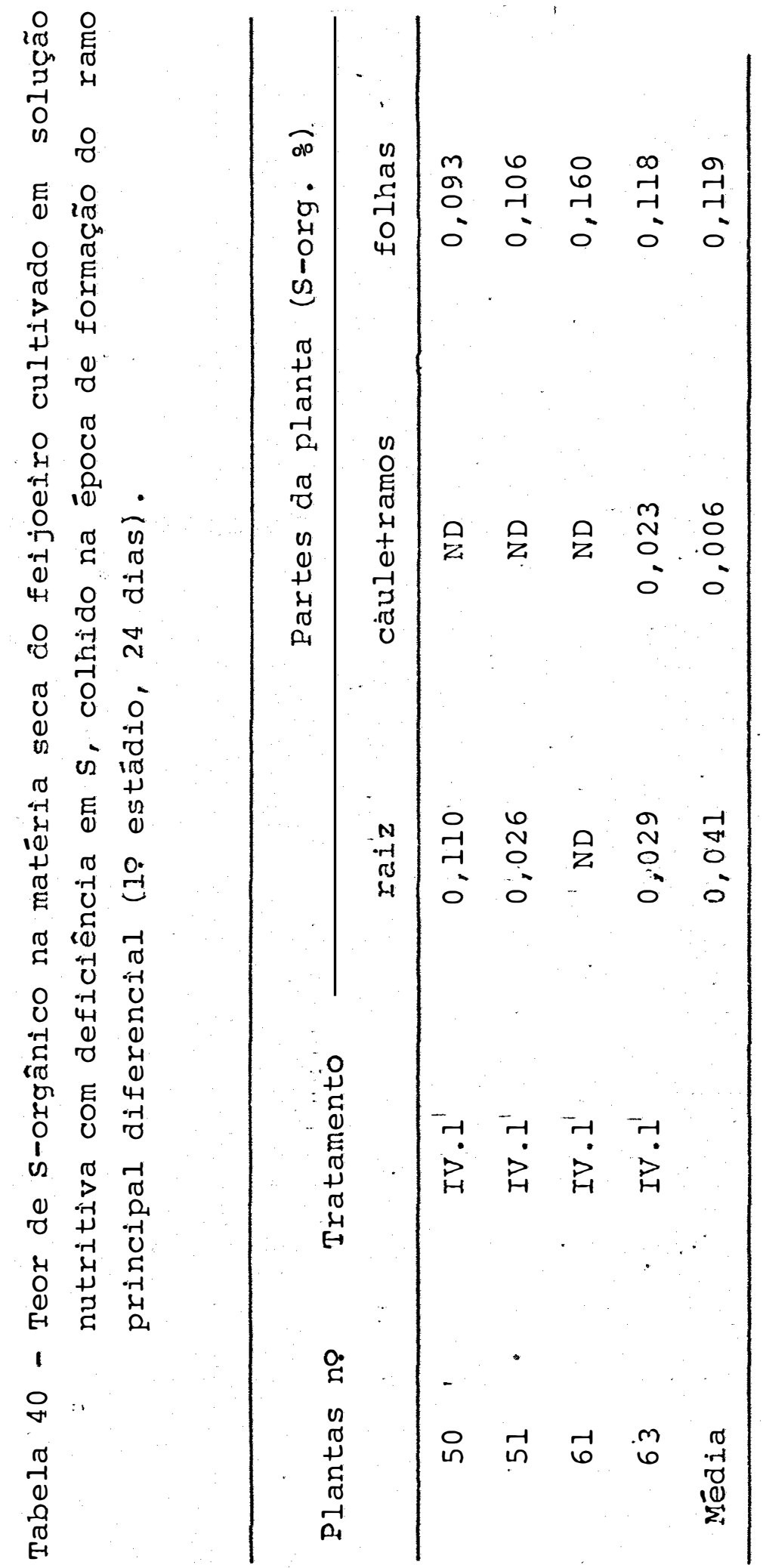


Tabela 41 - Teor de s-orgânico na matêria seca do feijoeiro cul tivado em solução nutritiva com deficiência em s, colhido na êpoca de mäximo florescimento (2: estâ dio, 52 diasl.

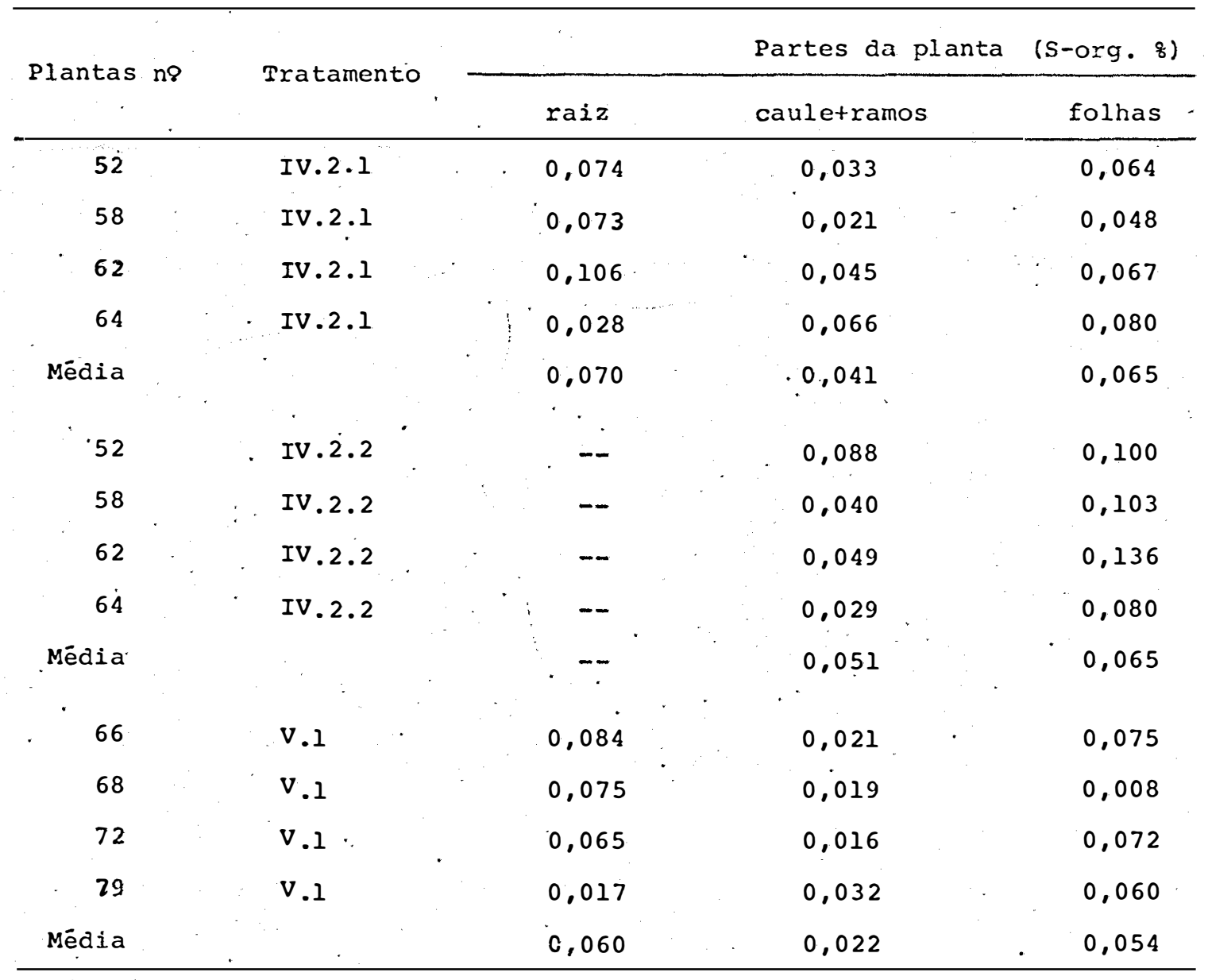


Tabela 42 - Teor de S-orgânico na matérìa seca do feijoeiro cultivado em solução nutritî va com deficiência em $S$, colhido na época de fim de ciclo (84 dias).

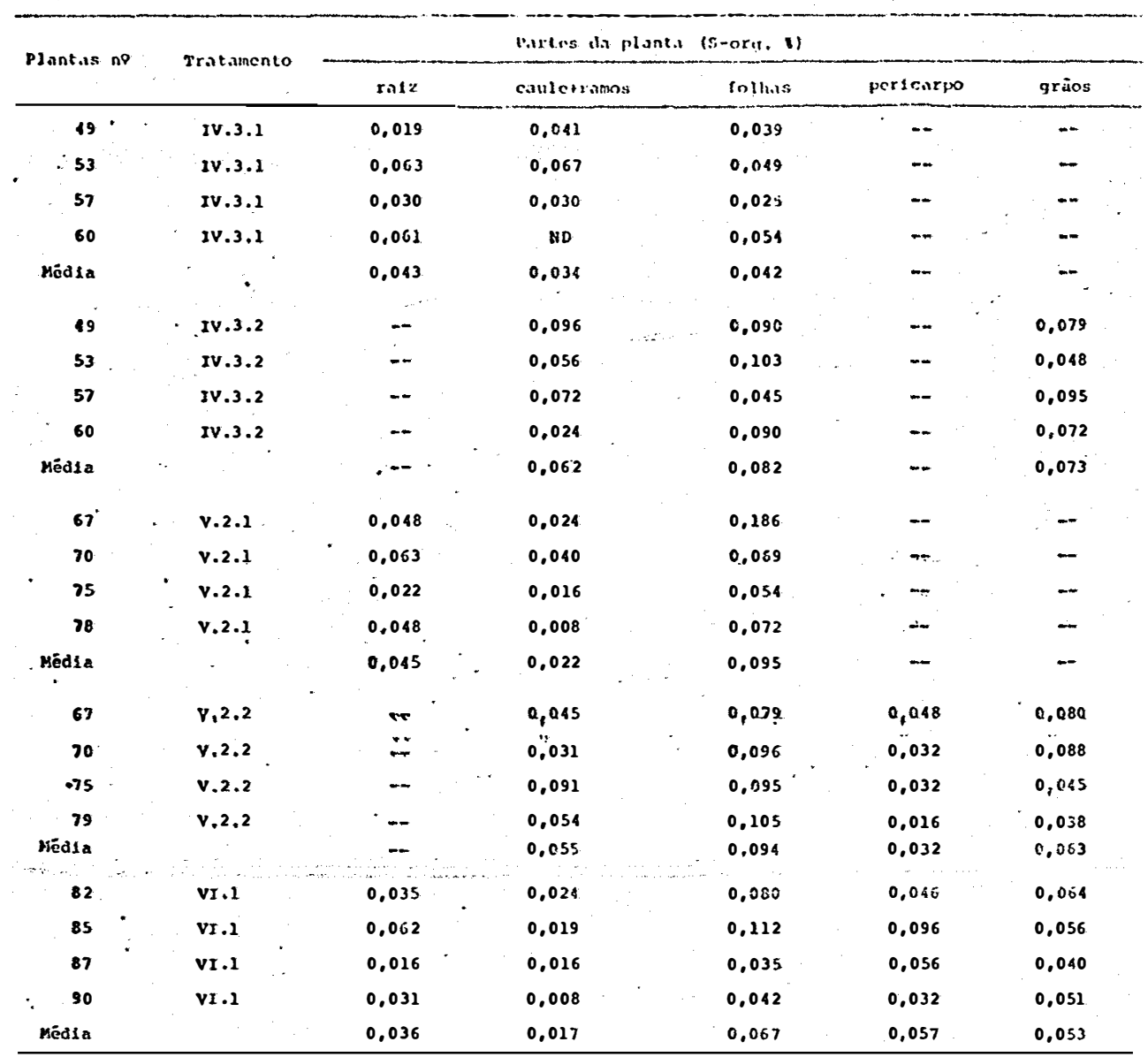

